OAK RIDGE NATIONAL LABORATORY

LOCKHEED MARTINT/7
How Do I Know?

A Guide to the Selection of

Personal Protective Equipment

for Use in Responding to

A Release of Chemical Warfare Agents

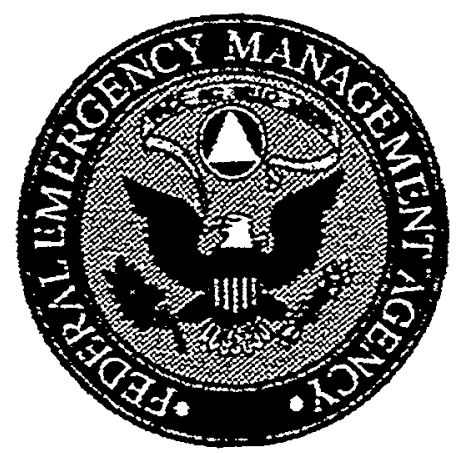

Cheri Bandy Foust

RECENED

MAY $17 \mathrm{HBO}$

OSII 
This report has been reproduced directly from the best available copy.

Available to DOE and DOE contractors from the Office of Scientific and Technical Information, P.O. Box 62, Oak Ridge, TN 37381; prices available from (423) 576-8401.

Available to the public from the National Technical Information Service, U.S. Department of Commerce, 4284 Port Royal Rd., Springfield, VA 22161.

This report was prepared as an account of work sponsored by an agency of the United States Government. Neither the United States Government nor any agency thereof, nor any of their employees, makes any warranty, expressed or implied, or assumes any legal liability or responsibility for the accuracy, completeness, or usefulness of any information, apparatus, product, or process disclosed, or represents that its use would not infringe privately owned rights. Reference herein to any specific commercial product, process, or service by trade name, trademark, manufacturer, or otherwise, does not necessarily constitute or imply its endorsement, recommendation, or favoring by the United States Government or any agency thereof. The views and opinions of the authors expressed herein do not necessarily state or reflect those of the United States Government or any agency thereof. 


\section{DISCLAIMER}

Portions of this document may be illegible in electronic image products. Images are produced from the best available original document. 


\title{
How Do I Know? \\ A Guide to the Selection of Personal Protective Equipment for Use in Responding to A Release of Chemical Warfare Agents
}

Cheri Bandy Foust

Date Published-May 1999

Prepared for the

Federal Emergency Management Agency

\author{
Prepared by \\ OAK RIDGE NATIONAL LABORATORY \\ Oak Ridge, Tennessee 37831 \\ Managed by \\ LOCKHEED MARTIN ENERGY RESEARCH CORPORATION \\ For the \\ U.S. DEPARTMENT OF ENERGY \\ under contract No. DE-AC05-96OR22464
}




\section{TABLE OF CONTENTS}

Page

TABLE OF CONTENTS $\ldots \ldots \ldots \ldots \ldots \ldots \ldots \ldots \ldots \ldots \ldots \ldots \ldots \ldots \ldots \ldots \ldots \ldots$

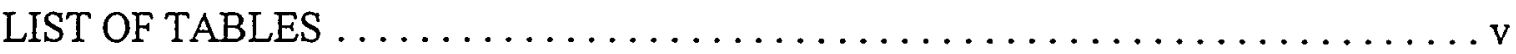

ACRONYMS AND ABBREVIATIONS $\ldots \ldots \ldots \ldots \ldots \ldots \ldots \ldots \ldots \ldots$ vii

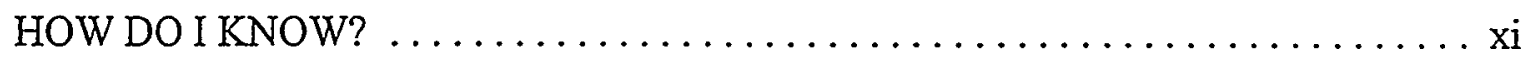

1. INFORMATION SHEET ON THE SELECTION OF

PERSONAL PROTECTIVE EQUIPMENT $\ldots \ldots \ldots \ldots \ldots \ldots \ldots \ldots \ldots \ldots .1$

2. INFORMATION SHEET ON WORKER EXPOSURE LIMITS ........... 2-1

3. INFORMATION SHEET TO AID IN THE UNDERSTANDING OF MEDICAL REQUIREMENTS FOR WORKERS WEARING

RESPIRATORY EQUIPMENT $\ldots \ldots \ldots \ldots \ldots \ldots \ldots \ldots \ldots \ldots \ldots \ldots \ldots \ldots \ldots \ldots$

4. INFORMATION SHEET-DOES 29 CFR 1910.120

APPLY TO THE CHEMICAL STOCKPILE EMERGENCY

PREPAREDNESS PROGRAM? ....................... 4 -1

5. INFORMATION SHEET TO AID IN THE SELECTION OF

THE APPROPRIATE LEVEL OF PERSONAL PROTECTIVE

EQUTPMENT IN RESPONSE TO A CHEMICAL WARFARE AGENT

ACCIDENT/INCIDENT $\ldots \ldots \ldots \ldots \ldots \ldots \ldots \ldots \ldots \ldots \ldots \ldots \ldots \ldots \ldots \ldots \ldots$

6. INFORMATION SHEET ON RESPIRATOR FILTERS,

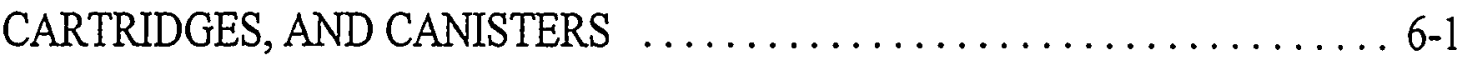

7. INFORMATION SHEET TO AID IN THE SELECTION OF APPROPRIATE RESPIRATORY EQUIPMENT $\ldots \ldots \ldots \ldots \ldots \ldots \ldots \ldots 7-1$

8. INFORMATION SHEET ON THE CHEMICAL STOCKPILE EMERGENCY PREPAREDNESS PROGRAM'S

PERSONAL PROTECTIVE CLOTHING $\ldots \ldots \ldots \ldots \ldots \ldots \ldots \ldots \ldots . \ldots .1$

8.1 BATTLEDRESS OVERGARMENT $\ldots \ldots \ldots \ldots \ldots \ldots \ldots \ldots \ldots .5$ 
8.2 RESPONDER ................................ 8-7

8.3 CHEMICAL PROTECTIVE GLOVES $\ldots \ldots \ldots \ldots \ldots \ldots \ldots \ldots \ldots . .6$

8.4 CHEMICAL PROTECTIVE HOOD . . . . . . . . . . . . . . . . 8-10

8.5 CHEMICAL PROTECTIVE OVERSHOES $\ldots \ldots \ldots \ldots \ldots \ldots \ldots \ldots .11$

8.6 CHEMICAL PROTECTIVE APRON . . . . . . . . . . . . . . . . . 8-12

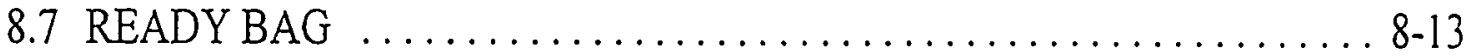

8.8 POWERED AIR-PURIFYING RESPIRATOR (PAPR) (TIGHT FITTING) $\ldots \ldots \ldots \ldots \ldots \ldots \ldots \ldots \ldots \ldots \ldots \ldots \ldots \ldots \ldots \ldots .14$

8.9 POWERED AIR-PURIFYING RESPIRATOR (PAPR) (HOODED OR LOOSE FITTING) $\ldots \ldots \ldots \ldots \ldots \ldots \ldots \ldots \ldots \ldots$ 8-16

\section{INFORMATION SHEET ON CHEMICAL AGENT}

DETECTION EQUIPMENT FOR FIELD USE $\ldots \ldots \ldots \ldots \ldots \ldots \ldots \ldots . . \ldots 9-1$

9.1 INDIVIDUAL CHEMICAL AGENT DIRECTOR (ICAD) . . . . . . . . 9-5

9.2 CHEMICAL AGENT MONTTOR (CAM) . .................. 9-6

9.3 M256 SERIES CHEMICAL AGENT DETECTOR KIT $\ldots \ldots \ldots \ldots \ldots .9 .8$

9.4 REAL TIME ANALYSIS PLATFORM (RTAP) ............... 9-10

9.5 FOX, XM93, NBC RECONNAISSANCE SYSTEM (NBCRS) . ......................... 9-11

9.6 MINIATURE CONTINUOUS AIR MONITORING SYSTEM (MINICAMS) . ......................... 9-13

9.7 AUTOMATIC CHEMICAL AGENT ALARM (ACAA) . . . . . . . . 9-15

These information sheets were prepared by Cheri Bandy Foust. She is a Research Associate at the Oak Ridge National Laboratory with a masters degree in Public Health with an emphasis in Environmental and Occupational Health and Safety. She also possesses the Certified Hazardous Materials Manager (CHMM) professional certification. 


\section{LIST OF TABLES}

Table $1.1 \quad$ Work intensities of military tasks $\ldots \ldots \ldots \ldots \ldots \ldots \ldots \ldots . .4$

Table 1.2 Number of minutes work per hour in work/rest

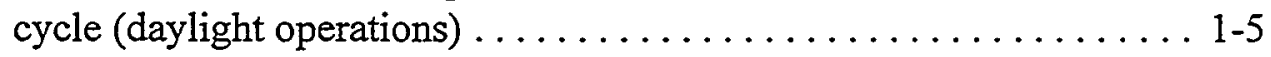

Table 2.1 CDC General population, worker exposure

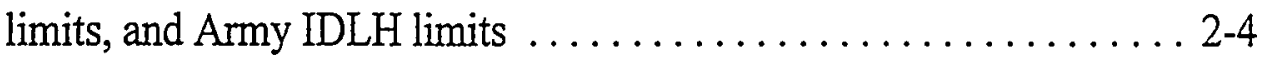

Table $2.2 \quad$ Agency Exposure Limits ....................... 2-10

Table 2.3 CDC General population, worker exposure

limits, and Army IDLH limits $\ldots \ldots \ldots \ldots \ldots \ldots \ldots \ldots .2-11$ 


\section{ABBREVIATIONS AND ACRONYMS}

ACAA

ACAMS

ACEM

ACGIH

AEGL

AIHA

ANSI

ATSDR

ASGI

ASTM

BDO

BEIs

CDC

CEGL

CFR

CPU

CSEPP

DOD

DOE

DPE

ECM

EEGL

EMP

EPA

ERPGs

ESLI

FEMA

FOX

FPD/FID

FR

GA

GB

GD

GVO

$\mathrm{H}$

HAZMAT

HAZWOPER

HD automatic chemical agent alarm

automatic continuous air monitoring systems

Automatic Continuous Environmental Monitor

American Conference of Governmental Industrial Hygienist

airborne exposure guidance levels

American Industrial Hygiene Association

American National Standards Institute

Agency for Toxic Substances and Disease Registry

radiac equipment

American Society for Testing and Materials

battledress overgarment

biological exposure indices

Centers for Disease Control and Prevention

continuous exposure guidance level

Code of Federal Regulations

chemical protective undergarment

Chemical Stockpile Emergency Preparedness Program

Department of Defense

U.S. Department of Energy

demilitarization protective ensemble

electronic counter measure

emergency exposure guidance level

electromagnetic pulse

U.S. Environmental Protection Agency

emergency response planning guidelines

end-of-service life indicator

Federal Emergency Management Agency

a fully integrated nuclear, biological, and chemical

reconnaissance system

dual detector

Federal Register

a chemical nerve agent

a chemical nerve agent

a chemical nerve agent

green vinyl overshoe

a chemical blister agent

hazardous materials

hazardous waste operations and emergency response

a chemical blister agent 


\begin{tabular}{ll} 
HEPA & high efficiency particulate air \\
HT & a chemical blister agent \\
ICAD & individual chemical agent detector \\
ICAM & improved chemical agent monitor \\
IDLH & immediately dangerous to life and health \\
kg & kilogram \\
L & lewisite (a chemical blister agent) \\
LOCs & levels of concern \\
MASH & mobile army surgical hospital \\
mg/m 3 & milligrams per cubic meter \\
MINICAMS & miniature continuous air monitoring system \\
MMAD & mass median aerodynamics diameters \\
MM1 & mobile mass spectrometer \\
MOPP & Mission Oriented Protective Posture \\
m/s & minutes per second \\
NAS & National Academy of Sciences \\
NBC & nuclear, biological, and chemical \\
NBCRC & nuclear, biological, and chemical reconnaissance system \\
NCEH & National Center for Environmental Health \\
NFPA & National Fire Protection Association \\
NIOSH & \multicolumn{1}{c}{ National Institute of Occupational Safety and Health } \\
OSHA & Occupational Safety and Health Administration \\
OV/HEPA & organic vapor/high efficiency particulate air \\
PAPR & powered air-purifying respirator \\
PEL & permissible exposure limit \\
PEL-C & permissible exposure limit-ceiling \\
PEL-STEL & permissible exposure limit-short term exposure limit \\
PEL-TWA & permissible exposure limit-time-weighted average \\
PPE & Personal Protective Equipment \\
RCRA & Resource Conservation and Recovery Act \\
REL & recommended exposure limit \\
REL-C & recommended exposure limit-ceiling \\
REL-STEL & recommended exposure limit-short term exposure limit \\
REL-TWA & recommended exposure limit-time-weighted average \\
RTAP & real time analysis platform \\
SCBA & self-contained breathing apparatus \\
SPEGL & short term public emergency guidance level \\
STEL & short term exposure limit \\
STEPO-I & self-contained toxicological environmental protective outfit- \\
& interim \\
TAPES & toxicological agent protective ensemble self-contained 1-hour \\
TLVs & threshold limit values \\
&
\end{tabular}


TREE

TSD

TWA

USACHPPM

USDOT

VOS-25

$\mathrm{VX}$

$\mathrm{XSD}$ transient radiation effects on electronics

treatment, storage and disposal

time-weighted average

U.S. Army Center for Health Promotion and Preventive Medicine U.S. Department of Transportation vehicle orientation system

a chemical nerve agent

chlorine-selective detector 


\section{HOW DO I KNOW?}

An incident involving chemical warfare agents requires a unique hazardous materials (HAZMAT) response. As with any HAZMAT event, federal regulations prescribe that responders must be protected from exposure to the chemical agents. But unlike other HAZMAT events, special considerations govern selection of personal protective equipment (PPE). PPE includes all clothing, respirators and monitoring devices used to respond to a chemical release. PPE can differ depending on whether responders are military or civilian personnel.

Traditionally, most emergency managers and responders have had little reason to become familiar with the decisions involving chemical warfare agent-related PPE. Today, however, the concern over domestic vulnerability to terrorist activities, has changed that picture. Increasingly, responders want to know how to protect themselves and others if they are faced with the need to respond to an incident involving chemical warfare agents.

Public Law 99-145 requires the U.S. Department of the Army to dispose of lethal chemical agent munition stockpiles stored at eight Army installations throughout the continental United States and Johnston Atoll in the Pacific. Recognition by the U.S. Army that the potential threat to the public from continued storage was potentially as great as the threat from transportation and the final demilitarization of chemical agents gave rise to the Chemical Stockpile Emergency Preparedness Program (CSEPP). CSEPP is a civilian community emergency preparedness program complementing the Department of Defense's initiative to destroy domestic stockpiles of aged chemical warfare munitions.

The Oak Ridge National Laboratory (ORNL) has assisted the Federal Emergency Management Agency (FEMA) in developing a wide variety of training materials for CSEPP. This document complements a CSEPP video that illustrates the testing and evaluation techniques used to assess PPE for use by CSEPP participants in the event of a chemical agent accident/incident. The video also addresses federal regulatory requirements that govern the CSEPP civilian community emergency response protocols.

Only federal requirements are discussed in the document. Readers are encouraged to check their State and local regulations in addition to Occupational Safety and Health Administration (OSHA) requirements to determine when such requirements are applicable. Because there are not specific federal regulations regarding the testing of protective clothing, industry has adopted general industry consensus standards (i.e., procedures and protocols agreed upon and upheld by industry) for testing. In addition, several nationally recognized organizations have developed procedures and protocols for testing protective clothing. Some of these organizations include the National Fire Protection Association (NFPA), the American Society for Testing and Materials 
(ASTM), and the American National Standards Institute (ANSI). However, for those organizations that may potentially respond to chemical warfare agents, it would be prudent to use the Army's testing procedures.

This publication contains a collection of information sheets dealing with PPE that were prepared for use in the CSEPP training courses. But for those unable to attend FEMA's CSEPP courses, this publication also may serve as a "stand alone" guide, saving decisionmakers time and money when questions arise concerning PPE. These information sheets attempt to answer questions such as:

- What is available?

- What are the pros and cons of making one selection versus another?

- What do items cost?

- Can more information be obtained and, if so, where?

There is a variety of protective clothing and equipment found on the market today. All PPE must meet, at a minimum, federal requirements [e.g., all respirators must be approved by the National Institute of Occupational Safety and Health (NIOSH)]. There are other pieces of protective clothing and equipment not identified in these information sheets that would be appropriate for use with chemical agents. The protective clothing and equipment discussed in these information sheets represent PPE appropriate for CSEPP participants, based on CSEPP's concept of operations, equipment testing, work rules, and tasks to be performed.

FEMA is grateful to the many individuals in the public and private sectors who contributed their time and expertise to ensure the accuracy of these information sheets. Suggestions for additions to this collection, as well as general inquires and comments about FEMA's assistance in the matter of chemical warfare agents, are encouraged. Please send them to FEMA's Regulatory Services Coordination Unit (ATTN: CSEPP Training) at $500 \mathrm{C}$ Street, S.W., Washington, D.C. 20472. Further information about FEMA's full collection of training materials, including the CSEPP courses, may be obtained by contacting FEMA's Division of Training at 16825 South Seton Avenue, Emmitsburg, Maryland 21727.

Technical questions regarding the equipment included in this document, and requests for identification of sources through which the items may be obtained, should be directed to:

Commander, U.S. Army Soldier and Biological Chemical Command Project Manager for Chemical Stockpile Emergency Preparedness

Attention: SSBOE-CS

5183 Blackhawk Road

Aberdeen Proving Ground, Maryland 21010-5423 


\section{TECHNICAL REVIEWERS}

U.S. Army

Wyett Colclauser

CSEPP Core Team

Rob Weiss

CSEPP Core Team

Barry Willmington

Chief, Chemical Training Department

Federal Emergency Management Agency

Robert Norville

Project Director, CSEPP Technical Training

Karen Cleveland

Emergency Management Program Specialist

Don Cornell

Emergency Management Program Specialist

David Thomas

Emergency Management Program Specialist

\section{State/Local Organizations}

Rick Bearden HAZMAT Training Officer

Joe Bell

CSEPP Exercise and Training Officer

Robert (Butch) Swenson

Assistant Fire Chief

\section{Federal Laboratories}

Paul Roberts

Emergency Management Specialist

Dr. John Sorensen

CSEPP Program Manager

Dr. Kathy Gant

Dr. Annetta Watson

Private Companies

Jack Sawicki

Director, Business Development

Barry Shumpert

Research Associate

Kathy Opolka

Product Manager, Chemical Products

Dr. Gary Sides

Bob Head

Government Accounts Manager

David Pike

Director, Racal Filter Technologies

Greg Stalnaker

Product Manager, SCBA and Supplied Air

Marc Burton

Product Manager, Powered Air Purifying
US Army Soldier and Biological Chemical Command

US Army Soldier and Biological

Chemical Command

US Army Defense Ammunition

Center

FEMA HQS

FEMA HQS

FEMA Region IV

FEMA Region IV

Alabama (Gadsden Fire Dept.)

Indiana (State Emergency Management Agency)

Utah (Salt Lake County)

\author{
Argonne National Laboratory \\ Oak Ridge National Laboratory \\ Oak Ridge National Laboratory \\ Oak Ridge National Laboratory
}

GEOMET Technologies, Inc.

University of Tennessee

Kappler, USA

Southern Research Institute

3M Racal

3M Racal

3M Racal

3M Racal 


\section{INFORMATION SHEET ON THE SELECTION OF PERSONAL PROTECTIVE EQUIPMENT (PPE)}

\section{Who is the Intended Audience?}

The intended audience for this information sheet are those individuals who may participate in the selection of appropriate PPE, and workers who need to increase their basic knowledge and understanding of the selection process. As this information sheet is intended as an overview of a complex subject, users are encouraged to consult the references cited herein for additional assistance.

\section{When Do I Need PPE?}

According to the Occupational Safety and Health Administration's (OSHA) Personal Protective Equipment General Requirements [29 Code of Federal Regulations (CFR) 1910.132], "... (PPE) shall be provided (to employees), used, and maintained in a sanitary and reliable condition wherever it is necessary by reason of hazards of processes or environment, chemical hazards, radiological hazards, or mechanical irritants encountered in a manner capable of causing injury or impairment in the function of any part of the body through absorption, inhalation or physical contact."

Activities which involve hazardous materials, whether routine plant activities, laboratorytype activities, or emergencies, will require the use of PPE to prevent harmful exposures of chemicals from contacting. and damaging skin tissue, being absorbed through the skin, or being inhaled, ingested, or injected.

Subpart I-Personal Protective Equipment [29 CFR 1910.132-1910.138] covers general PPE requirements, eye and face protection, respiratory protection, head protection, foot protection, electrical protective equipment, and hand protection. However, because there are no specific federal regulations regarding the testing of protective clothing, industry has adopted voluntary industry-wide consensus standards (i.e., procedures and protocols agreed upon and upheld by industry) for testing protective clothing. Several nationally recognized organizations that have developed testing procedures and protocols include the National Fire Protection Association (NFPA), the American Society for Testing and Materials (ASTM), and the American National Standards Institute (ANSI). However, if an organization may potentially respond to chemical warfare agents, the testing procedures developed by the U.S. Army would be prudent to use. 


\section{What Type of Information Do I Need to Start The Selection Process?}

Consideration needs to be given to the phrases harmful and potentially harmful concentrations of hazardous materials and level of PPE. To control for exposure to hazardous materials and thereby ensure protection of workers, an organization must establish work rules. One of the fundamental decisions will be the type of activities to be performed by this organization. If workers are to perform daily, routine job activities, the organization may select such exposure limits as the American Conference of Governmental Industrial Hygienist's (ACGIH) 8-hour time-weighted average (TWA) limits. However, if workers are performing emergency response activities, guidelines such as the American Industrial Hygiene Associations's (AIHA) emergency response planning guidelines (ERPGs) exposure limits may be more appropriate. Work rules also play a key role when selecting the appropriate level of PPE. Workers need to know the type of environment in which they will be working. For example, if an organization will be performing emergency response work, it is important that workers know the appropriate level of PPE to wear in an immediately dangerous to life and health (IDLH) environment or an unknown environment. An unknown environment is any environment where the contaminant is not known and/or an environment without an established level of concentration.

Wearing any respirator, alone or in conjunction with other types of protective equipment. will impose some physiological stress on the wearer. Heat stress is a serious consideration for workers wearing chemical protective clothing and respirators. Whenever protective clothing and equipment are used, guidelines for reducing heat stress should be followed. Body temperature must be maintained within narrow limits for optimum physical and mental performance. The body produces more heat during work than rest. Normally, the body cools itself by evaporation of sweat and radiation of heat at the skin's surface. PPE restricts these heat loss mechanisms because of its high insulation and low permeability to water vapor. In addition, physical work tasks require more effort when workers wear protective clothing because of added weight and restricted movement. This results in more body heat to be dissipated than normal and a faster rise in body temperature. The amount of heat accumulation depends upon:

- the amount of physical activity,

- the level of hydration,

- the clothing worn,

- the load carried,

- the state of heat acclimatization, physical fitness and fatigue, and

- terrain and climatic conditions. 
Adaptation of the military's Mission Oriented Protective Posture (MOPP) levels is a concept that an organization might want to consider for use. MOPP levels are used in order to help reduce heat buildup and to improve individual job performance. For example, when there is a "threat" of contamination, the On-Scene Commander may order MOPP Zero. MOPP Zero includes carrying or storing PPE within arms reach (e.g., within the work area or vehicle). MOPP PPE includes protective clothing and respirators. Workers in MOPP Zero would automatically upgrade to MOPP 1 when it is determined, or when responders are notified, that chemical weapons agents have been used or that the threat for use has risen. MOPP 4 would include donning (and securing) all protective clothing, gloves, boots, hood, and respirator. For more detailed information, please refer to the U.S. Army's Field Manual 3-4, NBC Protection.

Work intensity is a major contributing factor to heat stress. Military work can be categorized as very light, light, moderate, or heavy. Tables 1-1 and 1-2 provide examples taken from $N B C$ Protection that can be used as a guide in estimating the work intensity for a particular task and calculating work/rest cycles for various environmental conditions, clothing levels, and work intensities during daylight operations. These guidelines should not be used as a substitute for common sense or experience. Individual requirements may vary greatly. The appearance of heat casualties is evidence that the selected work/rest schedule is inappropriate for the conditions.

For more information concerning heat stress, please refer to the ACGIH's 1997 Threshold Limit Values for Chemical Substances and Physical Agents and Biological Exposure Indices (BEIs), or the National Institute of Occupational Safety and Health's (NIOSH) Criteria for a Recommended Standard-Occupational Exposure to Hot Environments.

A brief description of OSHA's levels of protection and the appropriate time to wear PPE is listed below. If an organization may potentially respond to chemical warfare agents such as nerve or blister agents, please refer to the U.S. Army's Chemical Agent Safety Program and Toxic Chemical Agent Safety Standards along with 29 CFR 1910.120 Hazardous Waste Operations and Emergency Response (HAZWOPER) Standard, Appendix B-General Description and Discussion of the Levels of Protection and Protective Gear.

According to 29 CFR 1910.120 Appendix B, the levels of protection for responders are:

- OSHA Level A. To be selected when the greatest level of skin, respiratory, and eye protection is required. 
Table 1-1. Work intensities of military tasks

\begin{tabular}{|c|c|c|}
\hline $\begin{array}{l}\text { Work intensity in } \\
\text { MOPP 0-1 }\end{array}$ & Activity & $\begin{array}{l}\text { Work intensity in } \\
\text { MOPP 2-4 }\end{array}$ \\
\hline VERY LIGHT & $\begin{array}{l}\text { Lying on Ground } \\
\text { Standing in Foxhole } \\
\text { Sitting in Truck } \\
\text { Guard Duty } \\
\text { Driving Truck }\end{array}$ & VERY LIGHT \\
\hline LIGHT & $\begin{array}{l}\text { Cleaning Rifle } \\
\text { Walking Hard Surface/ } \\
1 \mathrm{~m} / \mathrm{s} \text { No Load } \\
\text { Walking Hard Surface/ } \\
1 \mathrm{~m} / \mathrm{s} 20 \mathrm{~kg} \text { Load } \\
\text { Manual of Arms } \\
\text { Walking Hard Surface/ } \\
1 \mathrm{~m} / \mathrm{s} 30 \mathrm{~kg} \text { Load }\end{array}$ & LIGHT \\
\hline & $\begin{array}{l}\text { Walking Loose Sand/ } \\
1 \mathrm{~m} / \mathrm{s} \text { No Load } \\
\text { Walking Hard Surface/ } \\
1.56 \mathrm{~m} / \mathrm{s} \text { No Load } \\
\text { Calisthenics }\end{array}$ & MODERATE \\
\hline MODERATE & $\begin{array}{l}\text { Walking Hard Surface/ } \\
1.56 \mathrm{~m} / \mathrm{s} 20 \mathrm{~kg} \text { Load } \\
\text { Scouting Patrol } \\
\text { Pick and Shovel } \\
\text { Crawling Full Pack } \\
\text { Foxhole Digging } \\
\text { Field Assaults }\end{array}$ & HEAVY \\
\hline HEAVY & $\begin{array}{c}\text { Walking Hard Surface/ } \\
1.56 \mathrm{~m} / \mathrm{s} 30 \mathrm{~kg} \text { Load } \\
\text { Walking Hard Surface/ } \\
2.0 \mathrm{~m} / \mathrm{s} \text { No Load } \\
\text { Emplacement Digging } \\
\text { Walking Hard Surface/ } \\
2.25 \mathrm{~m} / \mathrm{s} \text { No Load } \\
\text { Walking Loose Sand } \\
1.56 \mathrm{~m} / \mathrm{s} \text { No Load }\end{array}$ & $\begin{array}{l}\text { The work intensity categories of } \\
\text { this table are based on metabolic } \\
\text { expenditures. } \\
\text { Very Light }=105 \text { to } 175 \text { watts } \\
\text { Light }=172 \text { to } 325 \text { watts } \\
\text { Moderate }=325 \text { to } 500 \text { watts } \\
\text { Heavy }=500+\text { watts } \\
\text { The weight of the chemical } \\
\text { protective overboots is a primary } \\
\text { contributor to increased work } \\
\text { intensity in MOPP. }\end{array}$ \\
\hline
\end{tabular}


Table 1-2. Number of minutes work per hour in work/rest cycle (daylight operations)

\begin{tabular}{|c|c|c|c|c|c|c|c|c|c|}
\hline & & \multicolumn{4}{|c|}{ MOPP zero } & \multicolumn{4}{|c|}{ MOPP4 \& underwear } \\
\hline WBGT & Ta & VL & $\mathrm{L}$ & M & $\mathrm{H}$ & VL & $\mathrm{L}$ & M & $\mathrm{H}$ \\
\hline 78 & 82 & \multirow{11}{*}{ NL } & \multirow{8}{*}{ NL } & NL & 25 & \multirow{9}{*}{ NL } & 30 & 10 & 5 \\
\hline 80 & 84 & & & 40 & 25 & & 25 & 10 & \multirow{11}{*}{ na } \\
\hline 82 & 87 & & & 35 & 20 & & 20 & 5 & \\
\hline 84 & 89 & & & 30 & 20 & & \multirow{9}{*}{ na } & \multirow{9}{*}{ na } & \\
\hline 86 & 91 & & & 30 & 20 & & & & \\
\hline 88 & 94 & & & 20 & 15 & & & & \\
\hline 90 & 96 & & & 20 & 10 & & & & \\
\hline 92 & 98 & & & 10 & 10 & & & & \\
\hline 94 & 100 & & 30 & 10 & 10 & & & & \\
\hline 96 & 103 & & 10 & \multirow{3}{*}{ na } & \multirow{3}{*}{ na } & \multirow{3}{*}{ na } & & & \\
\hline 98 & 105 & & \multirow{2}{*}{ na } & & & & & & \\
\hline 100 & 107 & na & & & & & & & \\
\hline \multicolumn{5}{|c|}{$\begin{array}{l}\text { KEY TO TABLE } \\
\text { WBGT - Wet Bulb Globe } \\
\text { Temperature }\left({ }^{\circ} \mathrm{F}\right) \\
\left.\text { Ta - Ambient Temperature (Dry Bulb - }{ }^{\circ} \mathrm{F}\right) \\
\text { VL - Very Light Work Intensity } \\
\text { L- Light Work Intensity } \\
\text { M - Moderate Work Intensity } \\
\text { H - Heavy Work Intensity } \\
\text { NL - No Limit (Continuous Work Possible) } \\
\text { na - Work/Rest Cycle Not Feasible }\end{array}$} & \multicolumn{5}{|c|}{$\begin{array}{l}\text { INSTRUCTIONS AND NOTES } \\
\text { This table provides, for four levels of work } \\
\text { intensity, the number of minutes of work per } \\
\text { hour in work/rest schedules tailored to the } \\
\text { conditions specified. The remainder of each } \\
\text { hour should be spent in rest. This table was } \\
\text { prepared using the prediction capability of the } \\
\text { USARIEM Heat Strain Model. Assumptions } \\
\text { used in generating this table include } 1 \text { ) troops } \\
\text { fully hydrated, rested, and acclimatized; } 2 \text { ) } 50 \% \\
\text { relative humidity; } 3 \text { ) windspeed }=2 \mathrm{~m} / \mathrm{s} ; \\
\text { 4) clear skies; 5) heat casualties <5\%. This } \\
\text { guide should not be used as a substitute for } \\
\text { common sense or experience. Individual } \\
\text { requirements may very greatly. The appearance } \\
\text { of heat casualties is evidence that the selected } \\
\text { work/rest schedule is inappropriate for the } \\
\text { conditions. USARIEM } 1 / 11 / 91 \text {. }\end{array}$} \\
\hline
\end{tabular}


Appropriate equipment would include (1) a positive pressure, full facepiece selfcontained breathing apparatus (SCBA), or a positive pressure, supplied air respirator with escape SCBA (approved by NIOSH), (2) a totally-encapsulating chemical protective suit with chemical resistant inner and outer gloves, and (3) chemical resistant boots with steel toe and shank.

- OSHA Level B. To be selected when the highest level of respiratory protection is necessary, but a lesser level of skin protection is needed.

Appropriate equipment would include (1) a positive pressure, full facepiece SCBA, or a positive pressure, supplied air respirator with escape SCBA (approved by NIOSH), (2) hooded chemical resistant clothing (one or two piece chemical splash suit), (3) chemical resistant inner and outer gloves, and (4) chemical resistant boots with steel toe and shank.

- OSHA Level C. To be selected when the concentration(s) and type(s) of airborne substance(s) are known and the criteria for using air purifying respirators are met. Air purifying respirators are limited in their use to those environments where there is sufficient oxygen to sustain life and the air contaminant level is within the specified concentration limitation of the device. Please refer to the user's manual for specific instructions outlining appropriate use and limitations.

Appropriate equipment would include (1) a full-face or half-mask air purifying respirator (approved by NIOSH), (2) hooded chemical resistant clothing (one or two piece chemical splash suits), (3) chemical resistant inner and outer gloves, and (4) chemical resistant boots with steel toe and shank.

- OSHA Level D. To be selected when a work uniform is needed that will afford minimal protection; used for nuisance contamination only.

Appropriate equipment would include coveralls, gloves, chemical resistant steel toe and shank boots, and safety glasses or chemical splash goggles.

\section{- Appropriate Level of Protection for Individuals Performing Decontamination.}

According to OSHA's Inspection Procedures Manual for the HAZWOPER Standard, 29 CFR 1910.120 (q), workers performing decontamination activities should wear PPE at the same level or one level below the emergency responders they are supporting. 
The preliminary site characterization and/or the preliminary survey conducted at hazardous waste sites (or following a chemical warfare agent release) will help identify what might be encountered, as well as the conditions existing at other locations staffed by community emergency responders (e.g., traffic control points and decontamination and medical treatment stations). This analysis will yield or allow specification of certain pieces of key information that must be obtained before any PPE can be selected. These essential data include:

- contaminant(s),

- concentration(s) or potential concentrations,

- physical and chemical properties of contaminants,

- physiological effects on the body,

- harmful concentration levels,

- IDLH conditions,

- potential skin absorption and irritation sources,

- potential eye irritation sources,

- explosive sensitivity and flammability ranges,

- $\quad$ physical hazards particular to the site,

- $\quad$ engineering controls in use,

- nature of tasks to be performed,

- duration of work, and

- climatic conditions.

In the selection and use of PPE there are some constants. For example, following the decision logic of 29 CFR 1910.120 and 29 CFR 1910.134:

- Any entry into an unknown or IDLH atmosphere requires Level A protection. Downgrading from this level must be based upon objective sampling data showing it is safe to do so.

- If IDLH conditions are encountered, if less than $19.5 \%$ oxygen is suspected, or if contaminants have poor warning properties, a SCBA respirator, or a supplied air respirator with an escape bottle must be used.

- Level A protection must be used if an IDLH condition can result from skin contact.

\section{Where Can I Go for More Information?}

More detailed information to aid in the selection of PPE can be obtained from sources such as those listed below. 
ACGIH (American Conference of Governmental Industrial Hygienists), 1997. Threshold Limit Values (TLVS) for Chemical Substances and Physical Agents and Biological Exposure Indices (BEIs), Cincinnati: American Conference of Governmental Industrial Hygienists.

ANSI (American National Standards Institute), American National Standard for Respiratory Protection, ANSI Z88.2-1992, New York.

CFR, Title 29, Part 1910.120 Hazardous Waste Operations and Emergency Response (HAZWOPER) Standard.

CFR, Title 29, Part 1910.120 HAZWOPER Standard, Appendix A - Personal Protective Equipment Test Methods.

CFR, Title 29, Part 1910.120 HAZWOPER Standard, Appendix B - General Description and Discussion of the Levels of Protection and Protective Gear.

CFR, Title 29, Part 1910.120 HAZWOPER Standard, Appendix C - Compliance Guidelines.

CFR, Title 29, Subpart I - Personal Protective Equipment, 1910.132 through 1910.138.

Department of the Army, AR 385-61, Chemical Agent Safety Program, February 1997, . Office of the Chief of Staff, Washington, DC.

Department of the Army, NBC Protection, FM-3-4, Headquarters, Washington, DC.

Department of the Army, DA PAM 385-61, Toxic Chemical Agent Safety Standards, March 1997, Office of the Chief of Staff, Washington, DC.

NIOSH (National Institute for Occupational Safety and Health). Criteria for a Recommended Standard-Occupational Exposure to Hot Environments, Department of Health and Human Services, (NIOSH) Publication No. 86-113, April 1986. 
Also included are World Wide Web homepage addresses for various regulatory and other accepted industry wide organizations.

\begin{tabular}{ll}
\hline Agency & WWW Address \\
\hline & \\
Agency for Toxic Substances & \\
and Disease Registry & \\
(ATSDR) & http://atsdrl.atsdr.cdc.gov:8080/atsdrhome.html \\
ACGIH & http://acgih.org/ \\
AIHA & http://www.aiha.org/ \\
ANSI & http://www.ansi.org/ \\
Centers for Disease Control and & \\
Prevention (CDC) & http://www.cdc.gov/ \\
CFR & http://www.access.gpo.gov/nara/cfr-table-search.html \\
Environmental Protection & \\
Agency (EPA) & http://www.epa.gov/ \\
FEMA & http://www.fema.gov/ \\
NFPA & http://www.nfpa.org/ \\
NIOSH & http://www.cdc.gov/niosh/homepage.html \\
OSHA & http://www.osha.gov/ \\
U.S. Army Edgewood Research & \\
Development and Engineering & http://www.cbdcom.apgea.army.mil/RDA/erdec/risk/ \\
Center (ERDEC) & safety/index.html
\end{tabular}




\section{INFORMATION SHEET ON WORKER EXPOSURE LIMITS}

\section{Who is the Intended Audience?}

The intended audience for this information sheet are those individuals who may participate in the selection of appropriate personal protective equipment (PPE). This document can also be used by workers who will be wearing PPE and need to increase their basic knowledge and understanding of worker exposure limits. As this information sheet is intended as an overview of a complex subject, users are encouraged to consult the references cited herein for additional assistance.

\section{Concept of Operations and Work Rules}

Each organization must establish and define its purpose or mission (i.e., the reason for the organization's existence). Once the mission is defined, specific job duties and the procedures to accomplish these job duties must be determined. An organization must also establish work rules in order to protect the workers. One of the fundamental decisions will be the type of activities to be performed. If workers are to perform daily, routine job activities, the organization may select such exposure limits as the American Conference of Governmental Industrial Hygienist's (ACGIH) 8-hour time-weighted average (TWA) threshold limit values (TLVs). However, if workers are performing emergency response activities, guidelines such as the American Industrial Hygiene Association's (AIHA) emergency response planning guidelines (ERPGs) exposure limits may be more appropriate. These guidelines may be more appropriate because they were established for exposures at high levels of short duration that occur once in a lifetime. Work rules also play a key role when selecting the appropriate level of PPE. Workers need to know the type of environment in which they will be working. The description below is an example of an organization's concept of operations and work rules.

\section{Chemical Stockpile Emergency Preparedness Program (CSEPP) Concept} of Operations

CSEPP is a community emergency preparedness program complementing the Department of Defense's initiative to destroy domestic stockpiles of aged chemical warfare agents. CSEPP has established a concept of operations and work rules for CSEPP participants which govern response to an accident/incident involving a release of chemical warfare agents on one of the eight military installations storing the agents in the continental U.S.

The military installations have hazardous materials (HAZMAT) teams trained and equipped to respond to any accident/incident on the military 
installation (i.e., on-site or on-post). CSEPP response actions will be limited to actions off the military installation (i.e., off-site or off-post) that protect the civilian general population or public. CSEPP participants involved in the off-post response will perform a limited variety of functions, including controlling evacuation traffic, providing emergency medical services, and performing emergency decontamination. Although contact with off-post areas potentially contaminated with chemical agent is to be avoided where possible, assignments within such areas may be necessary to protect the public. To provide protection in the event of entry into contaminated areas, participants identified in CSEPP emergency response plans will be issued PPE appropriate for the situation.

\section{CSEPP Work Rules}

Work rules were established to ensure CSEPP off-post participants will not be deployed into areas known or suspected to be contaminated, until such time as Army-performed monitoring and field sampling confirms that the level of contamination is within the range for which PPE provides protection. Work rules prohibit CSEPP participants from:

- being sent into known or suspected IDLH environments,

- being sent into areas where the airborne concentration is known or suspected to exceed the protective capacity of the powered air-purifying respirator (PAPR),

- remaining in a potentially contaminated area long enough to receive an agent dosage in excess of that corresponding to the airborne exposure limit [i.e., the threshold limit value (TLV)] for agent workers,

- remaining in a potentially contaminated area long enough to exceed the agent absorption capacity of the canisters used in the PAPR, and

- being exposed to agent deposition density levels exceeding the maximum capability of the approved protective clothing [e.g., battledress overgarment (BDO) or Responder chemical protective suit].

In addition, respirators must only be used by CSEPP participants in the context of a complete respirator program as described in applicable OSHA regulations. 


\section{Worker Exposure Limits}

In order for an organization to establish work rules to control for exposure to hazardous materials, the appropriate category of worker exposure limits must be selected. Listed below are the definitions of the different categories of worker exposure limits. The exposure limits (as of 1999) for chemical warfare agents are also listed.

\section{Threshold Limits Values (TLVS) - 8 Hour TWA}

The ACGIH TLVs, OSHA's permissible exposure limits (PELs), and the National Institute of Occupational Safety and Health's (NIOSH) recommended exposure limits (RELs) were established for hazardous substances found in the workplace. These limits refer to airborne concentrations of substances and represent conditions under which it is believed that nearly all workers may be repeatedly exposed day after day without adverse effect. Definitions of different worker exposure limits and emergency response exposure guidelines are contained in Appendix A - Definitions.

When the need for chemical agent worker exposure limits arose in the face of plans to destroy chemical warfare agents, the Centers for Disease Control and Prevention (CDC) published general population and agent worker airborne exposure limits in the Federal Register, Tuesday, March 15, 1988, Vol. 53, No. 50.

\section{IDLH Exposure Limits}

\section{NIOSH defines IDLH as:}

The maximum concentration from which, in the event of respirator failure, a healthy male worker could escape within 30 minutes without a respirator and without experiencing any escape-impairing (e.g., severe eye irritation) or irreversible health effects.

IDLH guidelines were developed for respirator selection purposes, not for setting permissible exposure limits. IDLH guidelines are based upon the response of a healthy, male worker population and do not take into account exposure of more sensitive individuals such as the elderly, children, or people with various health problems. Also, the IDLH is based on a maximum 30-minute exposure period, which may not be realistic for accidental airborne releases.

IDLHs are concentrations above which a highly reliable breathing apparatus is required for escape [e.g., a self-contained breathing apparatus (SCBA)]. NIOSH is responsible for establishing IDLH exposure limits for certain toxic and hazardous substances. NIOSH has been tasked by OSHA to do so. 
As chemical warfare agents have traditionally been used by the military, and not found in the workplace, there were no NIOSH-established IDLH limits for these agents. In the absence of NIOSH-established IDLH limits for chemical warfare agents, the U.S. Army Surgeon General established IDLH limits for military use in 1992. These IDLH limits were based on recommendations from the U.S. Army Environmental Hygiene Agency and are to be used for the purpose of establishing the concentrations at which SCBAs or supplied air respirators are required by military personnel. The CDC's general population and agent worker exposure limits and the Army's IDLH exposure limits are shown below.

Taḅle 2.1. CDC general population, worker exposure limits, and army IDLH limits

\begin{tabular}{|c|c|c|c|}
\hline Agent & $\begin{array}{c}\text { CDC } \\
\text { General Population } \\
\text { Airborne Exposure } \\
\text { Limits }\end{array}$ & $\begin{array}{c}\text { CDC } \\
\text { Agent Worker } \\
\text { Airborne Exposure } \\
\text { Limits }\end{array}$ & $\begin{array}{l}\text { U.S. Army } \\
\text { IDLH Airborne } \\
\text { Exposure Limits }\end{array}$ \\
\hline GA, GB & $0.0000003 \mathrm{mg} / \mathrm{m}^{3}$ & $0.0001 \mathrm{mg} / \mathrm{m}^{3}$ & $0.2 \mathrm{mg} / \mathrm{m}^{3}$ \\
\hline VX & $0.000003 \mathrm{mg} / \mathrm{m}^{3}$ & $0.0001 \mathrm{mg} / \mathrm{m}^{3}$ & $0.02 \mathrm{mg} / \mathrm{m}^{3}$ \\
\hline $\mathrm{H}, \mathrm{HD}, \mathrm{HT}$ & $0.0001 \mathrm{mg} / \mathrm{m}^{3}$ & $0.003 \mathrm{mg} / \mathrm{m}^{3}$ & $0.003 \mathrm{mg} / \mathrm{m}^{3}$ \\
\hline L & $0.003 \mathrm{mg} / \mathrm{m}^{3}$ & $0.003 \mathrm{mg} / \mathrm{m}^{3}$ & $0.003 \mathrm{mg} / \mathrm{m}^{3}$ \\
\hline $\begin{array}{l}\text { Averaging } \\
\text { Time }\end{array}$ & 72 Hours & 8 Hours & 30 Minutes \\
\hline
\end{tabular}

\section{Emergency Response Exposure Guidelines}

Traditional TLV-TWA exposure limits are not applicable when work involves emergency response efforts. Emergency response workers need exposure limits for exposure at high levels of short duration that occur once in a lifetime.

There are no exposure limits established by OSHA for emergency response workers. In recognition of this need, emergency response exposure guidelines have been developed by several nationally recognized agencies for some extremely hazardous substances. An organization should be familiar with the different exposure guidelines established, and choose the guideline appropriate for the work to be performed, the hazardous substance(s) involved, and the group potentially exposed (e.g., emergency response workers, general public, etc).

The AIHA developed emergency response planning guidelines (ERPGs) for emergency response purposes. The Department of Energy (DOE) uses the AIHA ERPGs as the primary chemical exposure criteria for DOE emergency planning and preparedness 
activities. ERPGs are the maximum airborne concentration below which it is believed that nearly all individuals could be exposed for up to 1 hour without experiencing mild (ERPG1), irreversible (ERPG2), or life-threatening health effects (ERPG3).

The National Academy of Sciences (NAS) developed emergency exposure guidance levels (EEGLs) for healthy young military personnel. An EEGL is a concentration of substance in air (as a gas, vapor, or aerosol) that the Department of Defense (DOD) judges acceptable for the performance of specific tasks during rare emergency conditions lasting for periods of 1 to 24 hours. Exposure at an EEGL might produce reversible effects that do not impair judgment and do not interfere with proper responses to the emergency. EEGLs are not applicable to general populations consisting of the elderly, the very young, pregnant women, and ill persons.

The Environmental Protection Agency (EPA) developed levels of concern (LOCs) for emergency planning. The Federal Emergency Management Agency (FEMA) and the U.S. Department of Transportation (USDOT) also use LOCs for emergency planning purposes. A LOC is the concentration of an extremely hazardous substance in air above which there may be serious irreversible health effects or death as a result of a single exposure for a relatively short period of time.

The guideline to follow (i.e., if a guideline has been established for a particular hazardous substance) is a decision to be made by each organization. These guidelines are not enforced by law. A description of each agency's (e.g., AIHA, NAS, and EPA) recommended emergency response exposure guideline is given in Appendix A.

The U.S. Army Center for Health Promotion and Preventive Medicine (USACHPPM) is currently working on developing airborne exposure guidance levels (AEGL) for chemical agents. However, it is unclear when these guidance levels will be completed and approved for use. For now, there are no emergency response exposure limits established for chemical warfare agents at this time (1999). This means that each organization would be responsible for determining and establishing its own emergency response guidelines. As a result, there would be a potential for inconsistency in guidelines from organization to organization and no assurance that the guidelines selected would be appropriate. An organization may choose not to establish its own emergency response guidelines however, this may cause the organization to change its original mission or purpose and subsequent work rules and PPE.

\section{Where Can I Go for More Information?}

More detailed information to aid in the selection of PPE can be obtained from sources such as those listed below. 
ACGIH (American Conference of Governmental Industrial Hygienists), 1996-1996 Threshold Limit Values (TLVs) for Chemical Substances and Physical Agents and Biological Exposure Indices (BEIs), Cincinnati: American Conference of Governmental Industrial Hygienists.

CFR, Title 29, Part 1910.120 Hazardous Waste Operations and Emergency Response (HAZWOPER) Standard.

CFR, Title 29, Subpart I - Personal Protective Equipment, 1910.132 through 1910.138.

Organization Resources Counselors (ORC). 1987. Memorandum to ORC Occupational Safety and Health Group from Darrell K. Mattheis and Rebecca L. Daiss, Update on Emergency Response Planning Guidelines (ERPG) Task Force. July 20, 1987.

U.S. Environmental Protection Agency, Federal Emergency Management Agency, and the U.S. Department of Transportation. Technical Guidance for Hazards Analysis, Emergency Planning for Extremely Hazardous Substances. December, 1987

Also included are World Wide Web homepage addresses for various regulatory and other accepted industry-wide organizations.

\begin{tabular}{ll}
\hline Agency & WWW Address \\
\hline & \\
Agency for Toxic Substances & \\
$\quad$ and Disease Registry & http://atsdrl.atsdr.cdc.gov:8080/atsdrhome.html \\
(ATSDR) & http://acgih.org/welcome.htm \\
ACGIH & http://www.aiha.org/ \\
AIHA & http://www.ansi.org/ \\
ANSI & \\
Centers for Disease Control & http://www.cdc.gov/ \\
and Prevention (CDC) & http://www.access.gpo.gov/nara/cfr-table-search.html \\
CFR & \\
U.S. Army's Edgewood Research & \\
Development and Engineering & http://www.cbdcom.apgea.army.mil/RDA/erdec/ \\
Center (ERDEC) & risk/safety/index.html \\
& \\
Environmental Protection & http://www.epa.gov/ \\
Agency (EPA) & http://www.fema.gov/ \\
FEMA & http://www.nfpa.org/ \\
NFPA & http://www.cdc.gov/niosh/homepage.html \\
NIOSH & http://www.osha.gov/ \\
OSHA &
\end{tabular}




\section{APPENDIX A}

\section{DEFINITIONS}

\section{Description of the American Conference of Governmental Industrial Hygienists (ACGIH) TLVs}

According to the ACGIH's Threshold Limit Values (TLVs) for Chemical Substances and Physical Agents and Biological Exposure Indices (BEIs), TLVs or threshold limit values refer to airborne concentrations of substances and represent conditions under which it is believed that nearly all workers may be repeatedly exposed day after day (i.e., a normal 8 hour workday and a 40 hour workweek, for 50 years) without adverse effect. Because of wide variation in individual susceptibility, however, a small percentage of workers may experience discomfort from some substances at concentrations at or below the threshold; a small percentage may be affected more seriously as a result of aggravation of a pre-existing condition or development of an occupational illness.

The ACGIH bases its threshold limits on the best available information from industrial experience, from experimental human and animal studies, and, when possible, from a combination of the three. The criteria on which the values are established may differ from substance to substance; protection against impairment of health may be a guiding factor in setting some values, whereas reasonable freedom from irritation, narcosis, nuisance or other forms of stress may form the basis for others.

The ACGIH has three categories of TLVs as defined in their Threshold Limit Values (TLVs) for Chemical Substances and Physical Agents and Biological Exposure Indices (BEIs). They are as follows:

- Threshold limit value-time weighted average (TLV-TWA) represents the time-weighted average concentration for a normal 8 hour workday and a 40 hour workweek, to which nearly all workers may be repeatedly exposed, day after day, without adverse effect.

How the ACGIH Computes Cumulative Exposure

The cumulative exposure for an 8 hour work shift can be computed as follows:

$$
E=(\mathrm{CaTa}+\mathrm{CbTb}+\mathrm{CnTn}) \div 8
$$


Where:

$E$ is the equivalent exposure for the working shift.

$\mathrm{C}$ is the concentration during any period of time $\mathrm{T}$ where the concentration remains constant.

$T$ is the duration in hours of the exposure at the concentration $C$.

8 is the work shift.

To illustrate the TLV-TWA concept, assume that substance A has an 8 hour TWA of 100 parts per million (ppm). Assume that an employee is subject to the following exposure: (1) two hours exposure at $150 \mathrm{ppm}$; (2) two hours exposure at $75 \mathrm{ppm}$; and (3) four hours exposure at $50 \mathrm{ppm}$.

$$
(2 \times 150+2 \times 75+4 \times 50) \div 8=81.25 \mathrm{ppm}
$$

Since $81.25 \mathrm{ppm}$ is less than $100 \mathrm{ppm}$, the 8 hour TWA limit, the exposure is acceptable.

- Threshold limit value-short term exposure limit (TLV-STEL) represents the concentration to which workers can be exposed continuously for a short period of time without suffering from (1) irritation, (2) chronic or irreversible tissue damage, or (3) narcosis (i.e., state of stupor or unconsciousness) of sufficient degree to increase the likelihood of accidental injury, impair self-rescue or materially reduce work efficiency. A STEL is defined as a 15 minute TWA exposure which should not be exceeded at any time during a work day even if the 8 hour TWA is within the TLV. Single exposures at the STEL should not be longer than 15 minutes and should not be repeated more than four times per day. STELs are recommended (instead of TLV-TWA or TLV-C) for substances where toxic effects have been reported from high short term exposures in either humans or animals.

- Threshold limit value-ceiling (TLV-C) represents the concentration that should not be exceeded during any part of the working exposure.

Exposures to carcinogens must be kept to a minimum. Current scientific debate over the existence of biological thresholds for carcinogens is likely to continue for some time. The ACGIH has established values for some substances determined to be carcinogenic. In order to provide practical guidelines to control exposures in the workplace, there are five categories of carcinogens - A1 Confirmed Human Carcinogens; A2 Suspected Human Carcinogens; A3 Animal Carcinogens; A4 Not Classifiable as a Human Carcinogen, and; A5 Not Suspected as a Human Carcinogen. 


\section{Description of the NIOSH Recommended Exposure Limits (RELS)}

According to the NIOSH Pocket Guide to Chemical Hazards, NIOSH develops RELs for hazardous substances or conditions (e.g., physical agents such as heat, noise, vibration, etc.) in the workplace. RELs are a time-weighted average concentration for up to a 10-hour workday during a 40-hour workweek for 50 years. To formulate these recommendations, NIOSH evaluates all known and available medical, biological, engineering, chemical, trade, and other information relevant to the hazards. These recommendations are then published and transmitted to OSHA. RELs are prepared to assist OSHA in the formulation of legal standards. NIOSH has three categories of RELs.

$\begin{array}{ll}\text { - } & \text { REL-TWA } \\ \text { - } & \text { REL-STEL } \\ & \text { REL-C }\end{array}$

\section{Description of the OSHA Permissible Exposure Limits (PELs)}

OSHA has PELs as defined in 29 Code of Federal Regulations (CFR), 1910.1000, Air . Contaminants. PELs are a time-weighted average concentration that must not be exceeded during any 8 hour work shift of a 40 hour workweek for 50 years. OSHA has three categories of PELs.

$\begin{array}{ll}- & \text { PEL-TWA } \\ - & \text { PEL-STEL } \\ \text { - } & \text { PEL-C }\end{array}$

Most OSHA PELs were promulgated initially from the 1968 ACGIH list of TLVs. The ACGIH TLVs are updated each year and reflect the most current information regarding exposure levels, health effects, and changes in technology that allow equipment to detect hazardous substances at a smaller concentration. Because the ACGIH TLVs have been updated annually, the ACGIH TLVs may be more stringent than OSHA PELs. Although the PELs represent the legal maximum levels of contaminants, it would be prudent to follow the ACGIH TLVs to best protect the health of workers.

In summary, there are several nationally recognized agencies that have established exposure levels for workers. Traditionally, agencies such as the ACGIH update their exposure levels more frequently than OSHA. As a result, their exposure levels may best protect the health of workers. However, OSHA's PELs are the only standards enforced by law. 
Table 2.2 Agency Exposure Limits

\begin{tabular}{|c|c|c|c|}
\hline Agency & $\begin{array}{l}\text { Enforced } \\
\text { by Law }\end{array}$ & Category & Definition \\
\hline ACGIH & No & $\begin{array}{l}\text { Threshold Limit Value-Time } \\
\text { Weighted Average TLV-TWA }\end{array}$ & $\begin{array}{l}\text { Average concentration for } 8 \mathrm{hr} \\
\text { day } / 40 \mathrm{hr} \text { week to which workers } \\
\text { may be exposed day after day } \\
\text { without adverse effect. }\end{array}$ \\
\hline ACGIH & No & $\begin{array}{l}\text { Short Term Exposure Limit } \\
\text { (STEL) } \\
\text { TLV-STEL }\end{array}$ & $\begin{array}{l}\text { Concentration to which workers can } \\
\text { be exposed continuously for } 15 \\
\text { minutes without suffering from } \\
\text { irritation or irreversible damage, or } \\
\text { impairing self-rescue. }\end{array}$ \\
\hline ACGIH & No & $\begin{array}{l}\text { Ceiling Limit (C) } \\
\text { TLV-C }\end{array}$ & $\begin{array}{l}\text { Maximum concentration that } \\
\text { workers may be exposed at any and } \\
\text { all times. }\end{array}$ \\
\hline OSHA & Yes & $\begin{array}{l}\text { Permissible Exposure Limit } \\
\text { PEL-TWA }\end{array}$ & $\begin{array}{l}\text { Average concentration for } 8 \mathrm{hr} \\
\text { day } / 40 \mathrm{hr} \text { week to which workers } \\
\text { may be exposed day after day } \\
\text { without adverse effect. }\end{array}$ \\
\hline OSHA & Yes & PEL-STEL & $\begin{array}{l}\text { Concentration to which workers can } \\
\text { be exposed continuously for } 15 \\
\text { minutes without suffering from } \\
\text { irritation or irreversible damage, or } \\
\text { impairing self-rescue. }\end{array}$ \\
\hline OSHA & Yes & PEL-C & $\begin{array}{l}\text { Maximum concentration that } \\
\text { workers may be exposed at any and } \\
\text { all times. }\end{array}$ \\
\hline $\mathrm{NIOSH}$ & No & $\begin{array}{l}\text { Recommended Exposure Limit } \\
\text { REL-TWA }\end{array}$ & $\begin{array}{l}\text { Average concentration for } 10 \mathrm{hr} \\
\text { day } / 40 \mathrm{hr} \text { week to which workers } \\
\text { may be exposed day after day } \\
\text { without adverse effect. }\end{array}$ \\
\hline $\mathrm{NIOSH}$ & No & REL-STEL & $\begin{array}{l}\text { Concentration to which workers can } \\
\text { be exposed continuously for } 15 \\
\text { minutes without suffering from } \\
\text { irritation or irreversible damage, or } \\
\text { impairing self-rescue. }\end{array}$ \\
\hline $\mathrm{NIOSH}$ & No & REL-C & $\begin{array}{l}\text { Maximum concentration that } \\
\text { workers may be exposed at any and } \\
\text { all times. }\end{array}$ \\
\hline
\end{tabular}


In the absence of chemical agent worker exposure limits by OSHA, NIOSH, or the ACGIH, the Centers for Disease Control and Prevention (CDC) published general population and agent worker airborne exposure limits in the Federal Register, Tuesday, March'15, 1988, Vol. 53, No. 50. In 1992, the U.S. Army Surgeon General established IDLH limits for military use in the absence of NIOSH-established IDLH limits. These IDLH limits were based on recommendations from the U.S. Army Environmental Hygiene Agency and are to be used for the purpose of establishing the concentrations at which SCBAs or supplied air respirators are required by military personnel. The CDC's general population and agent worker exposure limits and the Army's IDLH exposure limits are shown below.

Table 2.3. CDC General population, worker exposure limits, and Army IDLH limits $\mathrm{CDC}$ $\mathrm{CDC}$ General Population Airborne Exposure Agent Worker U. S. Army

\begin{tabular}{llll} 
Agent & $\begin{array}{c}\text { General Population } \\
\text { Airborne Exposure } \\
\text { Limits }\end{array}$ & $\begin{array}{c}\text { Agent Worker } \\
\text { Airborne Exposure } \\
\text { Limits }\end{array}$ & \multicolumn{1}{c}{$\begin{array}{c}\text { U. S. Army } \\
\text { IDLH Airborne } \\
\text { Exposure Limits }\end{array}$} \\
\hline GA, GB & $0.0000003 \mathrm{mg} / \mathrm{m}^{3}$ & $0.0001 \mathrm{mg} / \mathrm{m}^{3}$ & $0.2 \mathrm{mg} / \mathrm{m}^{3}$ \\
$\mathrm{VX}$ & $0.000003 \mathrm{mg} / \mathrm{m}^{3}$ & $0.0001 \mathrm{mg} / \mathrm{m}^{3}$ & $0.02 \mathrm{mg} / \mathrm{m}^{3}$ \\
$\mathrm{H}, \mathrm{HD}, \mathrm{HT}$ & $0.0001 \mathrm{mg} / \mathrm{m}^{3}$ & $0.003 \mathrm{mg} / \mathrm{m}^{3}$ & $0.003 \mathrm{mg} / \mathrm{m}^{3 *}$ \\
L & & & \\
$\begin{array}{l}\text { Averaging } \\
\text { Time }\end{array}$ & $0.003 \mathrm{mg} / \mathrm{m}^{3}$ & $0.003 \mathrm{mg} / \mathrm{m}^{3}$ & $0.003 \mathrm{mg} / \mathrm{m}^{3}$ \\
\hline
\end{tabular}

Recommended Emergency Response Exposure Guidelines

Traditional TLV-TWA exposure limits do not fit the work to be performed when that work involves emergency response efforts. Emergency response workers (e.g., CSEPP participants) need exposure limits for exposure at high levels of short duration, that occurs only once in a lifetime.

There are no exposure limits established by OSHA for emergency response efforts. In recognition of this need, emergency response exposure guidelines have been developed by several nationally recognized agencies for some extremely hazardous substances. An organization should be familiar with the different exposure guidelines established, and choose the guideline appropriate for the work to be performed, the hazardous substance(s) 
involved, and the group potentially exposed (e.g., emergency response workers, general public, etc). A brief description of each agency's recommended emergency response exposure guideline is given below. These guidelines are not enforced by law.

Description of the American Industrial Hygiene Association's (AIHA) Emergency Response Planning Guidelines (ERPGs)

The AIHA developed the following ERPGs for community emergency response purposes. The Department of Energy (DOE) uses the AIHA ERPGs as the primary chemical exposure criteria for DOE emergency planning and preparedness activities. The AIHA defined ERPGs as follows:

- ERPG-1: The maximum airborne concentration below which it is believed that nearly all individuals could be exposed for up to 1 hour (without a respirator) without experiencing other than mild transient adverse health effects or without perceiving a clearly defined objectionable odor.

- ERPG-2: The maximum airborne concentration below which it is believed that nearly all individuals could be exposed for up to 1 hour without experiencing or developing irreversible or other serious health effects or symptoms that could impair their abilities to take protective action.

- ERPG-3: The maximum airborne concentration below which it is believed nearly all individuals could be exposed for up to 1 hour without experiencing or developing life-threatening health effects.

\section{Description of the National Academy of Sciences (NAS) Emergency Exposure Levels}

The NAS has developed the following guidelines for healthy young military personnel to use in their own emergency response operations. These guidelines are used in planning for sudden contamination of air during military and space operations; specifically, they are used as an aid in choosing protective equipment and response plans after non-routine but predictable occurrences such as line breaks, spills, and fires. These guidelines are for peak levels of exposure considered acceptable for rare situations, but are not to be applied in instances of repeated exposure.

- Emergency Exposure Guidance Level (EEGL): A concentration of a substance in air (as a gas, vapor, or aerosol) that the Department of Defense (DOD) judges acceptable during performance of specific tasks under rare emergency conditions lasting for periods of 1 to 24 hours. Exposure at an EEGL might produce reversible effects that do not impair judgment and do not interfere with proper responses to the emergency. The EEGL is a ceiling guidance level for each emergency exposure, usually lasting from 1 hour to 24 hours, which is expected to be infrequently encountered in a person's lifetime. 
- $\quad$ Continuous Exposure Guidance Level (CEGL): CEGLs are ceiling concentrations designed to prevent immediate and delayed health effects attributable to more prolonged exposures, and to prevent degradation in crew performance that might endanger the objectives of a particular mission due to continuous exposure for up to 90 days.

- Short Term Public Emergency Guidance Level (SPEGL): SPEGL is defined as a suitable concentration for unpredicted single, short term, emergency exposure of the general public. The exposure period is usually calculated to be one hour or less and never more than 24 hours. In contrast to the EEGL, the SPEGL takes into account the wide range of susceptibility of the general public. This includes sensitive populations - such as children, the aged, and persons with serious debilitating diseases.

Description of the Environmental Protection Agency's (EPA) Emergency Planning Guideline

The EPA developed levels of concern (LOCs) for emergency planning. FEMA and the USDOT also use LOCs for emergency planning purposes.

- The LOC is the concentration of an extremely hazardous substance in air above which there may be serious irreversible health effects or death as a result of a single exposure for a relatively short period of time.

The U.S. Army Center for Health Promotion and Preventive Medicine (USACHPPM) is currently working on developing airborne exposure guidance levels (AEGL) for chemical agents. However, it is unclear when these guidance levels will be completed and approved for use. For now, there are no emergency response exposure limits established for chemical warfare agents at this time (1999). This means that each organization would be responsible for determining and establishing its own emergency response guidelines. As a result, there would be a potential for inconsistency in guidelines from organization to organization and no assurance that the guidelines selected would be appropriate. An organization may choose not to establish its own emergency response guidelines however, this may cause the organization to change its original mission or purpose and subsequent work rules and PPE. 


\section{INFORMATION SHEET TO AID IN THE UNDERSTANDING OF MEDICAL REQUIREMENTS FOR WORKERS WEARING RESPIRATORY EQUIPMENT}

\section{Who is the Intended Audience?}

The intended audience for this information sheet are those individuals responsible for an organization's respiratory protection program, individuals who may participate in the selection of personal protective equipment (PPE), or for the worker who wants to increase his/her basic knowledge and understanding of medical requirements for workers wearing respiratory equipment As this information sheet is intended as an overview of a complex subject, users are encouraged to consult the references cited herein for additional assistance.

\section{Which Occupational Safety and Health Administration (OSHA) Standard Should Be Used?}

The standard developed for respiratory protection is 29 Code of Federal Regulations (CFR) 1910.134 Respiratory Protection, which includes medical requirements. In addition, some regulatory standards for specific substances (e.g., 1910.1001 for asbestos, 1910.1025 for lead, etc.) and occupations may also contain requirements for medical examinations. For example, medical requirements can be found in OSHA standard 29 CFR 1910.120 Hazardous Waste Operations and Emergency Response (HAZWOPER). The type of work to be performed and/or the contaminant to be encountered will determine the appropriate standard.

This information sheet will focus on two specific OSHA standards:

- $\quad 29$ CFR 1910.134 Respiratory Protection, and

- 29 CFR 1910.120 HAZWOPER.

Only federal regulations are discussed in this information sheet. Each State must, at a minimum, meet federal regulatory requirements. However, for those States with federally-approved State OSHA plans, State requirements can be more stringent than federal requirements. Check for such State and local requirements where applicable. 


\section{Who Needs Medical Surveillance?}

According to 29 CFR 1910.134, employers must provide respirators to their employees when such equipment is needed to protect the health of the employee. The employer is then responsible for the establishment and maintenance of a respiratory program which includes medical surveillance.

The HAZWOPER standard (i.e., 29 CFR 1910.120), was written to ensure adequate protection for workers at Superfund sites; Resource Conservation and Recovery Act (RCRA) regulated sites; recognized voluntary clean-up sites; and regulated treatment, storage and disposal (TSD) facilities. This standard addresses three distinctive scopes of activities; hazardous waste site clean-up, TSD facilities, and emergency response operations at the site of the release. According to HAZWOPER, medical surveillance is required for the following employees.

- Employees who are, or may be exposed to hazardous substances or health hazards at, or above the permissible exposure limits without regard to the use of the respirator for 30 days or more a year.

- Employees who wear a respirator for 30 days or more a year.

- Employees who are injured, become ill or develop signs or symptoms due to possible overexposure involving hazardous substances or health hazards from an emergency response or hazardous waste operations.

- Members of designated hazardous materials (HAZMAT) teams.

\section{What Are the Medical Evaluation Requirements From 29 CFR 1910.134?}

According to 1910.134 (e) (1):

The employer shall provide a medical evaluation to determine the employee's ability to use a respirator, before the employee is fit tested or required to use the respirator in the workplace.

\section{Content of Medical Evaluation}

Workers are required to have a medical evaluation to determine if they are able to use the respiratory equipment. The employer shall identify a physician or other licensed health care professional to perform medical evaluations using a medical questionnaire or an initial medical examination that obtains the same information outlined in 1910.134 Appendix C, OSHA Respirator Medical Evaluation Questionnaire (Mandatory). A copy of Appendix C is attached as Appendix A, OSHA Respirator Medical Evaluation Questionnaire. 
The employer shall provide additional medical evaluations under the following conditions.

- An employee reports medical signs or symptoms that are related to ability to use a respirator;

- A physician or other licensed health care professional, supervisor, or the respirator program administrator informs the employer that an employee needs to be reevaluated;

- Information from the respiratory protection program, including observations made during fit testing and program evaluation, indicates a need for employee reevaluation; or

- A change occurs in workplace conditions (e.g., physical work effort, protective clothing, temperature) that may result in a substantial increase in the physiological burden placed on an employee.

\section{Evaluations and Costs}

All medical evaluations (i.e., questionnaires, physical examinations, and follow-up physical examinations) shall be administered confidentially during the employee's normal working hours or at a time and place convenient to the employee. The employer shall provide respirators, training, and medical evaluations at no cost to the employee.

\section{Information Provided to the Physician or Licensed Health Care Professional}

The employer shall provide a copy of 1910.134 (e) (5) (i) and a copy of their written respiratory protection program to the attending physician or licensed health care professional. In addition, the following information must also be provided before a recommendation concerning an employee's ability to use a respirator can be completed.

- The type and weight of the respirator to be used by the employee;

- The duration and frequency of respirator use (including use for rescue and escape);

- The expected physical work effort;

- $\quad$ Additional protective clothing and equipment to be worn; and

- Temperature and humidity extremes that may be encountered. 


\section{Physician's Written Opinion}

The employer shall obtain a written recommendation regarding the employee's ability to use the respirator from the physician or licensed health care professional. The written recommendation should provide only the following information.

- Any limitations on respirator use related to the medical condition of the employee, or relating to the workplace conditions in which the respirator will be used, including whether or not the employee is medically able to use the respirator;

- The need, if any, for follow-up medical evaluations; and

- A statement that the physician or licensed health care professional has provided the employee with a copy of the written recommendation.

NOTE: If the respirator is a negative pressure respirator and the physician or licensed health care professional finds a medical condition that may place the employee's health at increased risk if the respirator is used, the employer shall provide a powered air-purifying respirator (PAPR) if the physician or licensed health care professional's medical evaluation finds that the employee can use such a respirator; if a subsequent medical evaluation finds that the employee is medically able to use a negative pressure respirator, then the employer is no longer required to provide a PAPR.

\section{Recordkeeping}

The employer is required to establish and retain written information regarding medical evaluations, fit testing, and the respirator program.

\section{What Are the Medical Requirements From 29 CFR 1910.120?}

\section{Content of Medical Examinations}

The medical examination shall include a medical and work history with special emphasis on the following factors that may be present at the work site. These factors include:

- symptoms related to the handling of hazardous substances and health hazards,

- $\quad$ fitness for duty including the ability to wear any required PPE under adverse conditions (i.e., temperature extremes).

The actual content of the medical examination or consultation shall be determined by the attending physician. The guidelines in Chapter 5, Medical Program from the Occupational Safety and Health Guidance Manual for Hazardous Waste Site Activities should be consulted and is attached as Appendix B, OSHA Medical Program Guidelines. 


\section{Frequency of Medical Examinations}

The HAZWOPER standard requires workers (i.e., workers at Superfund sites; RCRA regulated sites; recognized voluntary clean-up sites; and regulated TSD facilities) to have a medical examination under the following conditions:

- Prior to job assignment and at least once every 12 months for each employee unless the attending physician believes a longer interval is appropriate (not greater than biennially).

- Upon termination of employment or reassignment to an area where the employee would not be covered (if the employee has not had an examination within the last six months).

- If the examining physician determines that an increased frequency of examination is medically necessary, medical examinations may be required at more frequent times.

- Upon notification by an employee that the employee has developed signs or symptoms indicating possible overexposure to hazardous substances or health hazards.

- If the employee has been injured or exposed above the permissible exposure limits (PELs), or published exposure levels in an emergency situation.

For the HAZMAT team members involved in emergency response operations at the site of the release, a medical examination is required under the following conditions:

- If injured, received a health impairment, developed signs or symptoms which may have resulted from exposure to hazardous substances resulting from an emergency incident.

- If exposed during an emergency incident to hazardous substances at concentrations above the PELs, or published exposure levels without the necessary personal protective equipment (PPE).

- As soon as possible following the emergency incident or development of signs and symptoms.

- At additional times, if examining physician determines that follow-up examinations or consultations are medically necessary.

\section{Examination by a Physician and Costs}

All medical examinations and procedures shall be performed by or under the supervision of a licensed physician, preferably one knowledgeable in occupational medicine, and shall be provided without cost to the employee, without loss of pay, and at a reasonable time and place. 


\section{Information Provided to the Physician and Employee}

The employer shall provide one copy of the HAZWOPER standard and its appendices to the attending physician, and in addition the following for each employee:

- A description of the employee's duties as they relate to the employee's exposures.

- The employee's exposure levels or anticipated exposure levels.

- A description of any PPE used or to be used.

- Information from previous medical examinations of the employee which is not readily available to the examining physician.

\section{Physician's Written Opinion}

The employer shall obtain and furnish the employee with a copy of the written opinion from the attending physician containing the physician's opinion as to:

- Whether the employee has any detected medical conditions which would place the employee at increased risk of material impairment of the employee's health from work in hazardous waste operations or emergency response, or from respirator use.

- The physician's recommended limitations upon the employee's assigned work.

- The results of the medical examination and tests if requested by the employee.

- A statement that the employee has been informed by the physician of the results of the medical examination and any medical conditions which require further examination or treatment.

- The written opinion obtained by the employer shall not reveal specific findings or diagnoses unrelated to occupational exposures.

\section{Recordkeeping}

An accurate record of the medical surveillance shall be retained. This record shall be retained for the period specified and meet the criteria of 29 CFR 1910.1020 (30 years). The record shall include at least the following information:

- Name and social security number of the employee.

- Physician's written opinions, recommended limitations, and results of examinations and tests.

- Any employee medical complaints related to exposure to hazardous substances.

- A copy of the information provided to the examining physician by the employer, with the exception of the HAZWOPER standard and its appendices. 


\section{Where Can I Go for More Information?}

More detailed information can be obtained from sources such as those listed below.

ACGIH (American Conference of Governmental Industrial Hygienists), 1996-1996

Threshold Limit Values (TLVS) for Chemical Substances and Physical Agents and Biological Exposure Indices (BEIs), Cincinnati: American Conference of Governmental Industrial Hygienists.

ANSI (American National Standards Institute), American National Standard for Respiratory Protection, ANSI Z88.2-1992, New York.

CFR, Title 29, Part 1910.120 Hazardous Waste Operations and Emergency Response (HAZWOPER) Standard.

CFR, Title 29, HAZWOPER Standard, Appendix A - Personal Protective Equipment Test Methods.

CFR, Title 29, HAZWOPER Standard, Appendix B - General Description and Discussion of the Levels of Protection and Protective Gear.

CFR, Title 29, HAZWOPER Standard, Appendix C - Compliance Guidelines.

CFR, Title 29, Subpart I - Personal Protective Equipment, 1910.132 through 1910.138.

OSHA (Occupational Safety and Health Administration), Hospitals and Community Emergency Response - What You Need to Know, Department of Labor, OSHA 3152, Washington, DC, 1997.

Also included are World Wide Web homepage addresses for various regulatory and other accepted industry wide organizations.

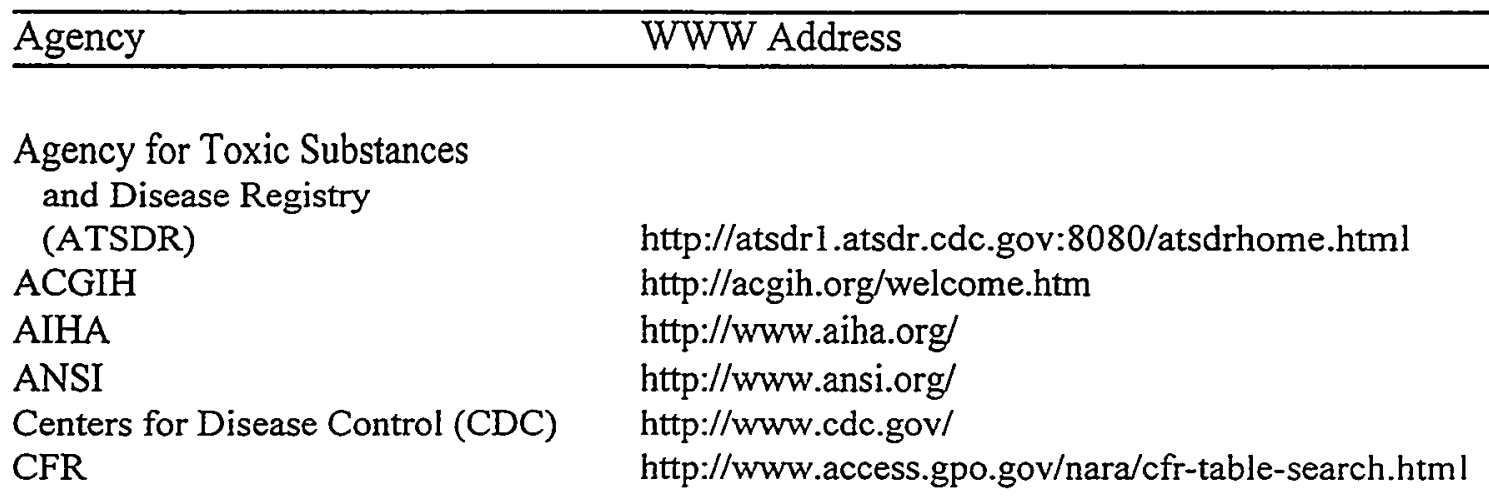


Environmental Protection

$\begin{array}{ll}\text { Agency (EPA) } & \text { http://www.epa.gov/ } \\ \text { FEMA } & \text { http://www.fema.gov/ } \\ \text { NFPA } & \text { http://www.nfpa.org/ } \\ \text { NIOSH } & \text { http://www.cdc.gov/niosh/homepage.html } \\ \text { OSHA } & \text { http://www.osha.gov/ }\end{array}$


APPENDIX A

OSHA RESPIRATOR MEDICAL

EVALUATION QUESTIONNAIRE

(MANDATORY) 


\section{Appendix A}

\section{OSHA Respirator Medical Evaluation Questionnaire}

\section{(Mandatory)}

\section{Appendix C to 29 CFR 1910.B4}

*To the employer. Answers to questions in Section 1, and to question 9 in Section 2 of Part A, do not require a medical examination.

*To the employee:

* Can you read (circle one): YesiNo

- Your employer must allow you to answer this questionnaire during normal working hours, or at a time and place that is convenient to you. To maintain your confidentiality, your employer or supervisor must not look at or review your answers, and your employer must tell you how to deliver or send this questionnaire to the health care professional who will review it.

-Part A. Section I. (Mandatory) The following information must be provided by every employee who has been selected to use any type of respirator (please print).

*1. Today's date:

*2. Your name

*3. Your age (to nearest year):

*4. Sex (circle one): Maleffemale

*5. Your height: ft. in.

*6. Your weight Ibs.

7. Your job title:

*8. A phone number where you can be reached by the health care professional who reviews this questionosire (include the Area Code):

4. The best time to phone you at this number.

* 10. Has your employer told you how to contact the health care professional who will review this questionaire (circle one): YesNo

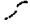

*11. Check the type of respirator you will use (you can check more than one category)

* a. N, R or P disposable respirator (filter-mask, non- cartidge type only).
*b. Other type (for example, half- or full-facepiece type, powered-air purifying, supplied-air, self-contained breathing apparatus).

*12. Have you worn a respirator (circle one): YesNo 
- If "yes," what type(s):

*Part A. Section 2. (Mandatory) Questions 1 through 9 below must be answered by every employee who has been selected to use any type of respirator (please circle "yes" or "no").

1. Do you currently smoke tobacco, or have you snoked tobacco in the last month: Yes/No

2. Have you ever had any of the following conditions?

*a. Seizures (fits): Yes No

*b. Diabetes (sugar disease): Yes/No

*c. Allergic reactions that interfere with your breathing: YesNo

*d. Claustrophobia (fear of closed-in places): Yes/No

*. Trouble smelling odors: Yes/No

-3. Have you ever had any of the following pulmonary or lung problems?

*a. Asbestosis: Yes No

*b. Asthme: Yesino

*. Chronic bropchitis: Yes/No

*d Emphysema: YesiNo

*e. Preumonia: Yes/No

*f Tuberculosis: YesNo

* g. Silicosis: Yes No

*h. Pneumothorax (collapsed lung): Yes/No

*i. Inng cancer. Yes/No

*. Brokea ribs: YesNo

*k Any chest injuries or surgeries: YesNo

*L. Any other lung problem that you've been told about YesNo

-4. Do you currently have any of the following symptoms of pulmonary or lung illness?

*a. Shortness of bresth: YesNo

*b. Shortness of breath when walking fast on level ground or walling up a slight hill or incline: Yes/No

*c. Shortness of breath when walking with other people at an ordinary pace on level ground: Yes No

d. Have to stop for breath when walking at your own pace on level ground: YesNo

*e. Shorteess of breath when washing or dressing yourself Yes/No

-f. Shortness of breath that interferes with your job: Yes/No

* Coughing that produces phlegen (thick sputum): Yes/No

7h. Coughing that wakes you early in the morning. Yes No

*i. Coughing that oceurs mostly when you are lying dom: Yes No

*. Coughing up blood in the last month: YesNo

*k theezing. Yes No

-1. Wheezing that intefferes with your job: YesNo

*m. Chest pain when you bresthe deeply: Yes No

*n Any other symoptoms that you think may be related to lang problems: YesNo

-5. Have you ever had any of the following cardiovasalar or heart problems?

*a. Heart attack YesNo

*b. Stroke: Yes/No

"c. Angina: Yes/No

*d. Heart failure: YesNo

*c. Swelling in your legs or feet (not caused by walking): Yes/No

*f. Heart arthythmia (heart beating irregularly): Yes/No

- g. High blood pressure: YesiNo

*h. Any other heart problem that you've been told about: YesNo

*6. Have you ever had any of the following cardiovascular or heart symptoms?

*a. Frequent pain or tightness in your chest: Yes/No

*b. Pain or tightmess in your chest during physical activity: Yes/No

*c. Pain or tightness in your chest that interferes with your job: Yes/No

*d In the past two years, have you noticed your heart skipping or missing a bear. Yes No 


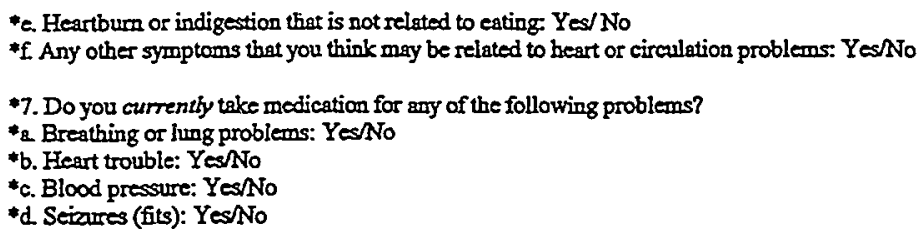

-8. If you've used a respirator, have you ever had any of the following problens? (If you've never used a respirator, check the folloping space and go to question 9:)

* a Eye irritation: Yes No

*b. Skin allergies or rashes: Yes/No

*. Anxiety: YesNo

*d. General wealness or fatigue: YesiNo

* Any otber problem that interferes with your use of a respirator: Yes/No

-9. Would you like to talk to the health care professional who will review this questionaire about your answers to this questionnaire: Yes/No

*Questions 10 to 15 below must be answered by every employee who has been selected to use either a full-facepiece respirator or a self-contained breathing apparatus (SCBA). For employees who have been selected to use other types of respirators, answering these questions is voluntary.

*10. Have you ever last vision in either eye (temporarily or permanently): Yes/No

*11. Do you currently have any of the following vision problems?

* Wear contect lenses: YesNo

* b. Wear glasses: Yes No

*c. Color blind: YesNo

*e. Any other eye or vision problem: YesNo

12. Five you ever had an injury w your ears, inciuding a broken ear dirum: YesiNo

*13. Do you currently have any of the following hearing problems?

* a. Difficulty hearing: Yes No

b. Wear a hearing aid: Yes/No

* c. Any other hearing or ear problem: Yes/No

*14. Have you ever had a back injury: YesNo

*1S. Do you currently have any of the following musculoskeletal problems?

*a. Wealness in any of your arms, hands, legs, or fet: Yes $n$ No

*b. Back pain: Yes No

*c. Difficulty fully moving your arms and legs: Yes/No

* Pain or stiffess when you lean forward or backward at the waist YesNo

*e. Difficulty fully moving your head up or down: YesiNo

* Difficulty fully moving your head side to side: YesNo

* $g$. Difficulty bending at your knees: YesiNo

*h. Difficulty squatting to the gromd: YeaNo

* i. Climbing a flight of stairs or a ladder carrying more than $25 \mathrm{lbs}$. Yes/No

*j. Any other muscle or skeletal problem that interferes with using a respirator: Yes No

*Part B Any of the following questions, and other questions not listed, may be added to the questionnaire at the discretion of the health care professional who will review the questiomaire.

*1. In your present job, are you working at high altitudes (over 5,000 feet) or in a place that has lower than nommal amounts of oxygen: Yes No

If "yes," do you have feelings of diziness, shortness of breath, pounding in your chest, or other symptoms when you're wotking under these conditions: Yes/No 
72. At work or at home, have you ever been exposed to hazardous solvents, hazardous airbome chemicals (e.g. gases, furnes, or dust), or have you come into skin contact with hazardous chemicals: YesNo

If "yes," name the chemicals if you boow them:

*3. Have you ever worked with any of the materials, or under any of the conditions, listed below:

a. Asbestos: YesNo

b. Silica (e.g., in sandblasting): YesNo

c. Tungsten /cobsit (c.g., ginding or welding this material): Yes/No

d. Beyllium: YesNo

c. Aluminum: YesiNo

f. Coal (for example, mining): YesNo

g Iron: YesNo

h. Tin: YesNo

i. Dusty environments: Yes/No

j. Any other hazardous exposures: Yes/No

If "yes," describe these exposures:

$\longrightarrow$

*4. List any second jobs or side businesses you have.

*5. List your previous occupations:

*6. List your,current and previous hobbies:

7. Have you been in the military services? YesNo

If "yes," were you exposed to biological or chemical ageats (either in training or combat): YesNo

*8. Have you ever worked on a HAZMAT team? YesANo

*9. Other than medications for breathing and lung problems, heart trouble, blood pressure, and seizures meationed earlier in this questionnaire, are you taking any other medications for any reason (including over-the-comter medications): YesNo"

If "yes," name the medications if you know them:

*10. Will you be using any of the following itens with your respirator(s)?

a. HEPA Filters: Yes No

b. Canisters (for example, gas masks): YesNo

c. Cartridges: YesiNo

"11. How often are you expected to use the respirator(s) (circle "yes" or "no" for all answers that apply to you)?:

a. Escape only (no reseue): YesNo

b. Emergency reseue only: Yes/No

c. Less than 5 hours per week YesNo

d Less than 2 hours per day: YesNo

e. 2 to 4 hours per day: YesiNo

$f$ Over 4 hours per day. YesiNo

12. During the period you are using the respirator(s), is your work effort

a. Light (less than 200 keal per hour): Yes/No

If "yes," how long does this period last during the average shift brs. $\operatorname{mins}$

Examples of a light work effort are sitting while writing, typing, drafting, or performing light assembly work, or standing while operating a drill press ( $1-3 \mathrm{lbs}$.) or controlling machines.

b. Moderate (200 to $350 \mathrm{keal}$ per hour): YesNo 
OSHEA R-gulations (Standerds - 29 CFR) - 1910.134 App C - Respiratory Protoction.

http:/www.0shs-slc.gov/OsbStd_data/1910_0134_APP_C.html

hrs. mins.

If "yes," how long does this period last during the average shift: mins. Examples of moderate work effort are sitting while nsiling or filing, driving s truck or bus in urban traffic; standing while drilling nailing, performing assembly work, or transferring a moderate losd (about $35 \mathrm{Ibs}$.) at trunk level; walling on a level surface about $2 \mathrm{mph}$ or down a 5 -degree grade about $3 \mathrm{mph}$; or pushing a wheelbarrow with a heavy load (about $100 \mathrm{lbs}$.) on a level surface.

c. Heovy (above 350 keal per hour): Yes No

If "yes," how long does this period last during the average shift: hrs. mins. Examples of heavy work are lifting a heavy load (about $50 \mathrm{lbs}$.) from the floor to your waist or shoulder, working on a loading dock, shoveling; standing while bricklaying or chipping castings, walking up an 8-degree grade abour 2 mph; climbing stairs with a heavy losd (about 50 lbs.).

*13. Will you be wearing protective clothing and/or equipmeat (other than the respirator) when you're using your respirator. YesiNo

If "yes," deseribe this protective clothing and/or equipment

*14. Will you be working under hot conditions (temperature exceeding $77 \mathrm{deg}$. F): Yes/No

*15. Will you be working under humid conditions. Yes Nọ

16. Describe the work you'll be doing while you're using your respirator(s):

*17. Describe any special or hazardous conditions you might encounter when you're using your respirator(s) (for example, confined spaces, life-threatening gases):

*18. Provide the following information, if you know it, for each toxic substance that you'll be exposed to when you're using your respirator(s):

Name of the first toxic substance:

Estimated maximin exposure level per shift:

Duration of exposure per shift

Name of the second toxic substance.

Estimated maximum exposure level per shift:

Duration of exposure per shift:

Name of the third toxic substance:

Estimated maximum exposure level per shift

Duration of exposure per shift:

The name of any other toxic substances that you'li be exposed to while using your respirator.

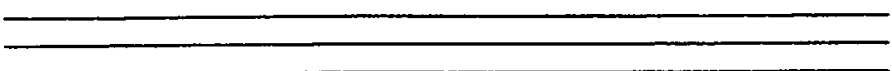

119. Describe any special responsibilities you'll have while using your respirator(s) that may affect the safety and well-being of others (for example, rescue, security):

* [63 FR 1152, Jan 8, 1998] 
APPENDIX B

Occupational Safety and Health Guidance Manual for Hazardous Waste Site Activities

Chapter 5 Medical Program 


\section{Appendix B}

\section{Occupational Safety and Health Guidance Manual for Hazardous Waste Site Activities}

Chapter 5 Medical Program

\section{Introduction}

Workers handling hazardous wastes can experience high levels of stress. Their daily tasks may expose them to toxic chemicals, safety hazards, biologic hazards, and radiation. They may develop heat stress while wearing protective equipment or working under temperature extremes, or face life-threatening emergencies such as explosions and fires. Therefore, a medical program is essential to assess and monitor workers' health and fitness both prior to employment and during the course of work; to provide emergency and other treatment as needed; and to keep accurate records for future reference. In addition, OSHA recommends a medical evaluation for employees requirad to wear a respirator 129 CFR Part 1910.134[b][10]), and certain OSHA standards include specific medical requirements (e.g., 29 CFR Part 1910.95 and 29 CFR Parts 1910.1001 through 1910.1045). Information from a site medical program may also be used to conduct future epidemiological studies; to adjudicate claims; to provide evidence in litigation; and to report workers' medical conditions to federal, state, and local agencies, as required by law.

This chapter presents genaral guidelines for designing a medical program for personnel at hazardous waste sites. It includes information and sample protocols for preemployment screening and periodic medical examinations, guidelines for emergency and non-emergency treatment, and recommendations for program recordkeeping and review. In addition, it supplies a table of some common chemical toxicants found at hazardous waste sites with recommended medical monitoring procedures.

The recommendations in this chapter assume that workers will have adequate protection from exposures through administrative and engineering controls, and appropriate personal protective equipment and decontamination procedures, as described elsewhere in this manual. Medical surveillance should be used to complement other contrals.

\section{Devoloping a Program}

A medical program should be developed for each site based on the specific needs, location, and potential exposures of employoes at the site. The program should be designed by an experienced occupational health pirysician or other qualified occupational health consultant in conjunction with the Site Safety Officer. The director of a site medical program should be a physician who is boardcertified in occupational medicine or a medical doctor who has had extensive experience managing occupational health services. A director and/or examining physician with such qualifications may be difficuit to find, due to the shortage of doctors trained in occupational medicine in remote geographic areas where many hazardous waste sites are located. If an occupational health physician is not available, the site medicel program may be managed, and relevant examinetions performed, by a local physician with assistance from an occupationa! medicine consultant. These functions may also be performed by a qualified Registered Nurse, preferably an Occupational Health Nurse, under the direction of a suitably qualified physician who has responsibility for the program!

All medical test analyses should be performed by a laboratory that has demonstrated satisfactory performance in an established interlaboratory testing program [1]. The clinical or diagnostic laboratory to which samples are sent should meet either (1) minimum requirements under the Clinical Laboratories Improvement Act of 1967 (42 CFR Part 74 Subpart M Section 263[a]\}, or (2) the conditions for coverage under Medicare. These programs are administered by the Health Care Financing Administration (HCFA), U.S. Department of Health and Human Services (DHHS).

A site medical program should provide the following components:

- Surveillanco:

Pre-employment screening.

Periodic medical examinations (and followup examinations when appropriate).

Termination examination.

- Treatment:

Emergency

Non-emergency (on a case-by-case basis)

- Recordkeeping.

- Program review.

Table 5-1 outlines a recommended medical program; screening and examination protocols are described in the following sections. These recommendations are based on known health risks for hezardous waste workers, a review of available data on their exposures, and an assessment of several established medical programs. Because conditions and hazards vary considerably at each site, only general guidelines are given.

The effectiveness of a medical program depends on active worker involvement. In addition, management should have a firm commitment to worker health and

\footnotetext{
1 Cortified, state-licensed (where required) Physician's Assistent may also perform these examinations if a physician is ovailable on the premises.
} 
Tablo 5-7. Recommended Medical Program

\begin{tabular}{|c|c|c|}
\hline COMPONENT & RECOMMENOEO & OPTIONAL \\
\hline $\begin{array}{l}\text { Pro-Emplowment } \\
\text { Sereming }\end{array}$ & 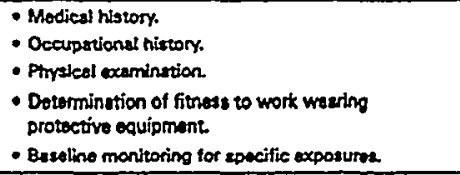 & 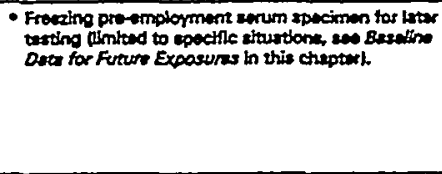 \\
\hline $\begin{array}{l}\text { Perlode Modical } \\
\text { Examlnations }\end{array}$ & 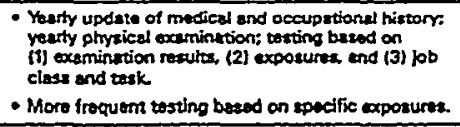 & - Yerty tostine with routino inodical torts. \\
\hline $\begin{array}{l}\text { Emorgency } \\
\text { Trestmont }\end{array}$ & 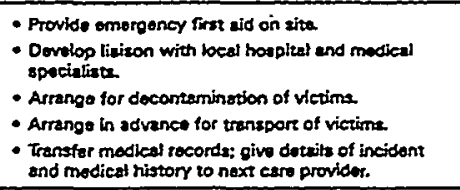 & \\
\hline $\begin{array}{l}\text { Hon-Emergency } \\
\text { Trestrmant }\end{array}$ & $\begin{array}{l}\text { - Develop mochanizm for non-amergoncy hoatth } \\
\text { care. }\end{array}$ & \\
\hline $\begin{array}{l}\text { Recordikenping and } \\
\text { Revtow }\end{array}$ & 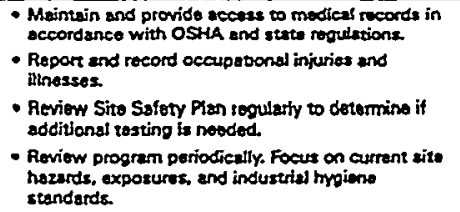 & \\
\hline
\end{tabular}

safoty, and is encouraged to express this comrnitment not only by modical sunviliance and veatmont, bus also through management directives and informal encouragoment of employees to maintain good health through exercisa, proper diet, and evoidance of tobacca, sicchol abuse and drug sbuse in particulas, manogement should:

- Urge prospective employees to provide o complete and datrilad occupational and modical history.

- Assuro employees of confidentiality.

- Require workers to report eny suspected exposures. regardlass of degree.

- Require workers to bring any unusual physical or psychological conditions to the physicisn's sttention. Employes training should emphasizo that vagus disturbances or apperently minor complaints lsuch as sxin irritation or hasdachesl may bo importent.

When doveloping an individual program, sito condittons must be considered and the monitoring nesds of esch worker should be determined based on the worker's medleal and occupstional history, as woll as current and potential exposures on site. The routine job tasks of esch worker should be considered. For instance s hesry equip mont oporator boconat to sianificant noise lowels would ment oporator exposed to slanteam noise lovels would roquire different monitorisg protocol from a fieid sam edministretor mixy only noed a pre-amployment screening for ability to wear porsonal protective equipment-if this is an occasional requitemem-rather then a more compre hensive program.

The potantial exposures that may oceur at a stico muat also be considered. Whito it is often impossible to identify every toxic subrtancs that wists at exch hazardous waste elte certein typos of hazerdous zubstances or chemicals ere more llkoly to be present than othere. Some of thees are:

- Aromatic hydrocstors.

- Asbearos for asbertiform partclase.

- Diaxir.

- Halogenated ellphatic Mydrocerbons.

- Hoavy metala.

- Hetbicides.

- Orgenochlocine insecticider.

- Orgenophosphate and carbarnato inascticides.

- Polychlorinated biphamyls (PCEs).

Tablo 5-2 list these groups, with representutive com poundr, uares henith offocts, and evallable medices monitoring procodurte. 
5ib 5-2. Common Chemical Toxicants Found at Hazardous Waste Sites, Thair Health Effects and Madical Monitoring

\begin{tabular}{|c|c|c|c|c|c|}
\hline $\begin{array}{l}\text { HUARDOUS } \\
\text { EUSTIANCE } \\
\text { ON CHEMICAL } \\
\text { GHOUP }\end{array}$ & COMPOUNDS & USES & TARGET ORGANS & POTENTIAL HEALTH EFFECTS & MEDICAL, MONITORING \\
\hline $\begin{array}{l}\text { Aromatic } \\
\text { Hrdrocembons }\end{array}$ & $\begin{array}{l}\text { Benzene } \\
\text { Ethyl benzene } \\
\text { Toluene } \\
\text { Xylene }\end{array}$ & $\begin{array}{l}\text { Commercial } \\
\text { solvents and } \\
\text { intermediates for } \\
\text { synthesis in the } \\
\text { chemical and } \\
\text { pherrnaceutical } \\
\text { industries. }\end{array}$ & $\begin{array}{l}\text { Blood } \\
\text { Bone marrow } \\
\text { CNS } \\
\text { Eyes } \\
\text { Respiratory } \\
\text { system } \\
\text { Skin } \\
\text { Liver } \\
\text { Kidney }\end{array}$ & $\begin{array}{l}\text { All cause: } \\
\text { CNS' depression: decreased } \\
\text { alertness, hesdache, sleepi- } \\
\text { ness, loss of consciousness. } \\
\text { Defatting dermatitis. } \\
\text { Benzene suppresses bone- } \\
\text { marow function, causing } \\
\text { blood changes. Chronic } \\
\text { exposure con cause leukemis. } \\
\text { Note: Because other aromatic } \\
\text { hydrocarbons may be contami- } \\
\text { nated with benzene during dis- } \\
\text { tillation, benzene-related health } \\
\text { effocts should be considered } \\
\text { when oxposure to any of these } \\
\text { agents is suspected. }\end{array}$ & $\begin{array}{l}\text { Occupational/general } \\
\text { medical history } \\
\text { emphasizing prior } \\
\text { exposure to these of } \\
\text { other toxic agents. } \\
\text { Medical examination } \\
\text { with focus on liver, kid. } \\
\text { noy, nervous system, } \\
\text { and skin. } \\
\text { Lobototory testing: } \\
\text { CBct } \\
\text { Platelet count } \\
\text { Measurement of kidney } \\
\text { and liver function. }\end{array}$ \\
\hline $\begin{array}{l}\text { Asbestos lor } \\
\text { axbestform } \\
\text { perticles] }\end{array}$ & - & $\begin{array}{l}\text { A variaty of } \\
\text { industrial uses, } \\
\text { including: } \\
\text { Building } \\
\text { Construction } \\
\text { Cement work } \\
\text { Insulation } \\
\text { Fireproofing } \\
\text { Pipes and } \\
\text { ducts for } \\
\text { water, air, and } \\
\text { chamicals } \\
\text { Automobile } \\
\text { brake pads } \\
\text { and linings }\end{array}$ & $\begin{array}{l}\text { Lung8 } \\
\text { Gastrointestinal } \\
\text { system }\end{array}$ & $\begin{array}{l}\text { Chronic offects: } \\
\text { Lung cancer } \\
\text { Mesothelioms } \\
\text { Asbestosis } \\
\text { Gastrointestinal malignancies } \\
\text { Asbestos exposure coupled } \\
\text { with cigarette smoking has } \\
\text { been shown to have a } \\
\text { synergistic effoct in the } \\
\text { development of lung cancer. }\end{array}$ & $\begin{array}{l}\text { History and physical } \\
\text { examination should } \\
\text { focus on the lungs and } \\
\text { gastrointestinal system. } \\
\text { Laboratory tosts should } \\
\text { include a stool test for } \\
\text { occult blood evaluation } \\
\text { as a check for possible } \\
\text { hidden gastrointestinal } \\
\text { malignancy. } \\
\text { A high quality chost } \\
\text { X-roy and pulmonary } \\
\text { function test may help } \\
\text { to identify long-term } \\
\text { changes associated } \\
\text { with asbestos diseases; } \\
\text { however, oasty identifi- } \\
\text { cation of low-doso } \\
\text { exposure is unlikely. }\end{array}$ \\
\hline $\begin{array}{l}\text { loxin (see } \\
\text { erbicides) }\end{array}$ & & & & & \\
\hline $\begin{array}{l}\text { Halogenated } \\
\text { Aliphutic } \\
\text { tydrocarbons }\end{array}$ & $\begin{array}{l}\text { Carton } \\
\text { tetrachloride } \\
\text { Chloroform } \\
\text { Ethyl bromide } \\
\text { Ethyl chloride } \\
\text { Ethylene dibromide } \\
\text { Ethylene dichloride } \\
\text { Methyl chloride } \\
\text { Methyl chlorolorm } \\
\text { Methylene chloride } \\
\text { Tetrachloroethane } \\
\text { Tetrachloroethylene } \\
\text { (perchloroethylene) } \\
\text { Trichloroethylene } \\
\text { Vinyl chloride }\end{array}$ & $\begin{array}{l}\text { Commercial } \\
\text { solvents and } \\
\text { intermediates in } \\
\text { organic } \\
\text { synthesis. }\end{array}$ & $\begin{array}{l}\text { CNS* } \\
\text { Kidney } \\
\text { Liver } \\
\text { Skin }\end{array}$ & $\begin{array}{l}\text { All cause: } \\
\text { CNS• depression: decreased } \\
\text { alertness, headaches, } \\
\text { sleepiness, loss of } \\
\text { consciousness. } \\
\text { Kidney changes: decreased } \\
\text { urine flow, swelling } \\
\text { (espocially around eyes). } \\
\text { anemie. } \\
\text { Liver changes: fotigue. } \\
\text { malaise. dark urine, liver } \\
\text { enlargement, jaundice. } \\
\text { Vimyl chloride is a known } \\
\text { carcinogen: soveral others in } \\
\text { this group are potential } \\
\text { carcinogens. }\end{array}$ & $\begin{array}{l}\text { Occupational/general } \\
\text { medical history } \\
\text { emphesizing prior } \\
\text { exposure to these or } \\
\text { other toxic agents. } \\
\text { Medical examination } \\
\text { with focus on liver, } \\
\text { kidnoy, nervous system, } \\
\text { and skin. } \\
\text { Laboratory tosting for } \\
\text { liver snd kidney } \\
\text { function: carboxyhemo- } \\
\text { globin where relovant. }\end{array}$ \\
\hline
\end{tabular}


Tuble 5-2. (cont.)

\begin{tabular}{|c|c|c|c|c|c|}
\hline $\begin{array}{l}\text { HNZARDOUS } \\
\text { SUBSTANCE } \\
\text { OR CHEMICAL } \\
\text { GROUP }\end{array}$ & COMPOUNDS & USES & TARGET ORGANS & POTENTLAL HEALTH EFFECTS & MEDICAL MONITORING \\
\hline Howry Motels & $\begin{array}{l}\text { Aseanic } \\
\text { Beryllium } \\
\text { Cedmium } \\
\text { Chromium } \\
\text { Losd } \\
\text { Mercury }\end{array}$ & $\begin{array}{l}\text { Wide variaty of } \\
\text { lndurtrial and } \\
\text { commercial } \\
\text { User. }\end{array}$ & $\begin{array}{l}\text { Multiple organs } \\
\text { ond syotoms } \\
\text { inchuding: } \\
\text { Blood } \\
\text { Cardiepulmonery } \\
\text { Gestrointestinal } \\
\text { Kidner } \\
\text { Uver } \\
\text { Lung } \\
\text { CNSe } \\
\text { Skin }\end{array}$ & 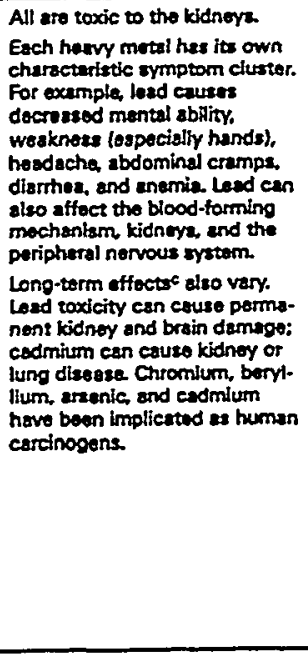 & 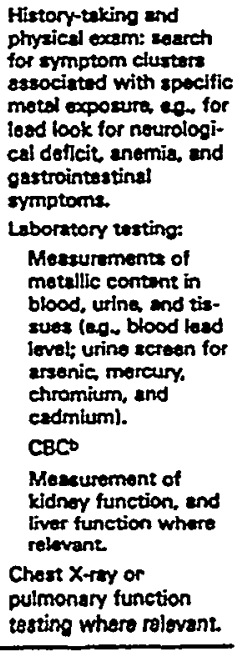 \\
\hline Herbleteles: & $\begin{array}{l}\text { Chlorophenoxy } \\
\text { compournds: } \\
\text { 2,4-dichloro- } \\
\text { phonoxyacetic } \\
\text { scid }(2,4-D) \\
2,4,5 \text {-trichloro- } \\
\text { phonoxyacetic } \\
\text { acid }(2,4,5-1) \\
\text { Dioxin (tetrachloro- } \\
\text { dibenzo-p-dioxin, } \\
\text { TCoD), which } \\
\text { occurs as a tracs } \\
\text { contaminamt in } \\
\text { these compounds. } \\
\text { poses the most } \\
\text { serious health risk. }\end{array}$ & $\begin{array}{l}\text { Vegetation } \\
\text { control. }\end{array}$ & $\begin{array}{l}\text { Kidney } \\
\text { Liver } \\
\text { CNS: } \\
\text { Skin }\end{array}$ & 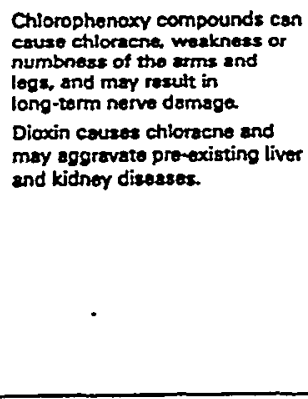 & $\begin{array}{l}\text { History and physical } \\
\text { ocam should focus on } \\
\text { the skin and nervous } \\
\text { system. } \\
\text { Laborstory tests } \\
\text { inelude: } \\
\text { Moasurement of liver } \\
\text { and kidney function. } \\
\text { where relevant. } \\
\text { Uhirslysic. }\end{array}$ \\
\hline $\begin{array}{l}\text { Orgenoctiorino } \\
\text { insecticides }\end{array}$ & $\begin{array}{l}\text { Chlorinated } \\
\text { othenes: } \\
\text { DDT } \\
\text { Cyelodienes: } \\
\text { Aldrin } \\
\text { Chlordene } \\
\text { Dieldiln } \\
\text { Endrin } \\
\text { Chlorocyelobexenes: } \\
\text { Lindane }\end{array}$ & Pest control. & $\begin{array}{l}\text { Kidnoy } \\
\text { Liver } \\
\text { CNS* }\end{array}$ & 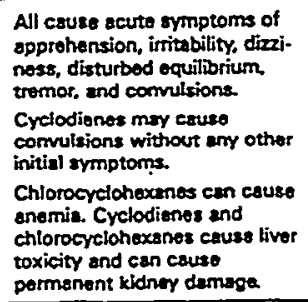 & $\begin{array}{l}\text { History and phraical } \\
\text { exam should focus on } \\
\text { the nervous systam. } \\
\text { Lboratory tests } \\
\text { include: } \\
\text { Messurement of } \\
\text { kidnoy and liver } \\
\text { function. } \\
\text { CBCb for exposuro to } \\
\text { chlorocyclohexenes. }\end{array}$ \\
\hline
\end{tabular}


Table 5-2. (cont.)

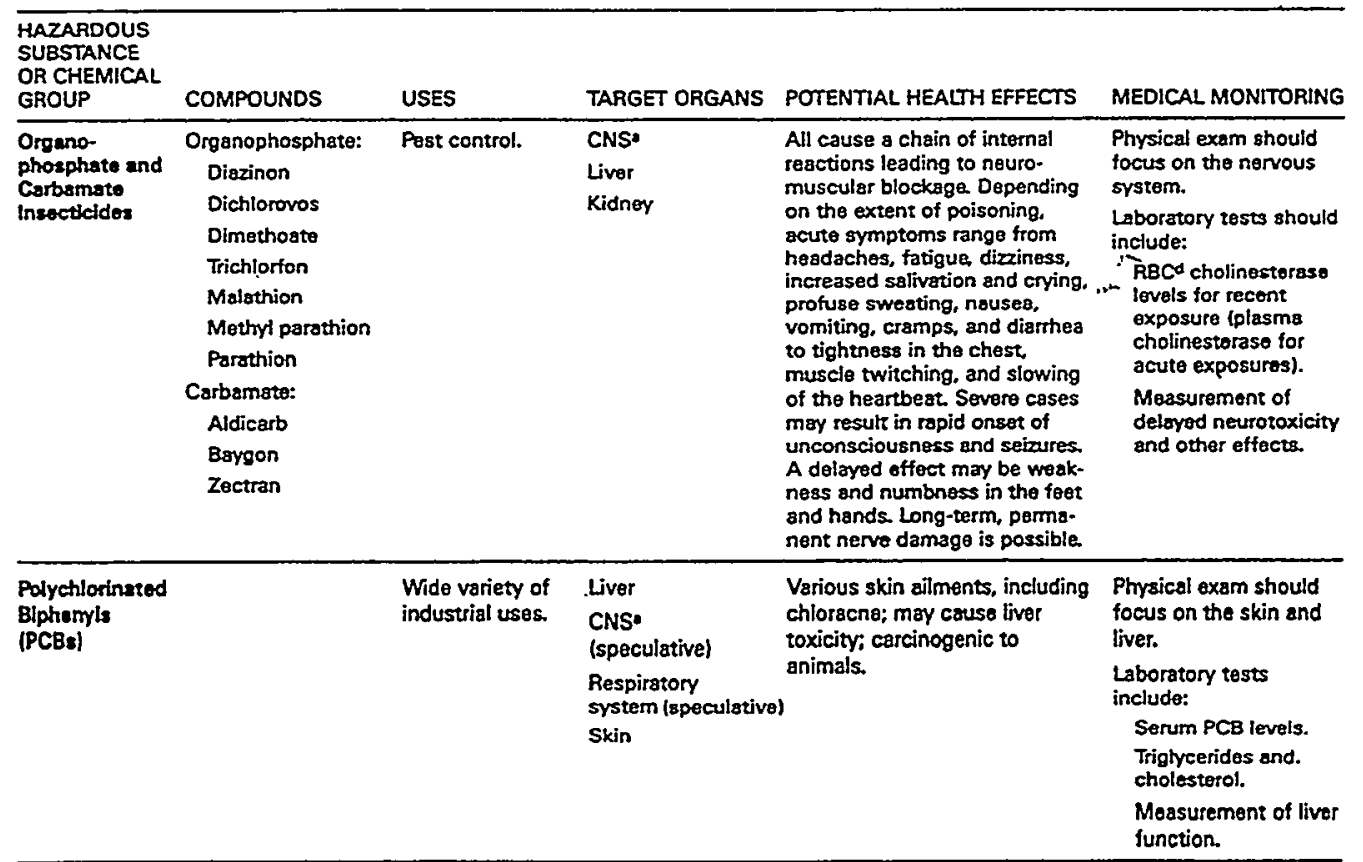

CNS = Central nervous system.

clong-term offects generally manifest in 10 to 30 years.

बRBC = Red blood count.

In compiling a testing protocol, bear in mind that standard occupational medical tests were developed in factories and other enclosed industrial environments, and were based on the presence of specific identifiable toxic chemicals and the possibility of a significant degree of exposure. Some of these tests may not be totally appropriate for hazardous waste sites, since available data suggest that site workers have low-level exposures to many chemicals concurrently, plus brief high-level exposure to some chemicals [2]. In addition, most testing recommendations, even those for specific toxic substances, have not been critically evaluated for efficacy.

Another important factor to consider is that risk can vary, not only with the type, amount and duration of exposure, but also with individual factors such as age, sex, weight. stress, diet, susceptibility to allergic-type reactions, medications taken, and offsite exposures (eg., in hobbies such as fumiture refinishing and automotive body work).

\section{Pro-Employment Screening}

Pre-amployment screening has two major functions: (1) determination of an individual's fitness for duty, including the ability to work while wearing protective equipment, and (2) provision of baseline data for comparison with future medical data. These functions are discussed below. In addition, a sample pre-mployment examination is described.

\section{Determination of Fitnese for Duty}

Workers at hazardous waste sites are often required to perform strenuous tasks (e.g., moving 55-gallon drums) and wear personal protective equipment, such as respirators and protective clothing, that may cause heat stress and other problems (see Chapter $\mathbf{8}$ for details). To ensure that prospective employees are able to meet work requirements, the pre-employment screaning should focus on the following areas:

\section{Occupational and Medical History}

- Make sure the worker fills out an occupational and medical history questionnaire. Review the questionnaire before seeing the worker. In the exemining room, discuss the questionnaire with the worker, paying special attention to prior occupationa exposures to chemical and physical hazards.

- Review past illnesses and chronic disesses, particularly atopic diseases such as bczema and asthma, lung diseases, and cardiovascular disease. 
- Roviow symptoms, especially shortness of breath or labored breathing on exertion, other chronic respiratory symptoms, chest pain, high blood pressure, and hest intolerance.

- Identify individuals who are vulnerable to particular substances (ag., someone with a history of severe asthmatic reaction to a spocific chemical).

- Rocord relevant lifestylo habits (eg., cigarette smoking, alcohol and drug use) and hobbies.

Ptrpalcal Examination

- Conofuct a comprehensivo phrsical examination of all body orgens, focussing on the pulmonary. cardiovascular, and musculoskelotal systems.

- Noto conditions that could increase susceptibility to heat stroke, such as obesity and lack of physicol exercisa.

- Note condlitions that could affect respirator use, such as missing or arthritic fingers, facial scers, dentures, poor eyesight; or perforated ear drums.

Ability to Work While Waaring Protective Equipmant [3] - Disqualify individuals who are clearly uriable to perform based on the medical history and physical exem (eg., those with severe lung disease, heart disease, or back or orthopedic problems).

- Note limitations concerning the worker's ability to use protective equipment (ag.e individuals who must wear contact lenses cannot wear full. facepiece respirators\}.

- Provide additional testing (eq., chest X-ray, pulmonary function teating, electrocandiogram\} for ability to wear protective equipment where necessary.

- Base the determination on the individual worker's profile lag., medical history and physical exem. age, provious exposures and testing).

- Make a written essessment of the worker's capscity to perform while wearing a respirator, if wear- ing a respirator is a job requirement. Note that the Occupational Safety and Health Adroinistration (OSHA) respirator standard (29 CFR Part 1910.134) states that no employee should be assigned to a task that requires the use of a respirator unless it has been determined that the person is physically able to perform under such conditions.

\section{Basaline Data for Future Expostre:}

Pro-employmem screening can be used to establish baseline date to subsequently verify the efficacy of protective measures and to later determine if exposures have adversely affected the worker. Baseline testing may include both medical screening tests and bjologic monitoring tests. The latter (e.e., blood lead level) may be useful for ascertaining pre-exposure lovels of specific substences to which the worker may be exposed and for which reliable tests are available. Given the problem in prodicting significant exposures for these workers, there are no clear guidelines for prescribing speclfic tests. The following approach identifies the types of tests that may be indicated:

- A battery of tests based on the worker's past occupational and medical history and an assessment of significant potential exposures. See Table 5-3 for examples of tests frequently performed by occupational physicians.

- Standard established testing for specific toxicants in situations where workers may receive significant exposures to these agents. For example, long-term exposura during cleanup of a polychiorinsted biphenyis (PCB) waste facility can be monitored with pro-employment and periodic serum PCB testing [4]. Standard proceduras are available for determining levels of ather substances, eg. lead, cadmium, arsenic, and organophosphate pesticides.

- Where applicable pro-employment blood specimens and serum frozen for later testing. (PCBs and some pesticides are examples of agents amenable to such monitoring.)

Tuble 5-3. Tests Frequently Performed by Occupational Physicians

\begin{tabular}{|c|c|c|}
\hline FUNCTION & TEST & EXAMPLE \\
\hline $\begin{array}{l}\text { Lwer: } \\
\text { Centural } \\
\text { Obetruetion } \\
\text { Cex Injery }\end{array}$ & $\begin{array}{l}\text { Blood tests } \\
\text { Enzyme test } \\
\text { Enzyme toste }\end{array}$ & 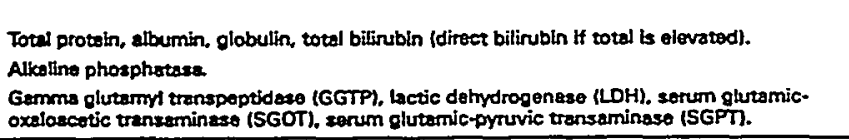 \\
\hline Codner: & Blood tests & Blood uroa nitrogen (BUN), crestinine, uric acid. \\
\hline $\begin{array}{l}\text { Multpio } 8 \text { retams } \\
\text { and Ongans }\end{array}$ & Urinalyis & $\begin{array}{l}\text { Including color, appearance; specific gravthy pH; qualitative glucose, protein, bile, and aco- } \\
\text { tone; occult blood; microscopic examination of centrifuged sediment }\end{array}$ \\
\hline 8loodforming Function & Blood rests & 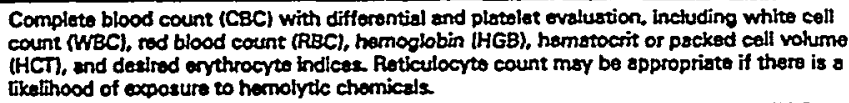 \\
\hline
\end{tabular}




\section{Sample Pro-Employment Exemlnation}

Occupational and Modical History

- Do a complete medical history emphasizing these systems: nervous, skin, lung, blood-forming, cardiovascular, gastrointestinal, genitourinary, reproductive ear, nose, and throat.

Physical Examination

Inciude at least the following:

- Height, weight, temperature, pulse, respiration, and blood pressure.

- Head, nose, and throat.

- Eyes. Include vision tests that measure refraction, depth perception, and color vision. These tests should be administered by a qualified technician or physician. Vision quality is essential to safety, the accurate reading of instruments and labels, the avoidance of physical hazards, and for appropriate response to color-coded labels and signals.

- Ears. Include audiometric tests, performed at 500. $1,000,2,000,3,000,4,000$, and 6.000 hartz $(\mathrm{Hz})$ pure tone in an approved booth (see requirements listed in 29 CFR Part 1910.95, Appendix D). Tests should be administered by a qualified technician, and results read by a certified audiologist or a physician familiar with audiometric evaluation. The integrity a revish orforated eardrums can provide a route of entry for chemical into the body. The ptrysician ovaluating employees with perforated eardrums should consider the emvironmental conditions of the job and discuss possible specific safety controls with the Site Safety Officer, industrial hygienist, and/or other health professionals before deciding whother such individuals can safely work on site

- Chest (heart and lungs).

- Poripheral vascular system.

- Abdomen and rectum (including hernia exam).

- Spine and other components of the musculoskeletal system.

- Genitourinary system.

- Skin.

- Nervous system.

Thets

- Blood.

- Urine

- A $14 \times 17$-inch posterior/anterior view chest X-ray, with fateral or oblique views only if indicated or if mandazed by state regulations. The $X$-ray should be taken by a certifiad radiology technician end interpreted by a board-certified or board-eligible radiol. ogist. Chest $X$-rays taken in the last 12-month period. as well as the oldest chest $X$-ray available, should be obtained and used for comparison. Chest $X$-rays should not be repeated more than once a year, unless otherwise determined by the examining physicien.

Abrity to Perform While Wearing Protective Equipment To determine a worker's capacity to perform while wear- ing protective equipment, additional tests may be neces. sary, for example.

- Pulmonary function testing. Measurement should include forced expiratory volume in 1 second (FEV) forced vital capacity (FVC), and FEV 1 - to-FVC ratio, with interpretation and comparison to normal predicted values corrected for age, height, race, and sex. Other factors such as FEF, MEFR, MVV, FRC, RV and TLC' may be includad for additional information. A permanent record of flow curves should be placed in the worker's medical records. The tests should be conducted by a certified technician and the results interpreted by a physician.

- Electrocardiogram (EKG). At least one standard 12 -lead resting EKG should be performed at the discretion of the physician. A "stress test" Igraded exercise) may be administered at the discretion of the examining physician. particularly where heat stress may occur.

\section{Baseline Monitoring}

If there is likelihood of potential onsite exposure to a particular toxicant, specific baseline monitoring should be performed to establish data relating to that toxicant.

\section{Periodic Medical Examinations}

\section{Poriodic Screening}

Pariodic medical examinations should be developed and used in conjunction with pre-employment screening examinations. Comparison of sequential medical reports with baseline data is essential to determine biologic trends that may mark early signs of adverse health effects, and thereby facilitate appropriate protective measures.

The frequency and content of examinations will vary, depending on the nature of the work and exposures. Generally, medical examinations have been recommended at least yearly. More frequent examinations may be necessan, depending on the extent of potential or actual exposure, the type of chemicals involved, the duration of the work assignment, and the individual worker's profile For example, workers participating in the cleanup of a PCB-contaminated building were initially examined monthly for serum PCB levels. Review of the data from the first few months revealed no appreciable evidence of PCB exposure. The frequency of PCB testing was then reduced [4]. Periodic screening exams can include:

- Interval medical history, focusing on changes in health status, illnesses, and possible work-related symptoms. The examining physician should have information about the worker's interval exposure his tory, including exposure monitoring at the job site, supplemented by worker-reported exposure history and general information on possible exposures at previously worked sites.

- Physical examination.

- FEF - forced expiratory flow; MEFR = maximal expiratory flow rate; $M V V=$ maximal woluntary ventilation; $F R C=$ unctional residual cepacity; RV = residual volume: TLC = totsl lung capacity 
- Additional medical testing, depending on available exposure information, modical history, and exsminstion results. Testing should be specific for the passible medicel effects of the warker's exposure Multiple testing for a large renge of potential exposures is not always useful; it moy involve invaexposures is not always useful; it moy involve inva-

sive procedures leg, tissue biopsyl, be expensive.
and may produce false-positive results.

Pulmonary function tests should be administered if the individual uses a respirator, has been or may be exposed to irtitating or toxic substances, or if the individual has breathing difficulties, especially when wearing a respirstor.

Audiometric tosts. Annual retests are required for personnel subject to high noise exposures ten

8-hour, imo-weighted average of B5 dBA' or more) those required to wear hearing protection, or as otherwisa indicated.

Vision tests. Annual retests are recommended to check for vision degradation.

Blood and urine tosts when indicated.

8ample Puriodic Medleal Examination

The basic periodic medical examination is the same as the pre-employment screening (see previous section. Sample Pre-Employment Examination), modified according to current conditions, such as chenges in the worker's symptoms, site hazards, or exposures.

\section{Termination Examination}

At the end of amployment at a hazardous waste site, all personnel should have a medical examination es described in the previous sections (see Sample ProEmployment Examination). This examination may be limited to obtaining an interval medical history of the period since the last full examination (consisting of medical history, physical examination, and laboratory tests) if all three following conditions are mot:

- The last full medical examinarion was within the last 6 months

- No.exposure occurred since the last examination.

- No symptoms associated with exposure cccurred since the last examination.

If any of these criteria are not met, a full examination is medjcally necessary at the termination of employment.

\section{Emergency Treatment}

Provisions for emergency treatment and acute nonemergency veatment should be made at each site Preplanning is vital.

When developing plans, procedures, and equipment lists. the range of actual and potential hazards specific to the site should be considered, including chemical, physical (such as heat and/or cold stress, falls and trips), and biologic hazards (animal bites and plent poisoning as well as hazardous biological wastes). Not only site workers, but

OBA = docibeis on A weighted scaks (29 CFR Pan 1910.95) also contractors, visitors, and other personnel (particularly firefighters) may require emergency treatment.

Emergency medical treatment should be integrated with the overafl site emergency response program (see Chapter 12). The following are recommended guidelines for establishing an emergency treatment program.

- Irain a team of site personnel in emergency first aid. This should include a Red Cross or equivalent certified course in cardiopulmonary resuscitation (CPR) and first-aid training that emphssizes treatment for explosion and bum injuries, heat stress, and acure chemical toxicity in addition, this team should chemical roxicity. In addion. this coam should inciude an emergency medical technician (EMT) possible. Table 5-4 lists signs and symptoms of exposure and heat

- Train personnel in emergency decontamination procedures in coordination with the Emergency Response Plan (see Chapter 12 tor details).

- Predesignate roles and responsibilities to be assumed by personnel in an emergency.

- Establish an emargency/first-aid station on site, capable of providing (1) stabilization for patients requiring offsite treatment, and (2) general first aid leg., minor cuts, sprains, abrasionsl.

Locata the station in the clean area adjacent to the decontamination area to facilitate emergency decontamination.

Provide a standard first-eid kit or equivalent supplies, plus additional items such as emergency/del. uge showers. stretchers, portable water, ice. emergeney eyewash, decontamination solutions. and fire-extinguishing blankets.

Restock supplies and equipment immedietely after each use and check them regularly.

- Arrange for a physician who can be paged on a 24-hour basis.

- Setup an on-call team of medical specialists for emergency consultations, eg.. a toxicologist dermatologist, hematologist, allergist, opthalmologist. cardiologist, and neurologist

- Establish a protocol for monitoring heat stress (see Monitoring section of Chapter 8).

- Make plans in advance for emergency transportation to, treatment at, and contamination control procedures for a nearby medical facility.

Educate local emergency transport and hospital personnel about possible medical problems on site; types of hazards and their consequences: potential for exposure: scope and function of the site medical program.

Assist the hospital in developing procedures for site-related emergencies. This will help to protect hospital personnel and patients, and to minimizs delays due to concerns about hospital safety or contamination.

For specific illnesses or injuries, provide details of the incident and the worker's past medical history to the appropriate hospital staff. This is especially crucial when specific medical treatment is reouired. eq. for exposure to cyanide or organophosphate pasticides 
Tuble 8-4. Signs and Symptoms of Cherrical Exposure and Hoat Stress that Indieate Potential Medical Emergencies

\begin{tabular}{|c|c|}
\hline TYPE OF MAZARD & SHGNS ANO SYMPTOAS \\
\hline Chamical Harand & 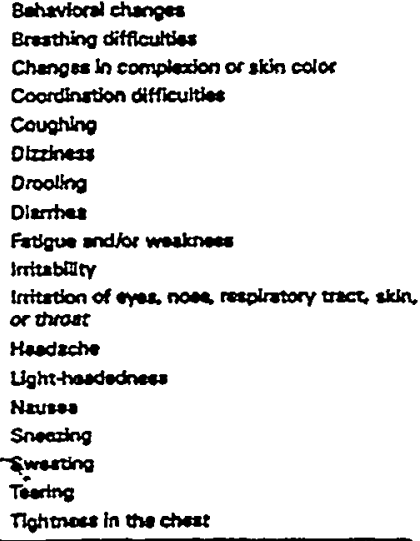 \\
\hline Hatt Exhaution & 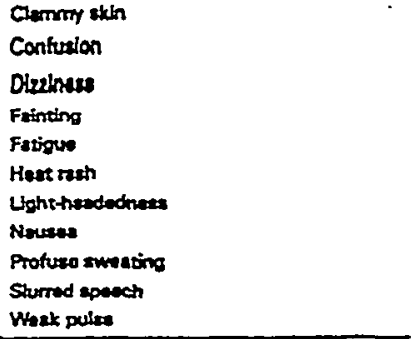 \\
\hline $\begin{array}{l}\text { Meart sootal } \\
\text { imey bo fotall }\end{array}$ & 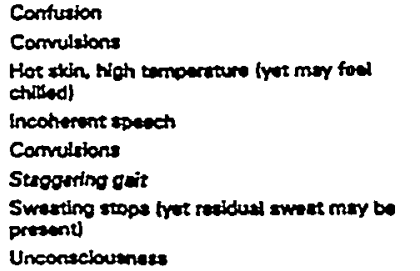 \\
\hline
\end{tabular}

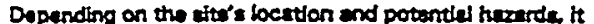
min be importent to identfy additiond medicel fecillties capsble of sophistiented response to chemied or other exposuret.

- Pest contpicuousty fwith dupllentea near the twie phones) the numear, phone numbers, addreacere. and procedures for contecting

On-call phyteciens.

Modical speclelists.

Ambulances services.

Mectied fecilitytien).

Emergency, fire and poitce servicas.

Poison control hotione.

- Provide mape and directora.

- Mike zure at leest all managere and al individuats imolved in medicel response know the way to the coenest emergenor modled facibty

- Establich a rediocommunicetion syatern for emergency use

- Review emergency procedures deily with ell ette poreansal at sofety meatings before beglnoing the work shitt.

\section{Non-Emergency Treatment}

Amengenente thould bo made for non-mergency medcal cur for havedous warts cits worken who en

oxperiencing heslth effects resultho from en expoure to hecerdous substances in coritunction whth the medical surviltence proprem, offitt medical curs should mours

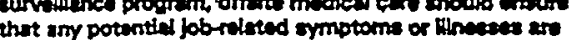

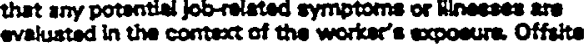
medical perconnel ahould aleo imverdgets end treat nonjob-ralated iknesees that mey pur the urorter at riak beceuse of task requinemente (ea, a bed cold of fil thet might kntertere with resplirator uea). A copy of the worker's medleal records stouid be knpt at the with (with provisions tor securty and confidentinilty) and, when eppropriate at a nearby hospital. Inenting phyalelens should hive scceses to these reconde.

\section{Medical Records}

Proper recondicenping is eacentiel at hareardous waxto situs becuuse of the nature of the work and rister emplopees mor work ot a large number of geographically

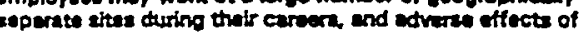
long-term exposure miny not become epperent tor mimry yeere. Records enable eubequert modical cure providers to be informed about workers' previous end carrem exposuras.

Occupstionst Safety and Hasith Administration (OSHA) regulmions mandito thrt unleas a specifle occuprotion safury and hasith reanderd provides a difform time period, the emptoyer must:

- Muintain and preserva modical records an exposed worters for 30 yest efter ther larve employment (29 CFR Part 1810.20). 
- Make available to workers, their authorized representatives, and authorized OSHA representatives the results of medical testing and full medical records and analyses (29 CFR Part 1910.20).

- Maintain records of occupational injuries and iflnesses and post a yearly summary report 129 CFR Part 1904).

\section{Program Review}

Regular evaluation of the medical program is important to ensure its effectiveness. Maintenence and review of medical records and test results aid medical personnel, site officers, and the paremt company and/or agency managers in assessing the effectiveness of the health and safety program. The Site Safoty Officer, medical consultant. and/or menagement representativa should, at least annually:

- Ascertain that each accident or illness was promptly investigated to determine the cause and make necessary chenges in health and safety procedures.

- Evaluate the efficacy of specific medical testing in the context of potential site exposures.

- Add or delete medical tests as suggested by current industrial hygione and emvironmontal dato.

- Review potential exposures and Site Safety Plans at all sites to determine if additional testing is required.

- Review emergency.treatment procedures and update lists of emergency contacts.

\section{References}

1. Proficiency Testing Programs

Division of Technology Evaluation and Assistance

Laboratory Program Office

Center for Disease Contro

Atlanta, GA 30333

College of Americen Pathologists

7400 N. Skokis Blvd.

Skokie, IL 60077

American Association for Bioanalysts

205 W. Lever Street

Brownsville, TX 78520

2. Costello, R.J. 1983. U.S. Environmental Protection Agency Triangle Chemical Site, Bridge City, Texes. NIOSH Heatth Hazard Evaluations Determination Report, HETA 83-417-1357.

3. ANSI. 1984. American National Standard for Respiratory Pratection. ANSI.288.6-1984. American National Standards Institurte, 1430 Broadway, Now York, NY 10018.

4. Gleit, A.; Cohen, A.G.; Chase, K.H.; and J. Toth. 1985. Summary Report of the Medical Surveillance Program for the Binghamton Stete Office Building Decontamination Project. Prepared for Versar Now York, Inc 


\section{INFORMATION SHEET \\ DOES 29 CFR 1910.120 APPLY TO THE \\ CHEMICAL STOCKPILE EMERGENCY PREPAREDNESS PROGRAM? (CSEPP)}

\section{Who is the Intended Audience?}

The intended audience for this information sheet are those individuals who may participate in an organized emergency response activity as a result of a Chemical Stockpile Emergency Preparedness Program (CSEPP) chemical release. These individuals may need to increase their basic knowledge and understanding of the 29 Code of Federal Regulations (CFR) 1910.120 Hazardous waste operations and emergency response (HAZWOPER) standard, especially in terms of its applicability to CSEPP.

\section{What is the Chemical Stockpile Emergency Preparedness Program (CSEPP)?}

CSEPP is a community emergency preparedness program complementing the Department of Defense's initiative to destroy domestic stockpiles of aged chemical warfare agent munitions. Recognition by the U.S. Army that the potential threat to the public from continued storage of chemical agent munitions was greater than the threat from the transportation and demilitarization gave rise to the CSEPP. CSEPP has established a concept of operations and work rules for CSEPP participants which govern response to an accident/incident involving a release of chemical warfare agents on one of the eight military installations storing the agents in the continental U.S.

CSEPP response actions will be limited to actions off the military installation (i.e., offsite or off-post) that protect the civilian general population or public. CSEPP participants involved in the off-post response will perform a limited variety of functions, including controlling evacuation traffic, providing emergency medical services, and performing emergency decontamination. Although contact with off-post areas potentially contaminated with chemical agent is to be avoided where possible, assignments within such areas may be necessary to protect the public. To provide protection in the event of entry into contaminated areas, participants identified in CSEPP emergency response plans will be issued PPE appropriate for the situation. 


\section{Is the HAZWOPER Standard (1910.120) Applicable to CSEPP?}

The HAZWOPER standard covers the following operations:

- Clean-up operations required by a governmental body at uncontrolled hazardous waste sites (e.g., National Priority Site List);

- Corrective actions involving clean-up operations at Resource Conservation and Recovery Act (RCRA) regulated sites;

- Voluntary clean-up operations at sites recognized by governmental bodies as uncontrolled hazardous waste sites;

- Operations involving hazardous wastes at RCRA regulated treatment, storage, and disposal (TSD) facilities; and

- Emergency response operations.

CSEPP participants will not be performing clean-up operations at uncontrolled hazardous waste sites, corrective actions at RCRA regulated sites, or operations at RCRA regulated TSD facilities. The only operation that applies to CSEPP is emergency response operations.

\section{What are Skilled Support Personnel?}

On July 6, 1995, the Occupational Safety and Health Administration (OSHA) released an Administrative Interpretation for Tooele, Utah, which stated that CSEPP participants are skilled support personnel. According to 1910.120 (q) (4), skilled support personnel are described as follows.

Personnel, not necessarily an employer's own employees, who are skilled in the operation of certain equipment, such as mechanized earth moving or digging equipment or crane and hoisting equipment, and who are needed temporarily to perform immediate emergency support work that cannot reasonably be performed in a timely fashion by an employer's own employees, and who will be or may be exposed to the hazards at an emergency response scene, are not required to meet the training required in this paragraph for the employer's regular employees. However, these personnel shall be given an initial briefing at the site prior to their participation in any emergency response. The initial briefing shall include instruction in the wearing of appropriate personal protective equipment, what chemical hazards are involved, and what duties are to be performed. All other appropriate safety and health precautions provided to the employer's own employees shall be used to assure the safety and health of these personnel. 


\section{Training Requirements for Skilled Support Personnel}

According to $1910.120(q)(4)$, all that is required for training is an "initial briefing" which includes instruction in:

- Wearing of appropriate PPE;

- What chemical hazards are involved; and

- What duties are to be performed.

There are no required minimum number hours of initial training and no mention of refresher training requirements.

\section{Medical Surveillance Requirements for Skilled Support Personnel}

There are no specific medical surveillance requirements for skilled support personnel in 1910.120 (q) (4). There are specific medical surveillance requirements for members of an organized and designated HAZMAT team in 1910.120 (q) (9). As CSEPP participants are not part of an organized and designated HAZMAT team, the medical requirements from 29 CFR 1910.134 (Respiratory Standard) are applicable. Please refer to the Information Sheet to Aid in the Understanding of Medical Requirements for Workers Wearing Respiratory Equipment for more information on medical requirements.

\section{PPE Requirements for Skilled Support Personnel}

According to 1910.120 (q) (4), the initial briefing must include instruction in the wearing of appropriate PPE. CSEPP work rules prohibit deployment in an immediately dangerous to life or health (IDLH) or unknown environment. Before CSEPP participants are deployed, the level of contamination will be established by the U.S. Army. CSEPP participants will only be deployed in areas where the level of contamination is known to be within the PPE's (i.e., Level C) protective capabilities.

\section{When Will CSEPP Participants Use PPE?}

CSEPP participants will only use CSEPP approved PPE after the Army has sampled and the level of contamination has been determined. PPE will be used if the work site has any level of contamination greater than the agent worker threshold limit value time weighted average (TLV-TWA) and less than IDLH (or 50 times TWA, whichever is smaller). CSEPP PPE will be worn according to State developed CSEPP work rules. 


\section{Is Low Level Detection Equipment Required?}

The U.S. Army has agreed to make available to each site, Army monitoring teams with low level detection equipment. As a result, there will be no CSEPP deployment into any potentially hazardous areas where the level of contamination has not been established.

\section{What Level of PPE Should Persons Performing Decontamination Tasks Wear?}

The OSHA Inspection Procedures Manual for the HAZWOPER Standard, 29 CFR $1910.120(q)$ states that persons performing decontamination tasks should wear the same level of PPE or one level below the workers they are supporting. All CSEPP participants wear Level C PPE, including people performing decontamination tasks.

\section{Can CSEPP States Choose A Different Level of PPE?}

On July 27, 1994, the Centers for Disease Control and Prevention (CDC) published in the Federal Register (59 FR 38191) the "CDC's Recommendations for Civilian Communities Near Chemical Weapons Depots: Guidelines for Medical Preparedness." In this recommendation, the CDC agreed that the CSEPP approved PPE was in fact satisfactory for the tasks to be performed using the CSEPP work rules. However, the CDC also stated that workers could use "...more protective equipment such as encapsulating suits with supplied air respirators, providing that they have and normally use such equipment in conformity with applicable regulations and can perform their required duties in that equipment."

CSEPP States may use more protective equipment. However, this is beyond the scope of CSEPP. CSEPP States that decide to use more protective equipment must assume certain responsibilities. These CSEPP States must:

- $\quad$ Provide own equipment;

- $\quad$ Comply with applicable regulations for such equipment;

- $\quad$ Perform required job duties; and

- Ensure that PPE has been tested against chemical warfare agents and appropriate for use with agents.

\section{Is Search and Rescue in an IDLH or Unknown Environment a Function of CSEPP?}

Search and rescue of survivors in an IDLH or unknown environment is beyond the scope of CSEPP. In this case, it would be the function of a HAZMAT team. Procedures for search and rescue should follow existing procedures established by local HAZMAT teams in their community. 
It is a CSEPP State's determination to pursue a search and rescue capability under these circumstances. However, CSEPP States should be prepared to assume all the responsibilities for this function.

\section{Does CSEPP Fulfill 1910.120 Requirements?}

According to 1910.120 (q) (4), skilled support personnel require instruction in:

- Wearing of appropriate PPE;

- What chemical hazards are involved; and

- What duties are to be performed.

There are no required minimum number hours of initial training and no mention of refresher training requirements.

CSEPP provides 24-32 training hours for participants. These training classes identify and describe the chemical hazards involved, what duties are to be performed, and the PPE to be worn. CSEPP meets, and actually exceeds the requirements according to 1910.120 (q).

\section{Where Can I Go for More Information?}

More detailed information can be obtained from sources such as those listed below.

CFR, Title 29, Part 1910.120. Hazardous Waste Operations and Emergency Response (HAZWOPER) Standard.

CFR, Title 29, HAZWOPER Standard, Appendix A - Personal Protective Equipment Test Methods.

CFR, Title 29, HAZWOPER Standard, Appendix B - General Description and Discussion of the Levels of Protection and Protective Gear.

CFR, Title 29, HAZWOPER Standard, Appendix C - Compliance Guidelines.

CFR, Title 29, Subpart I - Personal Protective Equipment, 1910.132 through 1910.138.

NFPA (National Fire Protection Association) 1991. Standard on Vapor-Protective Suits for Hazardous Chemical Emergencies.

NFPA (National Fire Protection Association) 1992. Standard on Liquid SplashProtective Suits for Hazardous Chemical Emergencies. 
NFPA (National Fire Protection Association) 1993. Standard on Liquid SplashProtective Suits for Non-emergency, Non-flammable Hazardous Chemical Situations.

NIOSH (National Institute for Occupational Safety and Health). Criteria for a Recommended Standard-Occupational Exposure to Hot Environments, Department of Health and Human Services, (NIOSH) Publication No. 86-113, April 1986.

Also included are World Wide Web homepage addresses for various regulatory and other accepted industry wide organizations.

\begin{tabular}{ll}
\hline Agency & WWW Address \\
\hline & \\
$\begin{array}{l}\text { Agency for Toxic Substances } \\
\text { and Disease Registry }\end{array}$ & \\
(ATSDR) & http://atsdr1.atsdr.cdc.gov:8080/atsdrhome.html \\
ACGIH & http://acgih.org/welcome.htm \\
AIHA & http://www.aiha.org/ \\
ANSI & http://www.ansi.org/ \\
Centers for Disease Control & \\
and Prevention (CDC) & http://www.cdc.gov/ \\
CFR & http://www.access.gpo.gov/nara/cfr-table-search.html \\
Environmental Protection & \\
Agency (EPA) & $h \mathrm{http://www.epa.gov/}$ \\
FEMA & $\mathrm{http://www.fema.gov/}$ \\
NFPA & $\mathrm{http://www.nfpa.org/}$ \\
NIOSH & $\mathrm{http://www.cdc.gov/niosh/homepage.html}$ \\
OSHA & $\mathrm{http://www.osha.gov/}$
\end{tabular}




\section{INFORMATION SHEET TO AID IN THE SELECTION OF THE APPROPRIATE LEVEL OF PERSONAL PROTECTIVE EQUIPMENT IN RESPONSE TO A CHEMICAL WARFARE AGENT ACCIDENT/INCIDENT}

Much of the information available today regarding chemical warfare agents has been obtained by the U.S. Army. The Army has worked with chemical warfare agents since before World War I. As a result, the Army has experience and knowledge regarding chemical agents. Knowledge that ranges from chemical and physical properties, mechanism of action, and physiological effects of the chemical agent to safety precautions and procedures for processing, handling, storage, transportation, disposal and decontamination of the agents. Much of the information that follows has been taken from the Army's AR 385-61 Chemical Agent Safety Program and the DA PAM 385-61 Toxic Chemical Agent Safety Standards.

\section{Who is the Intended Audience?}

The intended audience for this information sheet includes those individuals who may participate in the selection of the appropriate level of protection for personal protective equipment (PPE) in response to a chemical warfare agent accident/incident. This document can also be used by workers who need to increase their basic knowledge and understanding of the selection process. As this information sheet is intended as an overview of a complex subject, users are encouraged to consult the cited references for additional assistance.

\section{Chemical Warfare Agent Information Overview}

The information that follows has been taken from the Army's DA PAM 385-61 Toxic Chemical Agent Safety Standards. Chemical agents are not gases, although poison gas is a term commonly used for them. The first lethal chemical used in combat, in 1915, was chlorine gas, and "gas" became the common term. Most agents in the Army chemical munition stockpile are liquids, which were intended to be dispersed either as droplets or vapors.

Chemical agents produce various physiological effects on the human body. Chemical agents will produce a harmful physiological and/or psychological reaction when applied to the body externally, inhaled, ingested, or injected. Most chemical agents cause a disturbance of normal body functions. 
The two significant types of known modern chemical agents are blister agents and nerve agents. Blister (or vesicant) agents are persistent agents that act on the eyes, the lungs, and the skin, and burn and blister the skin or any other part of the body they contact. The common names of some blister agents are as follows:

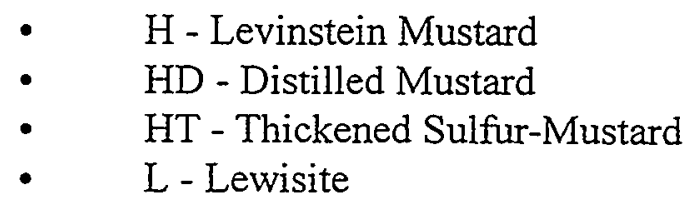

Nerve agents are organophosphorus compounds chemically related to pesticides, and include the $G$ and $V$ agents. The $G$ agents were developed in the 1930s and 1940s and are absorbed primarily through the respiratory system. The $\mathrm{G}$ agents can also be absorbed through the skin and eyes, particularly if they have been mixed with a thickener that slows evaporation, keeping them in liquid form for a longer time. The $\mathrm{V}$ agents, developed in the early 1950s, act by absorption through the skin. All nerve agents injure and kill by binding to cholinesterase, an enzyme in the human body that is essential for the functioning of the nervous system; they produce a range of neurological disorders followed by paralysis and cardiovascular or respiratory failure. The common names of some nerve agents are as follows:

$$
\begin{array}{ll}
\text { - } & \text { GA - Tabun } \\
\text { - } & \text { GB - Sarin - Soman } \\
\text { - } & \text { VX - (has no common name) }
\end{array}
$$

\section{Types of Hazards}

Hazards from mustard agents $(\mathrm{H}, \mathrm{HD}$ and $\mathrm{HT})$ are through vapor contact with the eyes, skin, or respiratory tract and liquid contact with skin. The most common acute hazard is that of liquid contact with the skin. Mustard is an insidious vesicant agent and has been identified as carcinogenic, teratogenic, and mutagenic.

The hazards from Lewisite (L) are similar to those of mustard agents. The most severe effect results from liquid contact with the eyes and skin. Lewisite is a vesicant agent and is considered a suspect carcinogen.

The hazard from $G$ agents (GA, GB, GD) is primarily that of vapor inhalation through the respiratory tract, although the agents may be absorbed through the eyes or skin. $G$ agents are highly toxic and quick acting. GB is nonpersistent when disseminated as a cloud of very fine particles or as a vapor. 
The hazard from VX is primarily that of liquid absorption through the skin, although it may be readily absorbed as an aerosol through the respiratory tract and eyes and ingested through the gastrointestinal tract. VX is slow to evaporate and may persist as a liquid for several days (i.e., VX is persistent).

VX is an anticholinesterase compound similar to GB in mechanism of action and effects. Because VX has a low volatility, liquid droplets on the skin do not evaporate quickly, thereby facilitating effective percutaneous absorption. By this route, $\mathrm{VX}$ is approximately 10 times as toxic as GB in humans. By the inhalation route, VX is estimated to be twice as toxic as GB.

\section{Key Criteria for Consideration in the Selection of Appropriate PPE}

According to 29 Code of Federal Regulations (CFR) 1910.132 General Requirements:

PPE. . shall be provided, used, and maintained. . . wherever it is necessary by reason of hazards of processes or environment, chemical hazards, radiological hazards, or mechanical irritants encountered in a manner capable of causing injury or impairment in the function of any part of the body through absorption, inhalation or physical contact.

The Occupational Safety and Health Administration (OSHA) has not promulgated a federal regulation regarding testing procedures for protective clothing. Absent such federal regulation, industry has adopted voluntary industry-wide consensus standards (i.e., procedures/protocols agreed upon and upheld by industry) for protective clothing. There are several well respected organizations that have developed testing procedures/protocols. Some of these organization include the National Fire Protection Association (NFPA), the American Society for Testing and Materials (ASTM), and the American National Standards Institute (ANSI). When handling chemical warfare agents, the U.S. Army, in particular, has developed testing procedures/protocols that it would be prudent to follow.

Selection of the appropriate PPE is a complex process which should take into consideration a variety of factors. Key factors involved in this process are:

- identification of the hazards, or suspected hazards,

- their routes of potential hazard to employees (i.e., inhalation, skin absorption, ingestion, and eye or skin contact), and

- $\quad$ the performance of the PPE materials (and seams) in providing a barrier to these hazards. 
Other factors to be considered in this selection process are matching the PPE to the employee's work requirements and task-specific conditions. The durability of PPE . materials, such as tear strength and seam strength, should be considered in relation to the employee's tasks. The effects of PPE in relation to heat stress and task duration are also factors in selecting and using PPE. In some cases, layers of PPE may be necessary to provide sufficient protection, or to protect expensive PPE inner garments, suits or equipment.

The amount of protection provided by PPE is material-hazard specific. That is, a given protective equipment material may protect well against some hazardous substances and poorly, or not at all, against others. In many instances, protective equipment materials cannot be found which will provide continuous protection from particular hazardous substances. In these cases, the breakthrough time of the protective material should not exceed the work durations.

Occupational Safety And Health Administration's (OSHA) Criteria for the Selection of the Appropriate Level of PPE Protection

OSHA has outlined the appropriate level of protection for situations involving hazardous materials in 29 CFR 1910.120 Hazardous Waste Operations and Emergency Response (HAZWOPER), Appendix B: General Description and Discussion of the Levels of Protection and Protective Gear. According to OSHA:

\section{OSHA Level A}

Level A protection should be used when:

- The hazardous substance has been identified and requires the highest level of protection for skin, eyes, and the respiratory system based on either the measured (or potential for) high concentration of atmospheric vapors, gases, or particulates; or the work involves a high potential for splash, immersion, or exposure to unexpected vapors, gases, or particulates of materials that are harmful to skin or capable of being absorbed through the skin.

- Substances with a high degree of hazard to the skin are known or suspected to be present, and skin contact is possible; or

- Operations are being conducted in confined, poorly ventilated areas, and the absence of conditions requiring Level $\mathrm{A}$ have not yet been determined. 
The following equipment collectively constitute Level A protection.

- $\quad$ Positive pressure, full face-piece self-contained breathing apparatus (SCBA), or positive pressure, supplied air respirator with escape SCBA, approved by the National Institute for Occupational Safety and Health (NIOSH).

- Totally-encapsulating chemical-protective suit.

- Coveralls (optional, as applicable).

- Long underwear (optional, as applicable).

- Gloves, outer, chemical-resistant.

- Gloves, inner, chemical-resistant.

- Boots, chemical-resistant, steel toe and shank.

- Hard hat under suit (optional, as applicable).

- Disposable protective suit, gloves and boots (depending on suit construction, may be worn over totally-encapsulating suit).

\section{OSHA Level B}

Level B protection should be used when:

- The type and atmospheric concentration of substances have been identified and require a high level of respiratory protection but less skin protection; or

- The atmosphere contains less than 19.5 percent oxygen; or

- The presence of incompletely identified vapors or gases is indicated by a directreading organic vapor detection instrument, but vapors and gases are not suspected of containing high levels of chemicals harmful to skin or capable of being absorbed through the skin.

NOTE: Level B protection can be used in atmospheres with immediately dangerous to life and health (IDLH) concentrations of specific substances that (1) present severe inhalation hazards but do not represent a severe skin hazard or (2) do not meet the criteria for use of air-purifying respirators.

The following equipment collectively constitute Level B protection. (Any difference from Level $\mathrm{A}$ is bolded.)

- $\quad$ Positive pressure, full face-piece SCBA, or positive pressure, supplied air respirator with escape SCBA (NIOSH approved).

- Hooded chemical-resistant clothing (e.g., overalls and long-sleeved jacket, coveralls, one or two-piece chemical-splash suit, disposable chemicalresistant overalls).

- $\quad$ Coveralls (optional, as applicable).

- Gloves, outer, chemical-resistant.

- Gloves, inner, chemical-resistant.

- Boots, outer, chemical-resistant, steel toe and shank. 
- Boot-covers, outer, chemical-resistant (disposable, optional, as applicable).

- Hard hat (optional, as applicable).

- $\quad$ Face shield (optional, as applicable).

\section{OSHA Level C}

Level C protection should be used when:

- The atmospheric contaminants, liquid splashes, or other direct contact will not adversely affect or be absorbed through any exposed skin, or

- The types of air contaminants have been identified, concentrations measured, and an air-purifying respirator is available that can remove the contaminants, and

- All criteria for the use of air-purifying respirators are met.

The following equipment collectively constitute Level $\mathrm{C}$ protection. (Any difference from Level B is bolded.)

- $\quad$ Full-face or half-mask, air purifying respirators (NIOSH approved).

- Hooded chemical-resistant clothing (e.g., overalls, two-piece chemical-splash suit, disposable chemical-resistant overalls).

- Coveralls (optional, as applicable).

- Gloves, outer, chemical-resistant.

- Gloves, inner, chemical-resistant.

- Boots, outer, chemical-resistant, steel toe and shank (optional, as applicable).

- Boot-covers, outer, chemical-resistant (disposable, optional, as applicable).

- Hard hat (optional, as applicable).

- $\quad$ Escape mask (optional, as applicable).

- Face shield (optional, as applicable).

\section{OSHA Level D}

Level $\mathrm{D}$ protection should be used when:

- the atmosphere contains no known hazard, and

- work functions preclude splashes, immersion, or the potential for unexpected inhalation of or contact with hazardous levels of any chemicals.

The following equipment collectively constitute Level D protection. (Any difference from Level $\mathrm{C}$ is bolded.)

- Coveralls.

- $\quad$ Gloves (optional, as applicable).

- Boots/shoes, chemical-resistant, steel toe and shank. 
- Boots, outer, chemical-resistant (disposable, optional, as applicable).

- Safety glasses or chemical splash goggles.

Appropriate Level of Protection for Individuals Performing Decontamination

According to OSHA's Inspection Procedures Manual for the HAZWOPER Standard, 29 CFR 1910.120(q), individuals performing decontamination should wear PPE at the same level or one below the emergency responders they are supporting.

\section{U.S. Army's Criteria for the Selection of the Appropriate Level of PPE Protection in Response to a Chemical Warfare Agent Accident/Incident}

The Army's definitions and selection criteria differ from those used by OSHA. OSHA's definitions and selection criteria are for hazardous materials in general, while the Army's are specific to toxic chemical agents. The following information is provided to clarify those differences, thereby helping to avoid confusion that might otherwise occur. There are several different military suit configurations for each level of protection. The description below specifies the level, the military suit, and under what conditions the suit should be worn. The information that follows describes only military suit configurations. The acronyms that follow (e.g., M3, M40, M2A1) are military names for various pieces of protective equipment. There are other pieces of commercial protective clothing not identified in this information sheet that would be appropriate for use with chemical agents. This information sheet is not meant to be an all inclusive list identifying all the protective clothing that can be used with chemical agents. This information sheet should be used to help identify the information necessary to make decisions regarding the selection of the appropriate level of PPE for use with chemical agents. For more detailed information, please refer to the Army's AR 385-61 Chemical Agent Safety Program, and the DA PAM 385-61 Toxic Chemical Agent Safety Standards. The information that follows has been taken from the Army's DA PAM 385-61 Toxic Chemical Agent Safety Standards.

NOTE: Not all Army respiratory equipment has been NIOSH approved. This equipment would be appropriate for the military to use, however, it would not be appropriate for civilian use. All civilian respiratory equipment must be NIOSH approved.

\section{Army Level A}

Level A protection will be worn:

- in areas below IDLH environments; and/or

- at or above $0.003 \mathrm{mg} / \mathrm{m}^{3}$ for mustard and lewisite environments when liquid agent is present. 
For these situations, the cuffs of the sleeves and legs of the M3 toxicological agent protective (TAP) suit may be taped to the gloves and boots to reduce the amount of outside air drawn into the suit.

The M3 TAP ensemble described below constitutes Level A equipment. This ensemble is made of butyl rubber and is not a positive pressure system, thus some outside air will enter the suit through the sleeves, neck, and leg openings if not taped. The M3 TAP suit is approved for use with $\mathrm{G}$ series, VX, and $\mathrm{H}$ series agents.

- $\quad$ M3 TAP suit - coveralls.

- $\quad$ Hood - TAP (M3, M40 SP).

- Boots - butyl, safety toe, TAP (M2A1).

- $\quad$ Gloves - butyl, TAP (M3, M4, gloveset).

- $\quad G B / V X$ - surgical or other equivalent nonstandard gloves will be worn underneath for protection when doffing TAP clothing.

- Mustard - surgical or other equivalent nonstandard gloves are optional.

- Innerwear

- $\quad \mathrm{GB} / \mathrm{VX}$ - coveralls, fatigues, or equivalent government issued clothing (with drawers and undershirt) and socks. Alternative - long underwear and socks.

- $\quad$ Mustard and Lewisite - impregnated gloves, impregnated socks, and impregnated long underwear or impregnated protective liner to include shirt and trousers or the chemical protective undergarment (CPU) with socks and gloves. Coveralls, fatigues, equivalent government issued clothing or unimpregnated underwear may be worn in addition.

NOTE: Surgical gloves will not be worn in operations involving M55 rockets outside their shipping and firing tubes, or in operations where exposed explosives or propellants are present or where a hazard analysis indicates electrostatic initiation is possible.

- $\quad$ Mask (respirator) - worn (M9 and M40 series).

\section{Army Alternate Level A}

Alternate Level A protection will be worn:

- in IDLH and $/ a t 0.00^{3} \mathrm{mg} / \mathrm{m} 3$ for mustard and lewisite, or

- in proximity to spilled agent in an area of known liquid contamination, or

- whenever Real Time Monitoring with Alarm capability is not available.

There are several different approved Alternate Level A ensembles. They are as follows: 
The demilitarization protective ensemble (DPE). The DPE (20- and 30 mil) is a totally encapsulating, chemical protective suit which operates at a positive pressure to assure total protection against inward leaks. The DPE is an air supplied ensemble with a 10minute emergency internal breathing system. The DPE is approved for use with $G$ series, VX, $\mathrm{L}$, and $\mathrm{H}$ series agents. DPE is a one-time use only suit.

The toxicological agent protective ensemble self-contained 1-hour (TAPES). The TAPES is a totally encapsulating, positive pressure air pack suit with an integrated cooling system designed for a 1-hour mission in IDLH and/or $0.003 \mathrm{mg} / \mathrm{m}^{3}$ for mustard and lewisite environments. TAPES is approved for use with G series, VX, L, and $H$ series agents. Wear of the 20-mil TAPES in mustard environment is limited to 1 hour at 80 degrees $\mathrm{F}$ or less and no more than 45 minutes in temperatures between 80 and 90 degrees $\mathrm{F}$. The 20-mil TAPES is not authorized for use in mustard environments at temperatures exceeding 90 degrees $\mathrm{F}$.

The M3 suit with M30 hood and SCBA pressure demand, Modified Level A. This ensemble is not a positive pressure system. The modified M3 TAP utilizes a pressure demand SCBA and full-face respirator in a modified M30 hood and is authorized for use in IDLH and $/$ or $0.003 \mathrm{mg} / \mathrm{m}^{3}$ for mustard and lewisite environments. The cuffs of the sleeves and legs will be taped to the gloves and boots to reduce the amount of outside air drawn into the suit.

The self-contained toxicological environmental protective outfit-interim (STEPO-I). The STEPO-I is a personnel protective system for use in IDLH and $/$ or $0.003 \mathrm{mg} / \mathrm{m}^{3}$ for mustard and lewisite environments. It provides total encapsulation for the user. The suit is provided with an air-line tether or self-contained air supply. The STEPO-I suit is made from the same butyl rubber material as the M3 TAP ensemble. The STEPO-I is approved for use with $\mathrm{G}$ series, $\mathrm{VX}$, and $\mathrm{H}$ series agents.

Air supplied or self-contained respiratory protection is required when airborne agent concentrations exceed the IDLH and/or $0.003 \mathrm{mg} / \mathrm{m}^{3}$ for mustard and lewisite environments, or when in areas of potential but unknown airborne contamination.

\section{Army Level B}

Level B equipment will be worn when:

- contact with suspect items is required, or

- $\quad$ when performing operations that may result in the release of agent vapors (e.g., air sampling inspection of stocks or inspection/repair of equipment, but no contact with liquid agent is anticipated and no liquid agent is present). 
The following equipment collectively constitutes Level B protection.

- $\quad$ Apron - TAP (M2); extending below top of boots.

- Innerwear.

- GB/VX - coveralls, fatigues, or equivalent government issued clothing (with drawers and undershirt) and socks.

- Mustard - impregnated gloves; impregnated socks; and impregnated protective liner to include shirt and trousers or the CPU with socks and gloves.

Coveralls, fatigues, equivalent government issued clothing, or unimpregnated underwear may be worn in addition.

- Hood - TAP (M3 for M9 mask, M3A1 for M40 mask or M6A2 for M17 mask).

- Boots - butyl, safety toe, TAP (M2A1).

- $\quad$ Gloves - butyl, TAP (M3, M4, gloveset).

- GB/VX - surgical or other equivalent nonstandard gloves will be worn underneath for protection when doffing TAP clothing.

- Mustard - surgical or other equivalent nonstandard gloves optional. NOTE Surgical gloves will not be worn in operations involving M55 rockets outside their shipping and firing tubes, or in operations where exposed explosives or propellants are present or where a hazard analysis indicates electrostatic initiation is possible.

- Mask (respirator) - worn (M9-, M17- or M40-series).

The ensemble described above is approved for use with $\mathrm{G}$ series, VX, $\mathrm{L}$, and $\mathrm{H}$ series agents.

\section{Army Level C}

Level $\mathrm{C}$ equipment will be worn:

- by personnel who must be in agent areas where handling or contact with agentfilled items is involved; or

- if real time monitoring to IDLH and/or $0.003 \mathrm{mg} / \mathrm{m}^{3}$ for mustard and lewisite level is being performed.

The following equipment collectively constitutes Level C protection.

- $\quad$ Boots - butyl, safety toe, TAP (M2A1).

- $\quad$ Gloves - butyl, (M3, M4, gloveset).

- Apron - TAP (M2), extending below top of boots. Required only if hazard analysis determines that bodily contact with agent-filled items may occur. 
- Clothing - unimpregnated - coveralls or fatigues - or equivalent government issued clothing, socks, drawers, undershirt.

- $\quad$ Mask (respirator) - worn (M9-, M17-, or M40-series).

The ensemble described above is approved for use with $G$ series, VX, $L$, and $H$ series agents.

\section{Army Level D}

Level $\mathrm{D}$ equipment will be worn:

- by personnel in clean areas where handling or contact with agent-filled items is involved provided that real time low level monitoring with alarm is being performed at or below the with negative results.

- if monitoring to determine the airborne exposure limits (AELs) is being performed confirming negative results.

The following equipment collectively constitutes Level $\mathrm{D}$ protection.

- $\quad$ Boots - butyl, safety toe, TAP (M2A1).

- $\quad$ Gloves - butyl, (M3, M4, gloveset).

- $\quad$ Apron - TAP (M2); extending below top of boots. Required only if hazard analysis determines that bodily contact with agent-filled items may occur.

- Clothing - unimpregnated - coveralls, or fatigues - or equivalent government issued clothing, socks, drawers, undershirt.

- $\quad$ Mask - slung position (M9-, M17- or M40-series).

The ensemble described above is approved for use with $\mathrm{G}$ series, VX, $\mathrm{L}$, and $\mathrm{H}$ series agents.

\section{Army Level E}

Level $E$ equipment should be worn:

- by operating personnel who may be observing or supervising chemical agent operations, or

- by personnel who would not likely contact an item or would only be exposed to agent in the event of a chemical agent accident. 
The following equipment collectively constitutes Level E protection.

- Clothing - unimpregnated - coveralls or fatigues - or equivalent government issued clothing, socks, drawers, undershirt.

- $\quad$ Mask - slung position (M9-, M17- or M40-series). For laboratories, the mask may be readily available at the work site instead of in a slung position.

- In laboratories, a lab coat may be substituted for coveralls, fatigues, or equivalent.

- $\quad$ Gloves, butyl (M3, M4, or gloveset).

- Safety shoes - if job hazard analysis determines the necessity.

The ensemble described above is approved for use with G series, VX, $\mathrm{L}$, and $\mathrm{H}$ series agents.

\section{Army Level F}

Level $\mathrm{F}$ is limited to casual or transient personnel who may be required to visit clean storage or operating areas.

The following equipment collectively constitutes Level $\mathrm{F}$ protection.

- $\quad$ Clothing - street clothing.

- $\quad$ Mask - slung position (M9-, M17- or M40-series).

The ensemble described above is approved for use with $\mathrm{G}$ series, VX, $\mathrm{L}$, and $\mathrm{H}$ series agents.

\section{Emergency Response Personnel}

Trained emergency response personnel responding to an accident or emergency situation should wear the level of protection that is indicated by the conditions that exist. When emergency conditions involve exposure to potential liquid agent, the Army specifies that Alternate Level A protection will be worn. However, where exposure to only agent vapor is involved, the Army indicates that Level B protection may be worn when agent concentrations do not exceed IDLH and/or $0.003 \mathrm{mg} / \mathrm{m}^{3}$ for mustard and lewisite levels.

\section{Where Can I Go for More Information?}

More detailed information to aid in the selection of PPE can be obtained from sources such as those listed below. ANSI (American National Standards Institute), American National Standard for
Respiratory Protection, ANSI Z88.2-1992, New York. 
CFR, Title 29, Part 1910.120 Hazardous Waste Operations and Emergency Response (HAZWOPER) Standard.

CFR, Title 29, Part 1910.134, Respiratory Protection.

Department of the Army, Chemical Agent Safety Program, AR 385-61, Office of the Chief of Staff, Washington, D.C., February 1997.

Department of the Army, Toxic Chemical Agent Safety Standards, DA PAM 385-61, Office of the Chief of Staff, Washington, D.C., March 1997.

Also included are World Wide Web homepage addresses for various regulatory and other accepted industry wide organizations.

\begin{tabular}{|c|c|}
\hline Agency & Address \\
\hline \multicolumn{2}{|l|}{$\begin{array}{l}\text { Agency for Toxic Substances } \\
\text { and Disease Registry }\end{array}$} \\
\hline (ATSDR) & http://atsdr1.atsdr.cdc.gov:8080/atsdrhome.html \\
\hline ACGIH & http://acgih.org/ \\
\hline AIHA & http://www.aiha.org/ \\
\hline ANSI & http://www.ansi.org/ \\
\hline $\begin{array}{l}\text { Centers for Disease Control } \\
\text { and Prevention (CDC) }\end{array}$ & http://www.cdc.gov/ \\
\hline CFR & http://www.access.gpo.gov/nara/cfr-table-search.html \\
\hline \multicolumn{2}{|l|}{ Environmental Protection } \\
\hline Agency (EPA) & http://www.epa.gov/ \\
\hline FEMA & http://www.fema.gov/ \\
\hline NFPA & http://www.nfpa.org/ \\
\hline NIOSH & http://www.cdc.gov/niosh/homepage.html \\
\hline OSHA & http://www.osha.gov/ \\
\hline \multicolumn{2}{|l|}{ U.S. Army Edgewood Research } \\
\hline $\begin{array}{l}\text { Development and Engineering } \\
\text { Center (ERDEC) }\end{array}$ & $\begin{array}{l}\text { http://www.cbdcom.apgea.army.mil/RDA/erdec/risk/ } \\
\text { safety/index.html }\end{array}$ \\
\hline $\begin{array}{l}\text { Medical NBC Online } \\
\text { Information Server }\end{array}$ & http://www.nbc-med.org/others/index.html \\
\hline NBC Industry Group & http://www.nbcindustrygroup.com/index.html \\
\hline
\end{tabular}




\section{INFORMATION SHEET ON RESPIRATOR FLTERS, CARTRIDGES, AND CANISTERS}

\section{Who is the Intended Audience?}

The intended audience for this information sheet are those individuals who may participate in the selection of appropriate respirator filters, cartridges, and canisters, and workers who need to increase their basic knowledge and understanding of filters, cartridges, and canisters. As this information sheet is intended as an overview of a complex subject, users are encouraged to consult the references cited herein for additional assistance.

\section{What Does the Selection Process Involve?}

The selection process for the proper filter, cartridge or canister should begin after the appropriate respirator has been identified. The thought process should include the same type considerations given to the selection of the best respirator for the job including:

- the nature of the hazardous operation or process,

- the type of respiratory hazard (including physical properties, chemical properties, warning properties, effects on the body, concentration of toxic material or airbome radioactivity level, established permissible time weighted-average concentration for toxic material or established maximum permissible airborne concentration for radioactive material, and concentrations immediately dangerous to life and health $\{\mathrm{IDLH}\}$ for toxic material),

- the location of the hazardous area in relation to the nearest area having respirable air,

- the period of time for which respiratory protection must be provided,

- the activities of workers in the hazardous areas,

- the functional and physical characteristics of the various types of respirators, and

- the respirator protection factors and respirator fit.

Chemical cartridges and canisters are used to remove specific gases and vapors; mechanical filters are used to remove particulate matter. Contact the manufacturer of your respirator for help in selecting the appropriate filter, cartridge or canister for the type of respiratory hazard expected to be encountered.

1. The standard for filters, cartridges and canisters is contained in 42 Code of Federal Regulations (CFR) 84, Respiratory Protective Devices. According to 42 CFR 84, all filters, cartridges and canisters must be tested and approved by the National Institute of Occupational Safety and Health (NIOSH). Ask the manufacturer for the NIOSH approval number. 


\section{How Do Filters Work?}

Filters offer respiratory protection against airborne particulate matter, including dusts, mists, metal fumes, and smokes. Directly attached to the facepiece is one of several types of filters made up of a fibrous material that removes the harmful particles by trapping them as air is inhaled through the material. The filter must be highly efficient, however, to trap the smaller particles. There are many types of filters specifically designed for the various classes of airborne particulate matter.

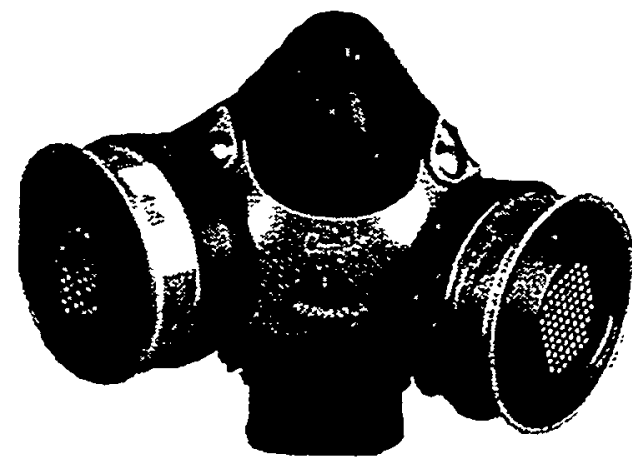

\section{What Are Their Limitations?}

Filters do not provide protection against gases, vapors, or oxygen deficiency. Use of filters is limited to those environments where there is sufficient oxygen to sustain life and the air-contaminant level is within the specified concentration limitation of the device. The useful life of a filter is limited by the concentration of the air contaminants, the breathing demand of the wearer, and the removal capacity of the filter.

\section{How Do Chemical Cartridges and Canisters Work?}

Cartridges and canisters normally remove the contaminant by interaction between the contaminant and the sorbent. The sorbent consists of a granular, porous material. The general method of removal is called sorption. Sorption is the process of being taken up or held by either absorption or adsorption. Absorption is the process of absorbing or of being absorbed (to take in and make part of an existent whole). Adsorption is the condensation of gases, liquids, or dissolved substances on the surfaces of solids. In addition to sorption, some cartridges/canisters use an agent which react with the contaminant

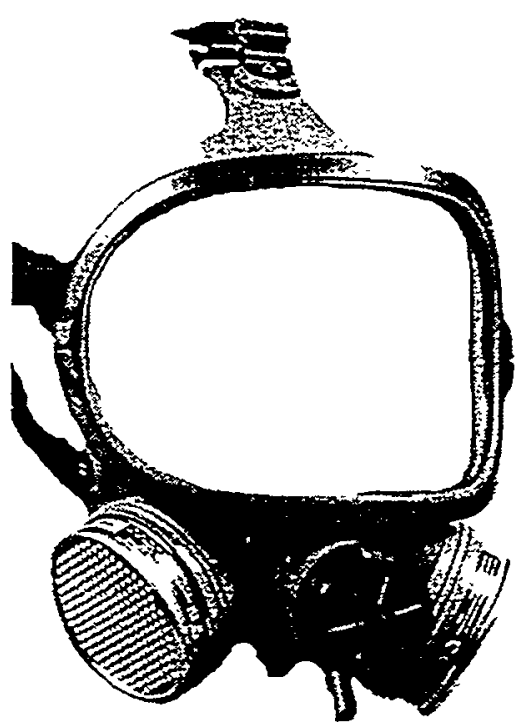
to produce a less toxic gas or vapor. 
The basic difference between cartridges and canisters is the volume of sorbent contained, not function. Cartridges may be used singly or in pairs on quarter- and half-masks and on full-facepieces. The sorbent volume of a cartridge is small, so the useful lifetime is usually short, particularly in high gas or vapor concentrations. Therefore, use of respirators with cartridges generally is restricted to low concentrations of vapors and gases.

Canisters have a larger sorbent volume and may be chin-, front-, or back-mounted. Respirators with canisters can be used in higher vapor and gas concentrations (up to IDLH concentrations) than those with cartridges. Canisters differ from cartridges only in their larger sorbent volume and the higher concentrations of vapors and gases against which they provide protection.

There are combination filter/cartridge respirators. These use dust, mist, or fume filters with a cartridge for dual or multiple exposure. Respirators with independently replaceable filters are sometimes used because the filter normally plugs (or clogs up) before the cartridge is exhausted. The filter is easily replaced and extends the life of the respirator.

\section{What Are Their Limitations?}

Cartridges and canisters are nonemergency protective devices and should never be used in IDLH atmospheres. Cartridges and canisters should only be used in atmospheres which contain sufficient oxygen to support life.

Rules for cartridge use are as follows:

- Do not use cartridges for exposures to harmful gases and vapors unless the employer implements a change schedule that is based on objective information or data that will ensure that cartridges are

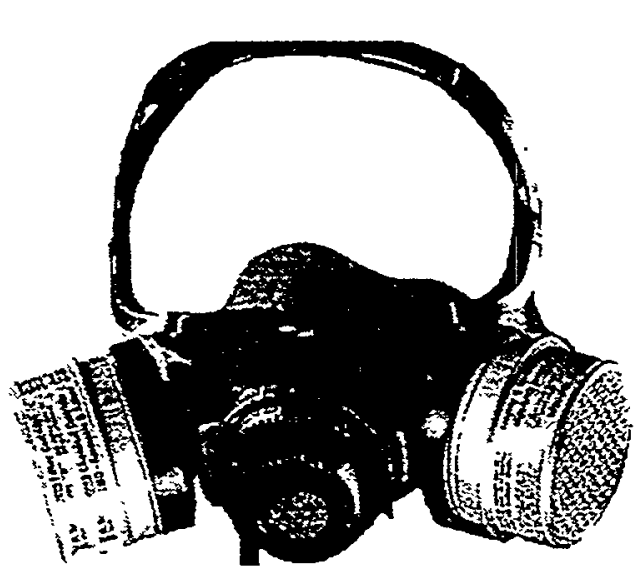
changed before the end of their service life.

- Satisfactory eye protection must be used, along with cartridges, for any gaseous material in concentrations that are highly irritating to the eye. 
- Cartridges cannot be used for protection against gaseous material that is not effectively stopped by a cartridge's chemical fill, regardless of concentrations.

Canisters should be replaced under any one or more of the following conditions:

- If canisters with window indicators show specified color changes.

- If leakage is detected by smell, taste, or eye, nose, or throat irritation.

- If high resistance to breathing develops.

- If the canister shelf life is exceeded.

- If uncomfortable heat is present in inhaled air.

- If the wearer has a feeling of nausea, dizziness, or ill-being.

\section{Which Cartridge is Right for the Chemical Stockpile Emergency Preparedness Program (CSEPP)?}

The combination organic vapor/ high efficiency particulate air (OV/HEPA) cartridge is the only cartridge approved for use in CSEPP.

The cartridges from four commercial air-purifying respirators were tested by Battelle and approved by the Centers for Disease Control and Prevention's National Center for Environmental Health (CDC/NCEH). NIOSH confirmed the tests on the cartridges were conducted in a valid, scientific manner consistent with the Certification and Quality Assurance Branch of NIOSH certification test protocols and 42 CFR 84 requirements for chemical cartridges or filters. The data in the report support the conclusion that the commercial cartridges tested will remove up to 0.5 milligrams per cubic meter of nerve agent GB for up to 16 hours. This concentration was chosen because it is the maximum predicted concentration to which a worker would be exposed. The duration of 16 hours is the longest that any worker would be expected to wear a respirator (12 hours is the expected duration). Data provided by the U.S. Army on the military-gas mask indicate sorbents have the shortest service life against nerve agent GB than any other lethal chemical agents.

\section{What Do They Cost?}

Individual filters, cartridges and canisters may range in price from $\$ 10-\$ 100$. Filters, cartridges, and canisters should be purchased through the same vendor who supplied the respirators. 


\section{Where Can I Go for More Information?}

More detailed information can be obtained from sources such as those listed below. Minimum respiratory protection requirements for contaminants can be found in the following references, or in separate sections for specific contaminants (e.g., 1910.1001 for asbestos, 1910.1025 for lead, etc.).

ANSI (American National Standards Institute), American National Standard for Respiratory Protection, ANSI Z88.2-1992.

CFR, Title 42, Part 84, Respiratory Protective Devices.

CFR, Title 29, Part 1910.134, Respiratory Protection.

CFR, Title 29, Part 1910.120 Hazardous Waste Operations and Emergency Response (HAZWOPER).

NFPA (National Fire Protection Association), Hazardous Materials Response Handbook, (Contains NFPA 471, 472, and 473), Second Edition, Gary Tokle Editor, 1992.

NIOSH (National Institute for Occupational Safety and Health), A Guide to Industrial Respiratory Protection. Cincinnati: U.S. Department of Health, Education, and Welfare, Public Health Service, Centers for Disease Control, 1976, NIOSH publication 76-189.

National Safety Council, Fundamentals of Industrial Hygiene, Third Edition, Barbara Plog, Editor, 1988.

Also included are World Wide Web homepage addresses for various regulatory and other accepted industry wide organizations.

\begin{tabular}{ll}
\hline Agency & WWW Address \\
\hline $\begin{array}{l}\text { Agency for Toxic Substances } \\
\text { and Disease Registry }\end{array}$ & \\
$\quad$ (ATSDR) & http://atsdr1.atsdr.cdc.gov:8080/atsdrhome.html \\
American Conference of & \\
$\begin{array}{l}\text { Governmental Industrial } \\
\text { Hygienists (ACGIH) }\end{array}$ & http://acgih.org/welcome.htm \\
American Industrial Hygiene & http://www.aiha.org/ \\
Association (AIHA) & http://www.ansi.org/ \\
ANSI & http://www.cdc.gov/ \\
Centers for Disease Control (CDC) & $6-5$
\end{tabular}


CFR

Environmental Protection

Agency (EPA)

FEMA

NFPA

NIOSH

Occupational Safety and Health

Administration (OSHA)

3M Racal Health and Safety

Mine Safety Appliances

Survivair http://www.access.gpo.gov/nara/cfr-table-search.html

http://www.epa.gov/

http://www.fema.gov/

http://www.nfpa.org/

http://www.cdc.gov/niosh/homepage.html

http://www.osha.gov/

http:/www.racalhealth.com/index.htm

http:/www.msanet.com/

http://biminic.com/surviv1.htm 


\title{
7. INFORMATION SHEET TO AID IN THE SELECTION OF APPROPRIATE RESPIRATORY PROTECTION
}

\author{
Who is the Intended Audience?
}

The intended audience for this information sheet are those individuals who may participate in the selection of appropriate respiratory equipment, or for the worker who wants to increase his/her basic knowledge and understanding of the selection process. As this information sheet is intended as an overview of a complex subject, users are encouraged to consult the references cited herein for additional assistance.

\section{What Does the Selection Process Involve?}

According to the Occupational Safety and Health Administration (OSHA), the standard developed for respiratory protection is 29 Code of Federal Regulations (CFR) 1910.134 Respiratory Protection. This standard states respirators shall only be used when engineering controls are not feasible or effective, while controls are being installed or repaired, or for emergency and other temporary (intermittent) situations. Respirator selection is very complex and should be performed by an Industrial Hygienist or other professional knowledgeable in respiratory protective devices.

Minimum respiratory protection requirements for all contaminants can be found in OSHA standards 29 CFR 1910.134 Respiratory Protection, 29 CFR 1910.120 Hazardous Waste Operations and Emergency Response (HAZWOPER), or in separate sections for specific contaminants (e.g., 1910.1001 for asbestos, 1910.1025 for lead, etc.).

Much of the information that follows is taken from 29 CFR 1910.134 Respiratory Protection, and from the National Institute of Occupational Safety and Health's (NIOSH) NIOSH Guide to Industrial Respiratory Protection.

\section{Responsibilities}

According to 29 CFR 1910.134, respirators must be provided by the employer when such equipment is necessary to protect the employee.

- The employer must provide respirators that are applicable and suitable for the purpose intended.

- The employer must also be responsible for the establishment and maintenance of a respiratory protection program in accordance with 29 CFR 1910.134 (and any other relevant federal regulations). 
On the other hand, the employee has responsibilities to the employer, fellow employees, and self.

- The employee must use the provided respiratory protection in accordance with instructions and training received.

- The employee must guard against damage to the respirator.

- If a malfunction occurs, the employee must immediately leave the area and report the malfunction to a responsible person.

- Lastly, the employee must report any change in his/her medical status that may impact the employee's ability to wear a respirator safely.

\section{Requirements for a Minimal Acceptable Respiratory Protection Program}

The employer is required to develop and implement a written respirator protection program with required worksite-specific procedures and elements for required respirator use. The program must be administered by a suitably trained program administrator. OSHA released a guide that contains criteria for the selection of a program administrator and a sample program that meets OSHA requirements. The Small Entity Compliance Guide is available at the OSHA Office of Publications, (202) 219-4667.

\section{A. Respiratory Program Administrator}

Providing suitable respirators to workers may seem simple, but issuance of an unsuitable respirator may result in worker injury or death, so the matter cannot be treated lightly. The person (i.e., the Respiratory Program Administrator) responsible for issuing respirators must be adequately trained or have appropriate experience to make sure that the correct respirator is provided for each job.

\section{B. Written Standard Operating Procedures}

Written standard operating procedures covering the complete respirator program shall be established and implemented. Generally, the procedures should contain the following:

- Guidance for selection of respirators for protection against the particular hazard.

- Detailed instructions for training workers in the proper use of respirators, including respirator fitting.

- Detailed maintenance procedures for:

- cleaning and disinfection,

- drying,

- inspection,

- repair or replacement or worn or defective components, and

- storage. 
- Administrative procedures for:

- purchase of approved respirators,

- control of inventory of spare parts, new respirators, and respirators ready for reissue after maintenance,

- issuance of respirators to ensure use of the proper one for a given hazard, and

- guidance of supervisory personnel in continued surveillance of respirator use and determination of workers' exposure to respiratory hazards.

- Instructions for respirator use during emergencies, including fire.

- Guidelines for medical surveillance of workers, including pre-employment physical examinations to eliminate those physically or psychologically unfit to wear respirators, and periodic physical examinations to review the overall effectiveness of the respirator program on basis of physiological factors.

- Procedures for evaluating the respirator program's effectiveness.

\section{Medical Surveillance}

According to 29 CFR 1910.134, no one should be assigned a task requiring the use of respirators unless found physically able to do the work while wearing the respirator. A physician or other licensed health care professional should perform a medical evaluation using a medical questionnaire (i.e., 1910.134 Appendix C OSHA Respirator Medical Evaluation Questionnaire) or an initial medical examination that obtains the same information as the medical questionnaire in Appendix C. Each respirator wearers' medical status should be reviewed periodically (e.g., annually).

In addition, some regulatory standards for specific substances and occupations may also contain requirements for medical examinations. For example, members of an organized and designated HAZMAT team shall receive a baseline physical examination and be provided with medical surveillance as outlined in paragraph (f) of 29 CFR 1910.120.

NOTE: Emergency response workers involved with the Chemical Stockpile Emergency Preparedness Program (CSEPP) are required to follow the medical requirements as specified in 29 CFR 1910.134 .

\section{Training}

The content of the training program can vary widely, depending on the circumstances. However, 29 CFR 1910.134 requires training of both workers and supervisors and must include the following:

- an opportunity to handle the respirator,

- proper fitting, 
- test of facepiece-to-face seal, and

- a familiarizing period of wear in normal air.

The wearer should receive fitting instructions including demonstrations and practice in wearing, adjusting, and determining the fit of the respirator. Training of supervisors and workers must also include the following:

- the respiratory hazard and the effect on the wearer if the respirator is not used properly,

- the engineering and administrative conditions being used and the need for respirators to provide protection,

- the reason for selecting a particular type of respirator,

- the function, capabilities, and limitations of the selected respirator,

- how to recognize medical signs and symptoms that may limit or prevent the effective use of respirators,

- the method of donning the respirator and checking its fit and operation,

- the proper wearing of the respirator,

- respirator maintenance, inspection, and storage,

- recognizing and handling emergency situations, and

- applicable governmental regulations for specific substances.

Retraining shall be conducted annually, and/or when any situation arises that could potentially impact safe respirator use.

\section{E. Fitting}

All the care that goes into the design, manufacture and certification of a tight-fitting respirator to ensure its maximum efficiency will not protect the wearer if there is an improper match between facepiece and wearer or improper wearing practices. Determination of facepiece fit involves both qualitative and quantitative tests. A qualitative test relies on the wearer's subjective response. A quantitative test uses sensitive methods of detection for leakage or malfunction. The procedures in 1910.134 Appendix A Fit Testing Procedures and Appendix B-1 User Seal Check Procedures must be used.

Qualitative fit tests involve a test subject's responding (either voluntarily or involuntarily) to a chemical outside the respirator facepiece. The advantages of this type of testing are:

- it is fast,

- easily performed, and

- uses inexpensive equipment. 
The disadvantages of this type of testing are:

- reproducibility, and

- accuracy may vary.

According to 1910.134, qualitative fit testing may only be used to fit test negative pressure air-purifying respirators that must achieve a fit factor of 100 or less.

Quantitative respirator fit tests involve exposing the respirator wearer to a test atmosphere containing an easily detectable, relatively nontoxic aerosol, vapor, or gas as the test agent and then measuring the penetration of the test agent into the respirator. The advantages of this type of testing are:

- it does not rely on a subjective response, and

- it is much more accurate.

The disadvantages of this type of testing are:

- the cost of instrumentation,

- the need for highly trained personnel to conduct the test,

- use of special respirators equipped with a sampling probe, and

- time.

If the fit factor is equal to or greater than 100 for tight-fitting half facepieces, or equal to or greater than 500 for tight-fitting full facepieces, the quantitative fit test has passed with that respirator.

\section{F. Maintenance and Care of Respirators}

Respirator maintenance and care must be made an integral part of the overall respirator program. Wearing poorly maintained or malfunctioning respirators may be more dangerous than not wearing a respirator at all. The wearer may experience a false sense of security (i.e., feel protected), when in reality, there may be no protection.

\section{Cleaning and Disinfecting}

The employer must provide respirators that are clean, sanitary, and in good working order. The procedures in 1910.134 Appendix B-2 Respirator Cleaning Procedures must be used when cleaning respirators. As an alternative, the manufacturer's cleaning instructions may be used, provided the procedures are as effective as the procedures in Appendix B-2. The respirators must be cleaned at the following intervals: 
- respirators issued for exclusive use (i.e., one person) must be cleaned and disinfected as often as necessary,

- respirators used by more than one employee must be cleaned and disinfected before being worn by different individuals,

- respirators for emergency use must be cleaned and disinfected after each use, and

- respirators used in fit testing and training must be cleaned and disinfected after each use.

2. Storage

Respirators must be stored or packed to prevent deformation of the facepiece and exhalation valve.

All respirators must be stored to protect from:

- damage,

- contamination,

- dust,

- sunlight,

- extreme temperatures,

- excessive moisture, and

- damaging chemicals.

In addition, emergency respirators must be:

- kept accessible to work area,

- stored in compartments or in covers clearly marked, and

- stored in accordance with manufacturer's instructions.

\section{Inspection}

Respirators must be inspected on a regular basis. The employer must ensure that respirators are inspected as follows:

a. Respirators Used in Routine Situations

- must be inspected before each use and during cleaning

b. Respirators Used in Emergency Escape-Only Situations

- must be inspected at least monthly,

- in accordance with manufacturer's instructions, 
- must be check for proper function before and after each use, and

- must be inspected before workplace use.

The employer must ensure that respirator inspections include the following;

c. Inspection Items

- check respirator function,

- check tightness of connections,

- check condition of various part including, but not limited to,

- facepiece,

- head straps,

- valves,

- connecting tube,

- cartridges, canisters or filters, and

- check elastometric part for pliability and sign of deterioration.

\section{d. Self-Contained Breathing Apparatus (SCBA) Inspections}

- inspect SCBAs monthly,

- maintain air and oxygen cylinders in fully charged state,

- recharge when pressure falls to $90 \%$ of manufacturer's recommended pressure level, and

- ensure that regulatory and warning devices function properly.

e. Emergency Escape-Only Respirators

- document inspection,

- date,

- name (or signature) of inspector,

- findings,

- required remedial action,

- serial number (or other means of identifying inspected respirator),

- inspection tag,

- attach to storage compartment, or

- keep with respirator, or

- include in inspection reports as paper or electronic files, and

- maintain until replaced following subsequent inspection.

\section{Repairs}

If a respirator fails an inspection or is otherwise found to be defective, the respirator must be removed from service. The respirator must be repaired or discarded following these procedures: 
- repairs or adjustments made only by persons appropriately trained,

- must use only the manufacturer's NIOSH-approved parts designed for that specific respirator, and

- reducing the admission valves, regulators, and alarms must be adjusted or repaired by the manufacturer or a technician trained by the manufacturer.

\section{H. Respirator Program Evaluation}

According to $29 C F R$ 1910.134, the Respirator Program should be evaluated regularly (e.g., annually), and the written operating procedures should be modified to reflect the evaluation results if necessary. Factors to be assessed include, but are not limited to:

- respirator fit,

- appropriate respirator selection for encountered workplace hazards,

- proper respirator use under workplace conditions employee encounters, and

- proper respirator maintenance.

\section{Respirator Selection}

\section{A. General Requirements}

According to 1910.134 , the employer must select and provide an appropriate respirator to employees based on the respiratory hazards to which the wearer is exposed and the workplace and user factors that affect respirator performance and reliability. Appendix B Non-mandatory Compliance Guidelines for Hazard Assessment and Personal Protective Equipment Selection of 1910.134 should be used to provide compliance assistance. Appendix B will assist the employer in implementing the requirements for a hazard assessment and selection of PPE. The employer must perform the following tasks.

- select NIOSH-certified respirator,

- use in compliance with manufacturer instructions and certifications,

- perform a hazard assessment,

- identify and evaluate respiratory hazards,

- develop a reasonable estimate of employee exposure,

- identify chemical state and physical form, and

- select respirator from number of models and sizes. 


\section{B. Respirators for IDLH Atmospheres}

According to 1910.134(d)(2), the employer must provide the following respirators for employees to use in IDLH atmospheres.

- $\quad$ NIOSH-certified full facepiece pressure demand self-contained breathing apparatus (SCBA),

- with minimum service life of thirty minutes, or

- combination full facepiece pressure demand supplied-air respirator (SAR), - with auxiliary self-contained air supply,

- NIOSH-certified escape only respirator,

- used for escape from IDLH atmosphere (or from atmosphere in which used),

- all oxygen-deficient atmospheres must be considered $\mathrm{DLH}^{*}$.

*EXCEPTION: If the employer demonstrates that under all foreseeable conditions the oxygen concentration can be maintained within specified ranges, then any atmosphere-supplying respirator may be used.

\section{Respirators for Atmospheres That Are NOT IDLH}

According to 1910.134 (d)(3), a respirator must be provided by the employer that is adequate to protect the health of the employee and ensure compliance with all other OSHA statutory and regulatory requirements, under routine and reasonably foreseeable emergency situations. The respirator must be appropriate for the chemical state and physical form of the contaminant.

The employer must provide the following respirators for protection against gases and vapors:

- an atmosphere-supplying respirator, or

- an air-purifying respirator, provided that:

- respirator is equipped with end-of-service-life indicator (ESLI) certified by NIOSH for the contaminant, or

- if no ESLI appropriate for conditions in workplace, employer implements change schedule based on objective information or data.

The employer must provide the following respirators for protection against particulates:

- an atmosphere-supplying respirator, or

- an air-purifying respirator, provided that:

- respirator equipped with NIOSH-certified filter under 30 CFR Part 11 as a high efficiency particulate air (HEPA) filter, or 
- respirator equipped with NIOSH-certified filter for particulates under 42 CFR Part 84 , or

- respirator equipped with NIOSH-certified filter for particulates with mass median aerodynamics diameters (MMAD) of at least 3 micrometers.

\section{Where Can I Go for More Information?}

Listed below are federal regulations (i.e., CFR standards) which must be followed, and recommended or suggested guidelines (e.g., NFPA guidelines) that are not required by federal law. Appendix B of 29 CFR 1910.120 states NFPA standards are to be used as an aid in selecting protective clothing and serve as non-mandatory guidelines to assist employees and employers. However, State and local regulations may specify types of PPE and appropriate levels of protection of specific positions or tasks (e.g., firefighters, emergency medical technicians, hazardous materials management teams, etc.) in dealing with a wide range of hazardous materials. Be familiar with State and local regulations in addition to State OSHA requirements where applicable.

American National Standards Institute (ANSI), American National Standard for Respiratory Protection, ANSI Z88.2-1992.

CFR, Title 29, Part 1910.134, Respiratory Protection.

CFR, Title 30, Part 70, Mandatory Health Standards - Underground Coal Mines.

CFR, Title 29, Part 1910, Occupational Safety and Health.

CFR, Title 40, Part 750, Toxic Substances Control Act.

CFR, Title 10, Part 20, Standards for Protection Against Radiation.

NIOSH (National Institute for Occupational Safety and Health), A Guide to Industrial Respiratory Protection. Cincinnati: U.S. Department of Health, Education, and Welfare, Public Health Service, Centers for Disease Control, 1976, NIOSH publication 76-189.

National Safety Council, Fundamentals of Industrial Hygiene, Third Edition, Barbara Plog, Editor, 1988.

OSHA (Occupational Safety and Health Administration), Inspection Procedures for the Hazardous Waste Operations and Emergency Response Standard, 29 CFR 1910.120 (q): Emergency Response to Hazardous Substances Releases, October 1993, Office of Health Compliance Assistance, Washington, D.C. 
Also included are World Wide Web homepage addresses for various regulatory and other accepted industry wide organizations.

\begin{tabular}{ll}
\hline Agency & \multicolumn{1}{c}{ WWW Address } \\
\hline $\begin{array}{l}\text { Agency for Toxic Substances } \\
\text { and Disease Registry }\end{array}$ & \\
(ATSDR) & http://atsdrl.atsdr.cdc.gov:8080/atsdrhome.html \\
American Conference of & \\
Governmental Industrial & \\
Hygienists (ACGIH) & http://acgih.org/welcome.htm \\
American Industrial & \\
Hygiene Association (AIHA) & http://www.aiha.org/ \\
ANSI & http://www.ansi.org/ \\
Centers for Disease Control (CDC) & http://www.cdc.gov/ \\
CFR & http://www.access.gpo.gov/nara/cfr-table-search.html \\
Environmental Protection & \\
Agency (EPA) & http://www.epa.gov/ \\
Federal Emergency Management & \\
Agency (FEMA) & http://www.fema.gov/ \\
NFPA & http://www.nfpa.org/ \\
NIOSH & http://www.cdc.gov/niosh/homepage.html \\
OSHA & http://www.osha.gov/ \\
3M Racal Health and Safety & http:/www.racal/health.com/index.htm \\
Mine Safety Appliances & http:/www.msanet.com/ \\
Survivair & http://biminic.com/surviv1.htm
\end{tabular}




\section{INFORMATION SHEET ON THE CHEMICAL STOCKPILE EMERGENCY PREPAREDNESS PROGRAM'S (CSEPP) PERSONAL PROTECTIVE CLOTHING}

This information sheet contains different sections, each dealing with one specific piece of the CSEPP recommended personal protective equipment (PPE) ensemble. This ensemble includes the U.S. Army's Battledress Overgarment (BDO) or the Responder suit, chemical protective gloves, a chemical protective hood, chemical protective overshoes, a chemical protective apron (only for workers performing decontamination tasks), a tight fitting, full face, powered air-purifying respirator (PAPR), a loose fitting PAPR, and a ready bag designed to carry all the PPE.

The CSEPP PPE ensemble was selected and recommended by the Centers for Disease Control and Prevention's (CDC) National Center for Environmental Health (NCEH). The NCEH chaired a working group consisting of representatives from the National Institute of Occupational Safety and Health (NIOSH), the Occupational Safety and Health Administration (OSHA), the Federal Emergency Management Agency (FEMA), the U.S. Army, and Argonne National Laboratory. In April, 1994, the Acting Director of the $\mathrm{CDC} / \mathrm{NCEH}$, with the concurrence of NIOSH and OSHA, and subject to certain limitations outlined in Argonne's report, Personal Protective Equipment for Civilian Emergency Workers Following A Chemical Weapons Agent Release, concluded that the use of CSEPP recommended PPE represented a prudent approach to resolving the PPE selection issue.

In December, 1994, Lewis D. Walker, Deputy Assistant Secretary of the Army, sent a letter to Joseph A. Dear, Assistant Secretary for OSHA. The letter requested an evaluation from OSHA regarding the appropriateness of the recommended PPE ensemble for the CSEPP civilian off-site workers in communities located near Tooele Army Depot in Utah.

On July 6, 1995, OSHA responded with an Administrative Interpretation for Tooele, Utah. OSHA stated:

OSHA finds that either the "special" commercially available suits, tested against nerve agent (provided the suits can fit a PAPR) or the BDO suits meet the requirements of 29 Code of Federal Regulations (CFR) 1910.120 (q)(3)(iii) provided the suits are (a) not used in areas in which the level of nerve agent contamination is unknown, or (b) used only in areas in which the level of nerve agent contamination is known to be below the immediately dangerous to life and health (IDLH) level. 
There are a variety of protective clothing and equipment found on the market today. All PPE must meet at a minimum, federal requirements [e.g., all respirators must be approved by NIOSH]. There are other pieces of protective clothing and equipment not identified in this information sheet that would be appropriate for use with chemical warfare agents. The protective clothing and equipment discussed in this information sheet represents PPE appropriate for CSEPP responders, based on CSEPP's concept of operations, equipment testing, work rules, and tasks to be performed.

\section{Who is the Intended Audience?}

The intended audience for this information sheet includes workers who will be wearing CSEPP recommended PPE, and workers who want to increase their basic knowledge and understanding of how PPE provides protection, its limitations, and cost. As this information sheet is intended as an overview of a complex subject, readers are encouraged to consult the references cited herein for additional assistance.

Technical questions regarding the PPE included in this document, and requests for identification of sources through which the items may be obtained, should be directed to:

Commander, U.S. Army Soldier and Biological Chemical Command Project Manager for Chemical Stockpile Emergency Preparedness

Attention: SSBOE-CS

5183 Blackhawk Road

Aberdeen Proving Ground, Maryland 21010-5423

\section{Where Can I Go for More Information?}

More detailed information to aid in the selection of PPE can be obtained from sources such as those listed below.

ACGIH (American Conference of Governmental Industrial Hygienists), 1997.Threshold Limit Values (TLVs) for Chemical Substances and Physical Agents and Biological Exposure Indices (BEIs), Cincinnati: American Conference of Governmental Industrial Hygienists.

ANSI (American National Standards Institute), American National Standard for Respiratory Protection, ANSI Z88.2-1992, New York.

CFR, Title 29, Part 1910.120 Hazardous Waste Operations and Emergency Response (HAZWOPER) Standard. 
CFR, Title 29, Part 1910.120 HAZWOPER Standard, Appendix A - Personal Protective Equipment Test Methods.

CFR, Title 29, Part 1910.120 HAZWOPER Standard, Appendix B - General Description and Discussion of the Levels of Protection and Protective Gear.

CFR, Title 29, Part 1910.120 HAZWOPER Standard, Appendix C - Compliance Guidelines.

CFR, Title 29, Subpart I - Personal Protective Equipment, 1910.132 through 1910.138.

Department of the Army, AR 385-61, Chemical Agent Safety Program, February 1997, Office of the Chief of Staff, Washington, DC.

Department of the Army, DA PAM 385-61, Toxic Chemical Agent Safety Standards, March 1997, Office of the Chief of Staff, Washington, DC.

NFPA (National Fire Protection Association) 1991 - Standard on Vapor-Protective Suits for Hazardous Chemical Emergencies.

NFPA (National Fire Protection Association) 1992 - Standard on Liquid SplashProtective Suits for Hazardous Chemical Emergencies.

NFPA (National Fire Protection Association) 1993 - Standard on Liquid SplashProtective Suits for Non-emergency, Non-flammable Hazardous Chemical Situations.

NIOSH (National Institute for Occupational Safety and Health). Criteria for a Recommended Standard-Occupational Exposure to Hot Environments, Department of Health and Human Services, (NIOSH) Publication No. 86-113. April 1986.

Also included are World Wide Web homepage addresses for various regulatory and other accepted industry wide organizations.

\begin{tabular}{lc}
\hline Agency & WWW Address \\
\hline & \\
Agency for Toxic Substances & \\
and Disease Registry & \\
(ATSDR) & http://atsdrl.atsdr.cdc.gov:8080/atsdrhome.html \\
ACGIH & http://acgih.org/welcome.htm \\
American Industrial Hygiene Association & http://www.aiha.org/ \\
(AIHA) & $8-3$
\end{tabular}


ANSI

Centers for Disease Control and Prevention (CDC)

CFR

Environmental Protection Agency (EPA)

FEMA

NFPA

NIOSH

OSHA

U.S. Army Edgewood Research Development and Engineering Center (ERDEC)

3M Racal Health and Safety

Mine Safety Appliances

Survivair

Kappler

U.S. Army Soldier and Biological Chemical Command (SBCCOM) http://www.ansi.org/

http://www.cdc.gov/

http://www.access.gpo.gov/nara/cfr-table-search.html

http://www.epa.gov/

http://www.fema.gov/

http://www.nfpa.org/

http://www.cdc.gov/niosh/homepage.html

http://www.osha.gov/

http://www.cbdcom.apgea.army.mil/RDA/erdec/risk/ safety/index.html

http:/www.racal/health.com/index.htm

http:/www.msanet.com/

http://biminic.com/survivl.htm

http://www.kappler.com/main.html

http://www.apgea.army.mil 


\subsection{BATTLEDRESS OVERGARMENT (BDO)}

The BDO is currently used by, and manufactured for, the U.S. Army. This suit is a permeable, expendable two-piece overgarment consisting of one coat and one pair of trousers. The coat has a short stand-up collar, a full-length zipper covered by a double protective flap, elastic sleeve closures, and two outer pockets located at chest level. The trousers have a fly front with protective flap, two cargo pockets with flaps, adjustable waist tabs, suspender loops, and zipper closures on the outside of each leg that are covered by protective flaps.

\section{How Does It Work?}

The BDO provides protection against chemical agent vapors and liquid droplets, etiological agents, and toxins.

The overgarment material consists of an outer layer of nylon cotton and an inner layer of charcoal impregnated polyurethane foam. Due to heavy impregnation of charcoal, some charcoal may be deposited on skin and clothing under the protective suit; however, this will not detract from the protective suit's chemical protective characteristics nor harm the wearer.

\section{What Are Its Limitations?}

The $\mathrm{BDO}$ is a limited use garment. The BDO comes sealed in a vapor-barrier bag that protects against rain, moisture, and sunlight. Weartime for the $\mathrm{BDO}$ begins when it is removed from its sealed vapor-barrier bag; therefore, do not remove the $\mathrm{BDO}$ from it sealed vapor-barrier bag until needed. Although the $\mathrm{BDO}$ is not flame resistant, it is water resistant (not waterproof). The BDO is normally worn over clothes; however in high temperature it may be worn over underwear.

The BDO provides a minimum of up to 24 hours of protection against exposure to liquid or vapor chemical agent. When the BDO is removed from its vapor-barrier bag and worn, its protective qualities last for a minimum of 22 days if not exposed to a contaminated environment.

The BDO is not designed to be decontaminated or reimpregnated for reuse. The BDO becomes unserviceable if ripped, torn, if the fastener is broken or missing, or if petroleum, oils, or lubricants are spilled or splashed on the garment. The BDO remains serviceable, even if the vapor-barrier bag suffers damage (pinholes, rips, tears) provided the $\mathrm{BDO}$ has not been physically damaged or exposed to water, petroleum, oils, or 
lubricants, or chemical agents. If damage to the vapor-barrier bag is discovered, seal it as soon as possible. Common duct tape provides an appropriate and expedient way to repair the vapor-barrier bag. Duct tape should be used only on the vapor-barrier bag, not on other personal protective equipment (PPE).

Suits should not be worn if contaminated, punctured, torn, or if signs of abrasion or wear are apparent. Suits which have not been inspected or which are not completely free from such damage should never be put into service. Likewise, never use a suit marked "Training Suit" or "For Training Use Only" in any situation other than training.

The BDO should be stored in a cool, dry area away from direct sunlight. Suits should be removed from service (or designated "Training Use Only") when periodic inspection reveals unsuitability for intended use or after the expiration date.

All PPE have a shelf life which is calculated based on the date of manufacture (printed on the bag). Shelf life, or effective life expectancy, is the period of time the item would offer $100 \%$ protection against exposure to agents. The BDO has a shelf life of 14 years (14 years from the date of manufacture which is printed on the bag).

\section{What Does It Cost?}

The BDO costs approximately $\$ 100$. For more information contact the Commander, U.S. Army Soldier and Biological Chemical Command, Project Manager for Chemical Stockpile Emergency Preparedness, Attention: SSBOE-CS, 5183 Blackhawk Road, Aberdeen Proving Ground, Maryland 21010-5423. 


\subsection{RESPONDER SUIT}

The Responder suit is tough and designed for mobility. The suit is constructed from Responder fabric, which is a multiple layer, film-based composite material. The suit's color is blue.

\section{How Does it Work?}

The Responder provides protection against chemical agent vapors and liquid droplets. The suit consists of coveralls with a zippered front (double storm flaps with velcro closure over the zipper), attached hood, elastic wrists and ankles. The seams are sewn, then strapped for durability and protection.

All seams in the suit are stitched with nylon

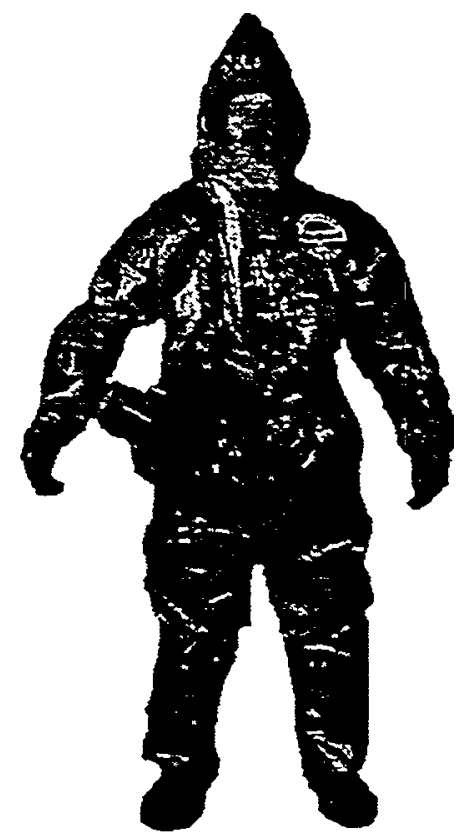
thread and covered with heat sealed tape. The tape used to cover the seams is of a similar composition as the films used in the fabric. Each suit is inspected for quality prior to delivery.

\section{What are Its Limitations?}

The Responder suit is a limited use garment. If the coverall is not contaminated and passes the visual inspection test, the end user may choose to wear the garment again. However, the Responder suit is not designed for multiple wash and decontamination. Suits should not be worn if contaminated, punctured, torn, or if signs of abrasion or wear

- are apparent. Suits which have not been inspected or which are not completely free from such damage should never be put into service. Likewise, never use a suit marked "Training Suit" or "For Training Use Only" in any situation other than training.

The Responder fabric and seams are splash proof (not waterproof) and the cloth zipper is covered with a double overlapping storm flap. To ensure total body splash coverage (e.g., during decontamination procedures), a hood should be worn to protect the neck area between the respirator and zipper opening. The Responder is not flame resistant and should not be worn in intense heat, flames, or in contact with hot surfaces.

The Responder should be stored in a cool, dry area away from direct sunlight. The Responder contains components made from various polymer or rubber materials for which there is no specific shelf life data currently available. Based on the physical 
condition of the suit, it is recommended that downgrading the suit to "Training Use Only" be considered after five years or when periodic inspection reveals the suit inappropriate for intended use.

\section{How Does the Responder Compare with the Battledress Overgarment (BDO)?}

In January, 1996, the Research and Technology Directorate (Edgewood Chemical and Biological Center), Aberdeen Proving Ground, Maryland, U.S. Army Soldier and Biological Chemical Command, released the report, Protection Factor Testing of the Responder Suit. Testing was conducted to measure the capability of the Responder to protect against toxic vapors or aerosols. This was achieved by conducting man-insimulant tests using a challenge of methyl salicylate vapor, a mustard simulant, to measure penetration of vapor into the suit. The standard U.S. Army Battledress Overgarment (BDO) was also included in the test as the baseline. In each trial, the test subjects wore the Responder suit with the full protective ensemble for 30 minutes while performing a series of exercises in a chamber filled with methyl salicylate at a concentration of $50 \mathrm{mg} / \mathrm{m}^{3}$. Vapor concentrations were measured at several locations beneath the suit with passive sampling devices containing the solid absorbent Tenax. Variations in the configuration of the Responder were tested: sleeves taped at the wrists, legs taped at the ankles, and integral foot covers versus no foot covers. In each configuration, the hood of the respirator was tucked into the suit to direct filtered air into the suit.

Results show that the Responder suit provides the highest level of protection when worn with the hood tucked into the suit to direct filtered air into the suit, with wrists taped, and with either ankles taped or integral foot covers. This configuration provides a greater level of protection than the BDO.

\section{What Does it Cost?}

The Responder costs approximately $\$ 75$. For more information contact Kappler USA, P.O. Box 218, Gunthersville, AL 35976. 


\subsection{CHEMICAL PROTECTIVE GLOVES}

The chemical protective gloves protect against liquid chemical agents and vapor hazards. Each glove consists of an outer glove for protection and an inner glove for perspiration absorption. The chemical protective gloves are currently used by, and manufactured for, the U.S. Army.

\section{How Does It Work?}

The outer gloves are made of an impermeable, black, butyl rubber. The inner gloves are made of thin, white cotton.

\section{What Are Its Limitations?}

The glove set is used to protect hands from contamination for a minimum of 14 days if not exposed to a contaminated environment. If the

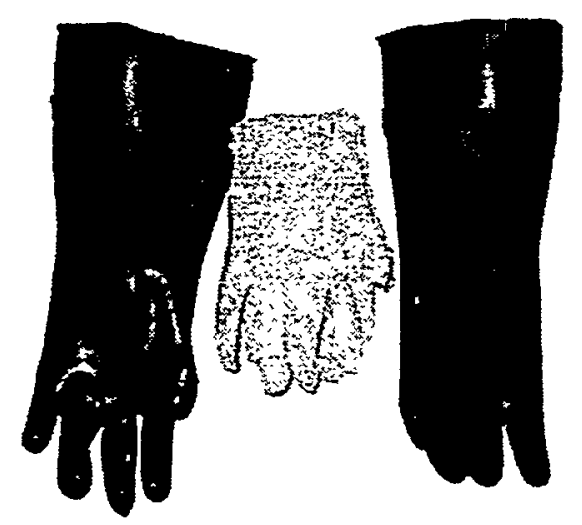
glove set becomes contaminated, replace within 24 hours after exposure. The glove set should be replaced if exposed to any petroleumbased products. The shelf life for the chemical protective gloves is 15 years (15 years from the date of manufacture which is printed on the box containing the gloves).

\section{What Does It Cost?}

The chemical protective gloveset costs approximately $\$ 10$. For more information please contact the Commander, U.S. Army Soldier and Biological Chemical Command, Project Manager for Chemical Stockpile Emergency Preparedness, Attention: SSBOE-CS, 5183 Blackhawk Road, Aberdeen Proving Ground, Maryland 21010-5423. 


\subsection{CHEMICAL PROTECTIVE HOOD}

The chemical protective hood is currently used by, and manufactured for, the U.S. Army.

\section{How Does It Work?}

The hood prevents airborne agents from contaminating the head and neck. The hood was designed by the Army for use with all National Institute of Occupational Safety and Health (NIOSH) approved powered air-purifying respirators (PAPRs). The hood was designed to attach to the facepiece of the respirator.

\section{What Are Its Limitations?}

The hood is used to protect the head and neck from contamination by all known

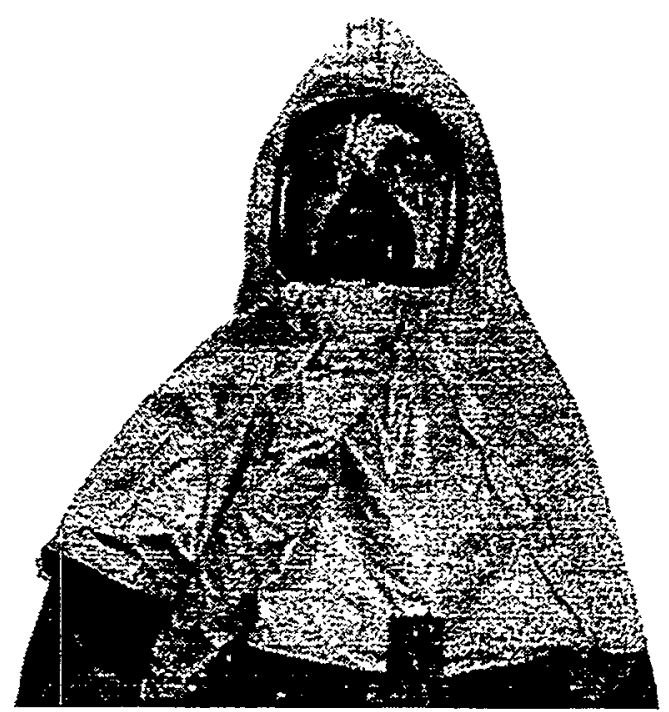
chemical agents. If the hood becomes contaminated, replace within 24 hours after exposure. The hood should be replaced if exposed to any petroleum-based products. The material for the hood is butyl covered cloth. The shelf life for the hood is 5 years ( 5 years from the date of manufacture which is printed on the box containing the hood).

\section{What Does It Cost?}

The hood costs approximately $\$ 26$. For more information please contact the Commander, U.S. Army Soldier and Biological Chemical Command, Project Manager for Chemical Stockpile Emergency Preparedness, Attention: SSBOE-CS, 5183 Blackhawk Road, Aberdeen Proving Ground, Maryland 21010-5423. 


\subsection{CHEMICAL PROTECTIVE OVERSHOES}

The green vinyl overshoe (GVO) is a plain olive drab shoe with elastic fasteners. Closure is accomplished through three elastic "figure 8" fastening loops. The GVOs are currently used by, and manufactured for, the U.S. Army.

\section{How Does It Work?}

The GVO is used to protect feet from contamination by all known agents. The GVO is designed to maintain its protective capabilities for a minimum of 14 days of wear in an uncontaminated environment.

\section{What Are Its Limitations?}

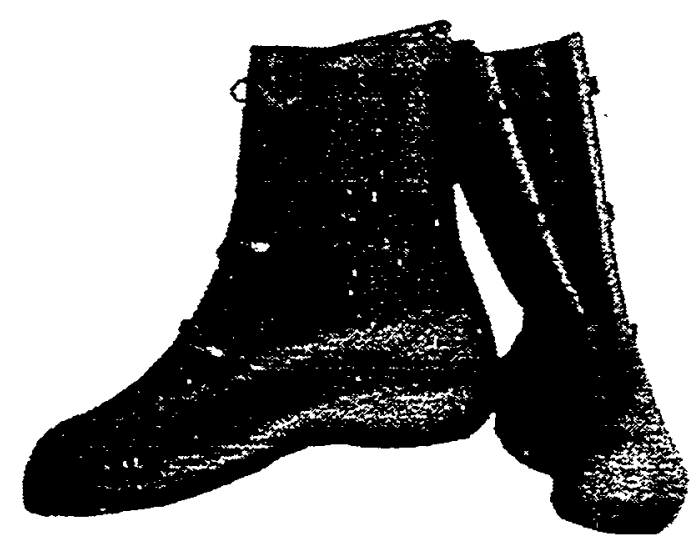

Wearing the GVO provides 12 hours of protection following contamination. If the GVO shows signs of deterioration (e.g., cracks, tears, punctures, or the rubber becomes sticky), replace the overshoes. Inspect GVOs regularly to ensure their integrity is maintained and replace if necessary. The shelf life for the overshoes is 15 years (15 years from the date of manufacture which is printed on the box containing the GVOs).

\section{What Does It Cost?}

The chemical protective GVO costs approximately $\$ 14$. For more information please contact the Commander, U.S. Army Soldier and Biological Chemical Command, Project Manager for Chemical Stockpile Emergency Preparedness, Attention: SSBOE-CS, 5183 Blackhawk Road, Aberdeen Proving Ground, Maryland 21010-5423. 


\subsection{CHEMICAL PROTECTIVE APRON}

Only the emergency workers performing decontamination tasks must wear chemical protective aprons. The chemical protective apron is currently used by, and manufactured for, the U.S. Army.

\section{How Does It Work?}

The apron is made of nylon cloth, coated with butyl rubber on both sides. All sewn seams are cemented and taped to prevent leakage through the needle holes. The apron is a wrap-around style, made of a front panel, two side panels, and raglan sleeves. It is equipped with a neck strap at the top-rear, tie tapes at the middle-rear, and draw tapes on the

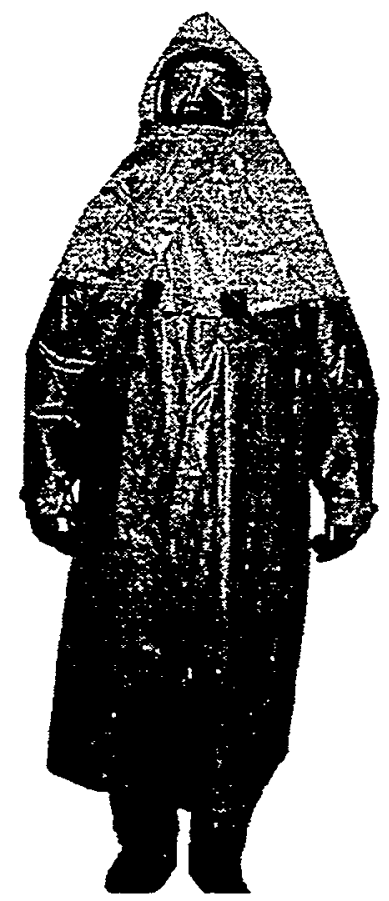
sleeve. The apron is designed to fit loosely and cover the wearer's arms and body from overshoes to neck.

\section{What Are Its Limitations?}

If the apron shows signs of deterioration (e.g., cracks, tears, punctures, or the rubber becomes sticky), replace the apron. Inspect the apron regularly to ensure the integrity is maintained and replace if necessary.

\section{What Does It Cost?}

The chemical protective apron costs approximately $\$ 54$. For more information please contact the Commander, U.S. Army Soldier and Biological Chemical Command, Project Manager for Chemical Stockpile Emergency Preparedness, Attention: SSBOE-CS, 5183 Blackhawk Road, Aberdeen Proving Ground, Maryland 21010-5423. 


\subsection{READY BAG}

The ready bag is a canvas bag designed to carry all the protective equipment (protective suit, hood, gloves, apron, overshoes, PAPR, and chemical detection kit). The ready bag is currently used by, and manufactured for, the U.S. Army.

\section{What Does It Cost?}

The ready bag costs approximately $\$ 24$. For more information please contact the Commander, U.S. Army Soldier and Biological Chemical Command, Project Manager for Chemical Stockpile Emergency

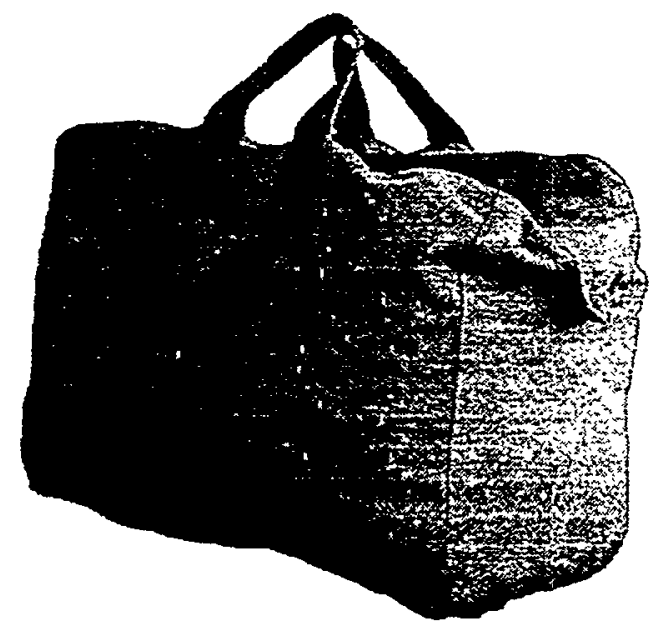
Preparedness, Attention: SSBOE-CS, 5183 Blackhawk Road, Aberdeen Proving Ground, Maryland 21010-5423. 


\subsection{POWERED AIR-PURIFYING RESPIRATOR (PAPR) (Tight Fitting)}

\section{How Does It Work?}

The PAPR uses a battery-operated blower that is designed to deliver essentially decontaminated air at a slight positive pressure into a full facepiece (air pressure in the facepiece is higher than the surrounding air). This means that if a leak occurs, air will flow from inside the facepiece to the outside air. The powered blower draws ambient air through a pair of air-purifying elements (filters or chemical cartridges) which remove specific contaminants and deliver the subsequent air through a corrugated

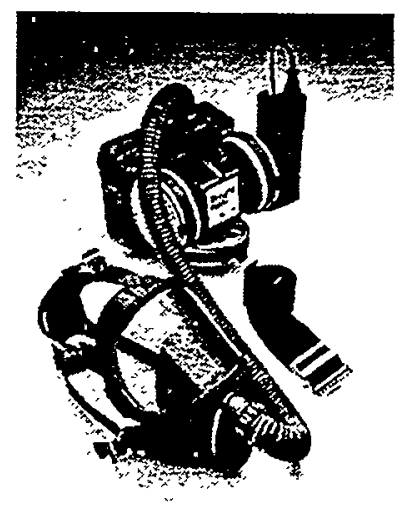
breathing tube into a facepiece assembly on the face of the respirator wearer. Air flow also provides wearer comfort.

\section{What Are Its Limitations?}

- Do NOT use in atmospheres immediately dangerous to life and health (IDLH).

- Do NOT use in atmospheres containing less than 19.5\% oxygen (applicable in confined spaces).

- Do NOT use in flammable or explosive atmospheres.

- Do NOT use as protection against gases or vapors with poor warning properties or those which generate high heats of reaction with sorbent materials in the cartridge/canister. EXCEPTION: There are exceptions to this limitation. A PAPR can be used for protection against gases or vapors with poor warning properties if a cartridge change schedule is implemented based on cartridge service data (provided by Battelle's report).

- Air-purifying elements (filters and chemical cartridges) must not be used beyond their useful life (when they become plugged with particulates or saturated with gases or vapors) or whenever they contribute to increased air flow resistance.

The PAPR does not protect exposed areas of the body. Some contaminants can be absorbed directly through the skin while others may irritate exposed areas. Immediately return to a non-contaminated area if:

- the person can taste or smell contaminants, or if the eyes, nose, or throat become irritated,

- it becomes difficult to breathe,

- the air breathed becomes uncomfortably warm,

- one feels nauseous or dizzy, or

- one notices a decrease or loss of airflow. 


\section{What Does it Cost?}

A PAPR costs approximately $\$ 400-\$ 500$. Please contact the following companies for more information.

3M Racal Health and Safety, 7305 Executive Way, Frederick, MD 21704-8368.

Mine Safety Appliances, P.O. Box 426, Pittsburgh, PA 15230-426.

Survivair Products, 3001 S. Susan Street, Santa Ana, CA 92704. 


\subsection{POWERED AIR-PURIFYING RESPIRATOR (PAPR) (Loose Fitting)}

\section{How Does It Work?}

The hooded or loose fitting respirator uses a battery-operated blower that is designed to deliver essentially decontaminated air at a slight positive pressure into the hood (air pressure in the hood is higher than the surrounding air). This means that if a leak occurs, air will flow from inside the hood to the outside air. The powered blower draws ambient air through a pair of air-purifying element (filters or chemical cartridges) which remove specific contaminants and deliver the subsequent air through a corrugated breathing tube into the hood assembly on the face of the respirator wearer. Air flow also provides wearer comfort.

\section{What Are Its Limitations?}

- Not to be used in atmospheres containing less than $19 \%$ oxygen.

- Not to be used in atmospheres classified as immediately dangerous to life and health

(IDLH) as a result of the following or any other circumstance:

- contaminant concentration

- contaminant identity

- $\quad$ oxygen deficiency

- Wear additional eye protection when required in accordance with the American National Standards Institute (ANSI) Z87.1-1989.

\section{What Are Its Advantages Compared to a Tight Fitting PAPR?}

The advantages of the loose fitting PAPR compared to the tight fitting PAPR are as follows:

- no fit testing requirements,

- no spectacle kits needed,

- do not have to be clean shaven,

- lighter weight, and

- psychological benefit (claustrophobia) 


\section{What Are the Disadvantages Compared to a Tight Fitting PAPR?}

The disadvantages of the loose fitting PAPR compared to the tight fitting PAPR are as follows:

- $\quad$ provides half the protection factor of tight fitting PAPR, and

- $\quad$ if battery/blower failure occurs, wearer has minutes (e.g., 1-3) to exit contaminated area before out of oxygen.

\section{What Does It Cost?}

A loose fitting PAPR costs approximately $\$ 400$ - $\$ 450$. Please contact 3M Racal Health and Safety, 7305 Executive Way, Frederick, MD 21704-8368, for more information. 


\section{INFORMATION SHEET ON CHEMICAL AGENT DETECTION EQUIPMENT FOR FIELD USE}

On December 13, 1994, Lewis D. Walker, Deputy Assistant Secretary of the Army, sent a letter to Joseph A. Dear, Assistant Secretary for the Occupational Safety and Health Administration (OSHA). The letter requested an evaluation from OSHA regarding the appropriateness of the recommended personal protective equipment (PPE) ensemble for the Chemical Stockpile Emergency Preparedness Program's (CSEPP) off-site civilian emergency response workers in communities located near Tooele Army Depot in Utah.

On July 6, 1995, OSHA presented the Army with their Administrative Interpretation of CSEPP's recommended PPE ensemble and requirements. In this Administrative Interpretation, OSHA discussed monitoring requirements. According to OSHA's Interpretation, and following the decision logic from 29 Code of Federal Regulations (CFR) 1910.120 Hazardous Waste Operations and Emergency Response (HAZWOPER) Standard, after any accidental release, and prior to emergency workers entering a contaminated area, or potentially contaminated area, airborne-exposure levels and surface contamination must be measured by the Army. Off-site exposure assessment (i.e., field sampling) must be completed whenever the Army's base perimeter monitoring devices and/or the Army's D2PC plume dispersion model have determined that immediately dangerous to life and health (IDLH) concentrations of chemical agent have extended beyond the geographic borders of the military installation in Tooele, Utah.

Monitoring need only be performed in those geographic areas indicated by base perimeter monitoring devices and/or by the D2PC model. Once identified, these geographic areas must be sampled to establish concentration levels, and resampled periodically until emergency response activities are completed. For those military installations that do not possess base perimeter monitoring devices, it would be prudent to assume any accidental release to have IDLH concentrations reaching beyond the borders of the military installation.

OSHA is also requiring that when emergency responders enter areas wearing powered air-purifying respirators (PAPRs), they must also have adequate monitoring equipment available, unless the area is known not to be contaminated. This equipment must provide a visual or auditory warning prior to the level of contaminant reaching the protection factor of the respirator.

Currently, there are several pieces of detection equipment that would satisfy OSHA's requirements. However, CSEPP has identified and recommended the use of the M256 Series Chemical Agent Detector Kit and has made Real Time Analysis Platforms 
(RTAPs) available to the communities located near military installations where chemical warfare agents are stored. The RTAP satisfies all OSHA requirements. There are other pieces of detection equipment not identified in this information sheet that would be appropriate for use with chemical agents. This information sheet is not meant to be an all inclusive list identifying all the detection equipment that can be used with chemical agents.

This information sheet is in response to general inquiries and questions regarding chemical agent detection equipment. This document contains different sections, each dealing with a specific piece of chemical agent detection equipment. The M256 Kit and the RTAP are the only pieces of detection equipment the U.S. Army has recommended for use in CSEPP. The other pieces of equipment have been included for information purposes only.

\title{
Who is the Intended Audience?
}

The intended audience for this information sheet are those workers (and interested others) who will be wearing CSEPP recommended PPE, and therefore need basic knowledge and understanding of how detection equipment works, its limitations, and cost. As this information sheet is intended as an overview of a complex subject, users are encouraged to consult the references cited herein for additional assistance.

Technical questions regarding the detection equipment included in this document, and requests for identification of sources through which the items may be obtained, should be directed to:

\author{
Commander, U.S. Army Soldier and Biological Chemical Command \\ Project Manager for Chemical Stockpile Emergency Preparedness \\ Attention: SSBOE-CS \\ 5183 Blackhawk Road \\ Aberdeen Proving Ground, Maryland 21010-5423
}

\section{Where Can I Go for More Information?}

More detailed information can be obtained from sources such as those listed below.

ACGIH (American Conference of Governmental Industrial Hygienists), 1997. Threshold Limit Values (TLVs) for Chemical Substances and Physical Agents and Biological Exposure Indices (BEIs), Cincinnati: American Conference of Governmental Industrial Hygienists. 
ANSI (American National Standards Institute), American National Standard for Respiratory Protection, ANSI Z88.2-1992, New York.

CFR, Title 29, Part 1910.120 Hazardous Waste Operations and Emergency Response (HAZWOPER) Standard.

CFR, Title 29, HAZWOPER Standard, Appendix A - Personal Protective Equipment Test Methods.

CFR, Title 29, HAZWOPER Standard, Appendix B - General Description and Discussion of the Levels of Protection and Protective Gear.

$C F R$, Title 29, HAZWOPER Standard, Appendix C - Compliance Guidelines.

CFR, Title 29, Subpart I - Personal Protective Equipment, 1910.132 through 1910.138.

Department of the Army, AR 385-61, Chemical Agent Safety Program, February 1997, Office of the Chief of Staff, Washington, DC.

Department of the Army, DA PAM 385-61, Chemical Agent Safety Standards, March 1997, Office of the Chief of Staff, Washington, DC.

NFPA (National Fire Protection Association) 1991 - Standard on Vapor-Protective Suits for Hazardous Chemical Emergencies.

NFPA (National Fire Protection Association) 1992 - Standard on Liquid SplashProtective Suits for Hazardous Chemical Emergencies.

NFPA (National Fire Protection Association) 1993 - Standard on Liquid SplashProtective Suits for Non-emergency, Non-flammable Hazardous Chemical Situations.

NIOSH (National Institute for Occupational Safety and Health). Criteria for a Recommended Standard-Occupational Exposure to Hot Environments, Department of Health and Human Services, (NIOSH) Publication No. 86-113, April 1986. 
Also included are World Wide Web homepage addresses for various regulatory and other accepted industry wide organizations.

Agency

Agency for Toxic Substances

and Disease Registry

(ATSDR)

ACGIH

AIHA

ANSI

Centers for Disease Control (CDC)

CFR

Environmental Protection

Agency (EPA)

FEMA

NFPA

$\mathrm{NIOSH}$

OSHA

U.S. Army Edgewood Research

Development and Engineering

Center (ERDEC)

Office of the Project Manager

For NBC Defense Systems

U.S. Army Soldier and Biological

Chemical Command (SBCCOM)

\section{WWW-Address}

http://atsdr1.atsdr.cdc.gov:8080/atsdrhome.html

http://acgih.org/welcome.htm

http://www.aiha.org/

http://www.ansi.org/

http://www.cdc.gov/

http://www.access.gpo.gov/nara/cfr-table-search.html

http://www.epa.gov/

http://www.fema.gov/

http://www.nfpa.org/

http://www.cdc.gov/niosh/homepage.html

http://www.osha.gov/

http://www.cbdcom.apgea.army.mil/RDA/erdec/risk/ safety/index.html

http://www.cbdcom.apgea.army.mil/RDA/

pmnbc/index.html

http://www.apgea.army.mil 


\subsection{INDIVIDUAL CHEMICAL AGENT DETECTOR (ICAD)}

The Individual Chemical Agent Detector (ICAD) detects nerve agents (GA, GB, and $\mathrm{GD}$, to $0.5 \mathrm{mg} / \mathrm{m}^{3}$ ) and blister agents $\left(\mathrm{H}\right.$, to $\left.10.0 \mathrm{mg} / \mathrm{m}^{3}\right)$. The ICAD does not detect agent levels down to the 8 hour time weighted average (TWA) for nerve and blister agents. The ICAD is about the size of an identification badge and, like a badge, it is made to be worn on the outside of protective clothing.

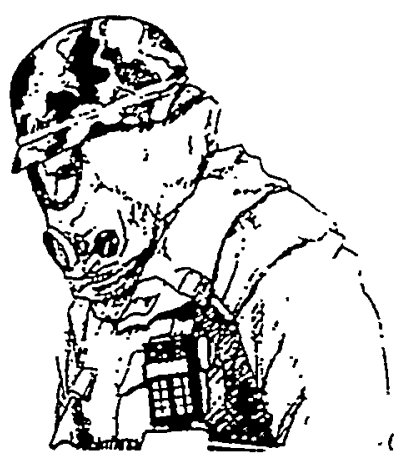

\section{How Does It Work?}

The ICAD includes two electrochemical sensors, each of which is covered by a thin diffusion membrane. One sensor is sensitive to nerve agents and the other sensor detects blister agents. Chemical agents in the air diffuse through the membranes on the faces of the ICAD sensors, and are collected by the electrolyte behind the membranes. The chemical agent concentrations in the electrolyte are measured by multiple-electrode electrochemical sensor systems. When the concentration reaches a preset threshold level, an audio alarm sounds and a light-emitting diode comes on.

\section{What Are Its Limitations?}

The ICAD does not detect nerve agent VX. Also, the ICAD does not detect down to the immediately dangerous to life and health (IDLH) level for blister agents (proposed IDLH value for $\mathrm{H}$ is $1.67 \mathrm{mg} / \mathrm{m}^{3}$ ).

The ICAD cannot be stored or operated at temperatures below or above the operating temperature range ( 0 to 113 degrees $F$ ). To do so could cause permanent damage to the ICAD.

\section{What Does It Cost?}

The ICAD roughly costs approximately $\$ 1,000-\$ 2,000$. For more information please contact the Commander, U.S. Army Soldier and Biological Chemical Command, Project Manager for Chemical Stockpile Emergency Preparedness, Attention: SSBOE-CS, 5183 Blackhawk Road, Aberdeen Proving Ground, Maryland 21010-5423. 


\subsection{IMPROVED CHEMICAL AGENT MONITOR (ICAM)}

The ICAM responds to nerve and blister agents vapors down to the following concentrations: G-series $0.03 \mathrm{mg} / \mathrm{m}^{3}, \mathrm{~V}$-series $0.1 \mathrm{mg} / \mathrm{m}^{3}, \mathrm{H}$ series $0.1 \mathrm{mg} / \mathrm{m}^{3}$. The ICAM does not detect agent levels down to the 8 hour time weighted average (TWA) for nerve or blister agents. The ICAM is approximately the size and weight of a camcorder. The ICAM is an improved version of the chemical agent monitor (CAM). Only the ICAM will be

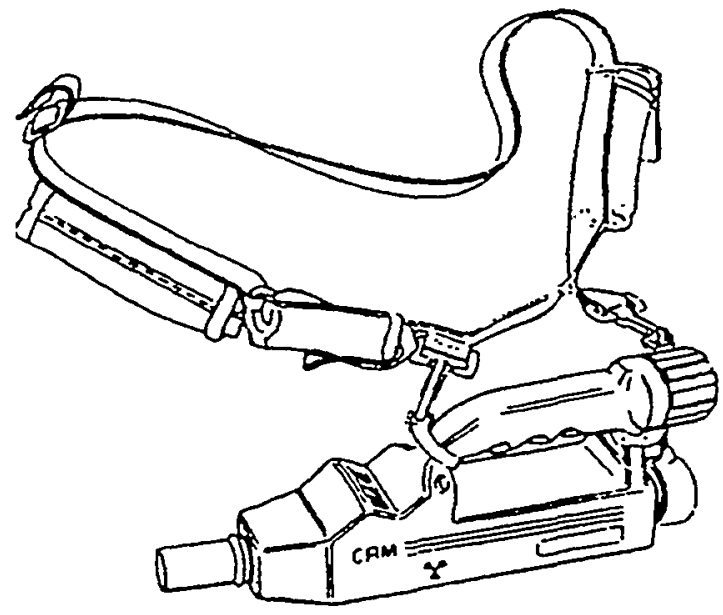
discussed.

\section{How Does It Work?}

The ICAM has a display which shows the readings and corresponding warning for three levels. The first level indicates a low hazard; the second level indicates a high hazard; and the third level indicates a very high hazard.

\section{What Are Its Limitations?}

The readings do not indicate what the level of contamination is - only a low, high, or very high hazard. The ICAM operator must manually switch modes in order to detect nerve ( $\mathrm{G}$ and VX) or blister $(\mathrm{H})$ agents. The ICAM cannot detect both agents at the same time. Also, the ICAM contains a beta radiation source. This radioactive source is totally enclosed and protected by the ICAM case and poses no hazard when intact. However, the ICAM is potentially dangerous if broken.

The ICAM is a point monitor and cannot give a realistic assessment of the area-wide vapor hazard from a single position. A point detector can only measure contamination at one point or location (i.e., can only measure contamination at the front of the nozzle assembly). Also, there are vapors present in the atmosphere that can, in some circumstances, give a false response. The situations most likely to result in a false response involve sampling in enclosed spaces or sampling near strong vapor sources (e.g., smoke and fumes, cleaning compounds, and aromatic vapors). Included in this group of materials are perfumes and food flavorings (e.g., aftershaves, perfumes, peppermints, cough lozenges, and menthol cigarettes), as well as cleaning compounds 
and disinfectants, such as menthol and methyl salicylate, containing additives giving them a pleasant smell.

\section{What Does It Cost?}

The ICAM costs approximately $\$ 6,000-\$ 6,500$. For more information please contact the Commander, U.S. Army Soldier and Biological Chemical Command, Project Manager for Chemical Stockpile Emergency Preparedness, Attention: SSBOE-CS, 5183

Blackhawk Road, Aberdeen Proving Ground, Maryland 21010-5423. 


\subsection{M256 SERIES CHEMICAL AGENT DETECTOR KIT}
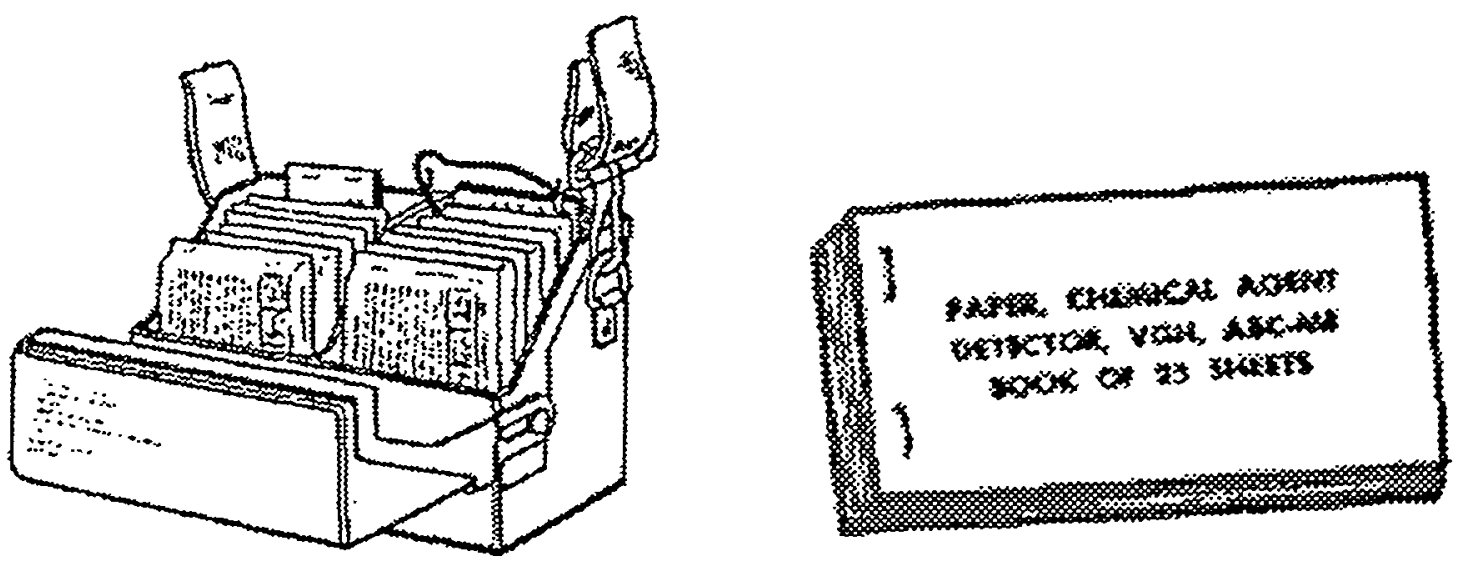

The M256 series Chemical Agent Detector Kit is capable of detecting both liquid and vapor concentrations of chemical weapons agents. The M256 Detector Kit is used primarily to determine if there is a chemical agent present, and the type of chemical agent present. The M256 Kit should not be used for monitoring or warning. Rather, after an alarm sounds and workers have donned their personal protective equipment (PPE), these kits can be used to determine if the initial alarm was true and chemical weapons agents have contaminated the area.

The M256 series contains:

- 12 individually packaged samplers/detectors,

- a set of instruction cards, and

- a packet of ABC-M8 VGH chemical agent detector paper.

\section{How Does It Work?}

The samplers/detectors come packaged as liquid-filled ampoules in a small, compact, plastic case. Each sampler/detector detects harmful vapor concentrations of nerve, blister, or blood agents. When the ampoules are crushed between the fingers, they form channels which ensure the test spots are wet. Each test spot develops a distinctive color which indicates whether a chemical agent is or is not present in the air. Each test spot detects chemical agents in the following concentrations - nerve (G series $0.005 \mathrm{mg} / \mathrm{m}^{3}$, $\mathrm{VX} 0.02 \mathrm{mg} / \mathrm{m}^{3}$ within 15 minutes), and blister (H $12 \mathrm{mg} / \mathrm{m}^{3}$ within 10 minutes). 
Each M256 Kit contains a booklet of ABC-M8 VGH chemical agent detector paper. Each booklet contains 25 sheets of paper. The paper detects and identifies liquid agents (liquid V-or G-type nerve agents or H-type blister agents). This paper turns colors when the paper touches a chemical agent. The paper is used by blotting it on the suspected : contaminated surface.

- V-type nerve agent turns the paper dark green,

- G-type nerve agent turns it yellow, and

- H-type blister agent turns it red.

\section{What Are Its Limitations?}

Arctic weather affects the packaged samplers/detectors kit. When the temperature is $15^{\circ} \mathrm{F}\left(-21^{\circ} \mathrm{C}\right)$ or below, the kit can give inaccurate indications. Solutions in the capsules freeze, and the solutions will not work even if reheated. Care should be taken to keep the kit at a temperature above freezing. Night operations cause problems when using the samplers/detectors. The sampler/detector must be read in white light.

Night operations cause problems when using ABC-M8 paper. The paper must also be read in white light. Do not rub the M8 paper against the surface because false positive (red) streaks are produced. Also, M8 paper cannot detect liquid that is frozen. If the substance is thickened or frozen, a sample is collected with a stick or scraper and wiped onto a sheet of M8 paper. The sample is placed on a heated surface, such as an operating vehicle or a power generator, to stimulate thawing of the suspected agent so that identification is expedited. Because of off-gassing, this procedure should not be performed inside a heated vehicle or enclosed space.

\section{What Does It Cost?}

The Kit costs around \$50. For more information please contact the Commander, U.S. Army Soldier and Biological Chemical Command, Project Manager for Chemical Stockpile Emergency Preparedness, Attention: SSBOE-CS, 5183 Blackhawk Road, Aberdeen Proving Ground, Maryland 21010-5423. 


\subsection{REAL TIME ANALYSIS PLATFORM (RTAP)}

The RTAP is a self-contained mobile platform that can be moved from site to site and is typically housed in a van or truck. It is a mobile, low level monitor designed to respond to nerve agents $\left(0.0001 \mathrm{mg} / \mathrm{m}^{3}\right.$ for $\mathrm{GB}$, and 0.00001 $\mathrm{mg} / \mathrm{m}^{3}$ for $\left.\mathrm{VX}\right)$, and blister agents $(0.003$ $\mathrm{mg} / \mathrm{m}^{3}$ for mustard) in less than 15 minutes with alarm capability. The RTAP is especially useful in on-site clearance of igloos and other suspect agent contamination sites. The RTAP does detect agent levels down to the 8 hour TWA for nerve and blister agents.

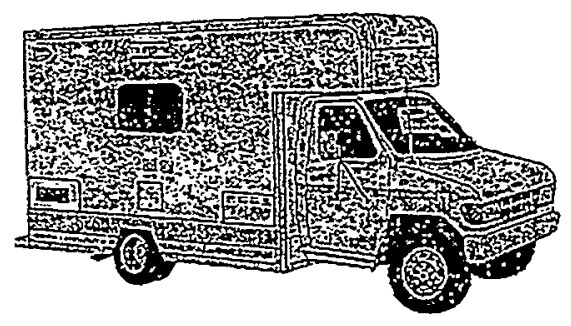

\section{How Does It Work?}

The RTAP combines a gas chromatograph with an automatic continuous environmental monitoring system that collects compounds on a solid sorbent trap, thermally desorbs them into a capillary gas chromatography column, and detects the compounds with a simultaneous phosphorous and sulfur dual-headed flame photometric detector.

The Dynatherm 900 Automatic Continuous Environmental Monitor (ACEM) is the component that does the analysis. The Hewlett-Packard 5890 is the component that provides a continuous readout. There is both an audible and visible alarm. The RTAP has a response time of approximately 15 minutes. Depots are using the mobile vans in their day-to-day operations.

\section{What Are Its Limitations?}

Common interferences with detectors such as the RTAP which may result in a false response are chlorine, $\mathrm{CHE}$ inhibitors such as insecticides, vehicle exhaust, and acid vapors. Mass spectrometers are available which can reduce the effect of interferences.

\section{What Does It Cost?}

The RTAP costs varies based upon the contract and components specified. The RTAP can range from approximately $\$ 150,000$ to $\$ 350,000$. For more information please contact the Commander, U.S. Army Soldier and Biological Chemical Command, Project Manager for Chemical Stockpile Emergency Preparedness, Attention: SSBOE-CS, 5183 Blackhawk Road, Aberdeen Proving Ground, Maryland 21010-5423. 


\subsection{FOX, XM93, NBC RECONNAISSANCE SYSTEM (NBCRS)}

The FOX M93Al a fully integrated nuclear, biological, and chemical (NBC) reconnaissance system is a six wheel, amphibious armored cargo and tactical transport vehicle powered by a V8 diesel engine (320 horse power). The maximum speed is 65 miles per hour with a cruising range of 500 miles. It weights 18.7 tons combat

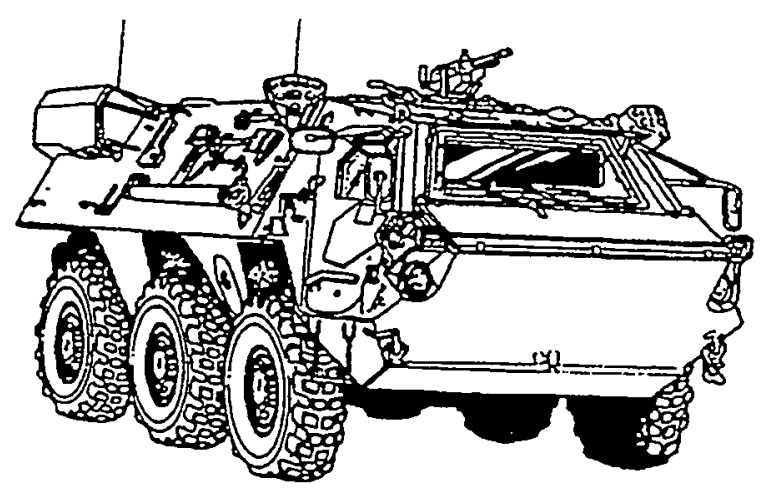
loaded and 16.9 tons without the crew and ammunition. It is equipped with a $40 \mathrm{~mm}$ smoke grenade launcher and an M240E1, $7.62 \mathrm{~mm}$ machine gun. The FOX is also equipped with a collective protection system which keeps the crew's working area free from contamination.

\section{How Does It Work?}

The integrated NBC defense/detection system has four key components.

- Mobile Mass Spectrometer (MM1) - Consists of a detection membrane probe system with an air/ground probe, and a rugged microprocessor. The system can monitor and identify all known chemical agents.

- $\quad$ Radiac Equipment (ASGI) - Consists of two probes installed in the exterior ports on each side of the vehicle connected to the radiation detection, identification, and computation instrument/recorder inside the vehicle.

- Vehicle Orientation System (VOS-25) - Operates through the principles of gyroscopic motion with a motion sensor attached to the vehicle's transmission. The unit (VOS-25) is integrated with the radiation equipment (ASGI) and the chemical detection system (MM1) and can display chemical and radiological contamination on a map with the push of a button.

- $\quad$ NBC marking equipment - The vehicle has an NBC Marking Kit with an air-lock (glove port) through which the NBC contamination marking buoys are positioned.

The FOX has nuclear, chemical and biological sampling equipment that consists of:

- A sample collecting device with transport container.

- Glove (rubber) protection for collecting samples. The equipment is fixed outside the vehicle and is operated manually using the glove and glove port device. 
The FOX is also protected against electromagnetic pulse (EMP), transient radiation effects on electronics (TREE), and electronic countermeasure (ECM).

\section{What Are Its Limitations?}

Common interferences with detectors such as the FOX which may result in a false response are chlorine, $\mathrm{CHE}$ inhibitors such as insecticides, vehicle exhaust, and acid vapors.

\section{What Does It Cost?}

The FOX costs approximately $\$ 2,000,000$. For more information please contact the Commander, U.S. Army Soldier and Biological Chemical Command, Project Manager for Chemical Stockpile Emergency Preparedness, Attention: SSBOE-CS, 5183

Blackhawk Road, Aberdeen Proving Ground, Maryland 21010-5423. 


\subsection{MINIATURE CONTINUOUS AIR MONITORING SYSTEM (MINICAMS)}

The MINICAMS is a flexible, expandable system developed specifically for the detection of all common chemical warfare agents, simulants, and related compounds. MINICAMS is an automatic continuous air monitoring system using gas chromatography to monitor for the presence of chemical warfare agents, simulants and related compounds over a wide range of concentrations. MINICAMS may be purchased in one of three configurations (Field, Fixed-Site, and Laboratory). The Field MINICAMS is the most appropriate configuration for emergency response and will be discussed below. Although MINICAMS alone can meet most monitoring needs, a wide assortment of

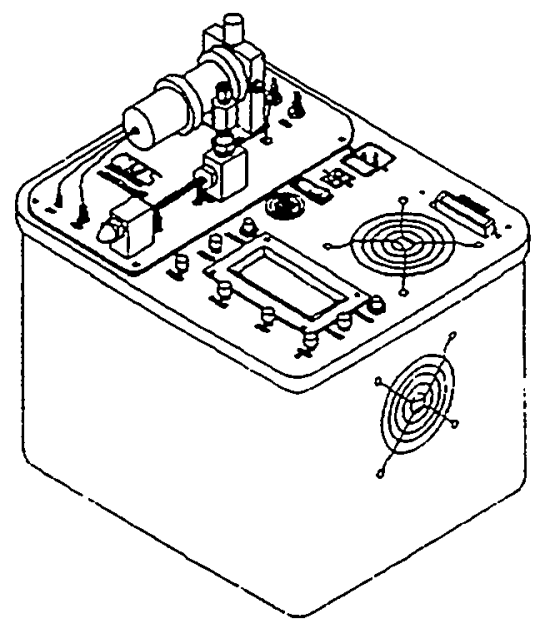
accessories are offered so that applications of the MINICAMS can be extended to almost any sampling environment.

The Automatic Continuous Air Monitoring System (ACAMS) is a type of automated gas chromatography that is available for near real-time agent detection and alarm capability at various levels. MINICAMS is the new generation of monitoring equipment that began with the ACAMS analytical system and has now evolved into a more powerful monitoring system for chemical agents.

\section{How Does It Work?}

The Field MINICAMS automatically collects an air sample, performs an analysis, and reports the results. Many operating parameters can be changed conveniently by the operator to meet site-specific requirements. Once the parameters are changed, the system continues to operate automatically until the operator intervenes.

The solid-sorbent sampling configuration is a sophisticated analytical and alarm system based on the concentration of agents and simulants from a large volume of air using solid-sorbent collection. Components in the sample are separated using temperatureprogrammed, capillary gas chromatography and detected using a choice of a flamephotometric detector, flame-ionization detector, or a photoionization detector. The flame-photometric detector is normally used for chemical agent monitoring. However, other detector combinations are also available for the determination of other classes of 
compounds. The solid-sorbent sample collection provides the sensitivity necessary to determine the chemical agents at the 8 hour time weighted average (TWA) concentrations, which range from $0.00001 \mathrm{mg} / \mathrm{m}^{3}$ for $\mathrm{VX}$ to $0.003 \mathrm{mg} / \mathrm{m}^{3}$ for agent $\mathrm{HD}$. Applications using the solid-sorbent configuration include TWA level monitoring to protect workers from exposure to chemical agents and other monitoring tasks requiring measurement of agents, simulants, and related compounds at extremely low concentrations.

MINICAMS consists of an instrument controller and a sampling and analytical system, also called a monitor. The monitor performs the chemical analysis. The controller contains the microprocessor and software which controls operation of the monitor.

The Field MINICAMS offers several advantages including:

- all monitor and controller components are in one chassis,

- can sample sequentially at up to 12 different locations (400-600 feet away),

- $\quad$ smallest and lightest MINICAMS,

- $\quad$ easiest to relocate and most suitable for mobile applications, and

- monitors for up to eight compounds simultaneously.

\section{What Are Its Limitations?}

A common interference with detectors such as the MINICAMS which may result in a false alarm is the presence of high concentrations of hydrocarbons, such as concentrated diesel exhaust fumes. However, a chlorine-selective detector (XSD) and a dual detector (FPD/FID) are available to reduce interferences.

\section{What Does It Cost?}

The Field MINICAMS costs approximately $\$ 25,000$. For more information, please contact CMS Field Products Group, O.I. Analytical, 200 Chase Park South, Suite 100, Birmingham, AL 35244. 


\subsection{M8A1 AUTOMATIC CHEMICAL AGENT ALARM (ACAA)}

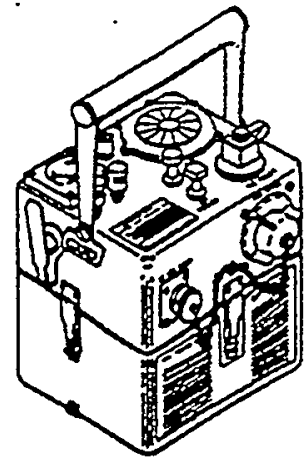

M43A1 Detector

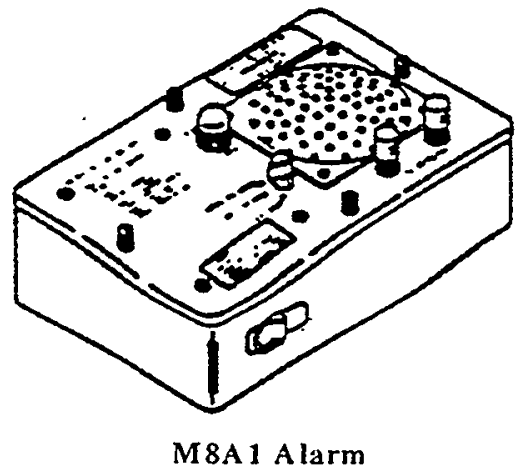

The M8A1 ACAA is a remote continuous air sampling alarm used by the Army. This alarm samples air for the presence of nerve agent vapors (GA, GB, and GD) and nerve agent aerosols (i.e., VX).

\section{How Does It Work?}

The M8A1 alarm is a portable/fixed alarm using the M43Al detector. The ACAA is commonly used by troops to guard their perimeter, however, it has also been used in fixed facilities such as Mobile Army Surgical Hospital (MASH) units. The M43A1 detector is capable of detecting nerve agent concentrations as low as $0.2 \mathrm{mg} / \mathrm{m}^{3}$ for $\mathrm{GB}$ and $0.4 \mathrm{mg} / \mathrm{m}^{3}$ for $\mathrm{VX}$. The alarms are placed throughout a region (or facility) so as to maximize warning if nerve agent vapor is detected.

\section{What Are Its Limitations?}

The ACAA can only be used to detect nerve agents. The ACAA does not detect blister agents. Also, the ACAA does not detect nerve agent down to the 8 hour time weighted average (TWA), rather immediately dangerous to life and health (IDLH) levels.

During the war in the Persian Gulf, ACAAs experienced a high frequency of false alarms. Two principle causes were identified as high temperatures and dust concentrations in the air. 


\section{What Does it Cost?}

The M8A1 ACAA costs approximately $\$ 2,000$ to $\$ 3,000$. For more information, please contact the Commander, U.S. Army Soldier and Biological Chemical Command, Project Manager for Chemical Stockpile Emergency Preparedness, Attention: SSBOE-CS, 5183 Blackhawk Road, Aberdeen Proving Ground, Maryland 21010-5423 
ORNL/TM-13343

\section{DISTRIBUTION}

\section{INTERNAL}

1. G. E. Courville

2. T. R. Curlee

3-32. Cheri B. Foust

33. H. Hardee

34. R. R. Lee

\author{
35. R. B. Shelton \\ 36. J. H. Sorensen \\ 37. B. M. Vogt \\ 38. Central Research Library \\ 39. Lab Records-RC \\ 40-41. Lab Records (OSTI)
}

\section{EXTERNAL}

42. Lilia A. Abron, President, PEER Consultants, P.C., 1460 Gulf Blvd., $11^{\text {th }}$ Floor, Clearwater, FL 34630

43. Dr. Susan L. Cutter, Professor and Chair, Director, Hazards Research Lab, Department of Geography, University of South Caroline, Columbia, South Carolina 29208

44. Randy Devault, U.S. Department of Energy, Oak Ridge,.TN

45. Thomas E. Drabek, Professor, Department of Sociology, University of Denver, Denver, CO 80208-0209

46. Dr. Stephen G. Hildebrand, Director, Environmental Sciences Division, Oak Ridge National Laboratory, Post Office Box 2008, Oak Ridge, Tennessee 378316037

47. Dr. Dennis Mileti, Natural Hazards Center, Campus Box 482, University of Colorado, Boulder, CO 80309-0482

48. P. Richard Rittlemann, FAIA, Executive Vice President, Burt Hill Kosar Rittleman Associates, 400 Morgan Center, Butler, PA 16001-5977

49. Susan F. Tierney, The Economic Resource Group, Inc., One Mifflin Place, Cambridge, MA 02138

50. C. Michael Walton, Ernest H. Cockrell Centennial Chair In Engineering and Chairman, Department of Civil Engineering, University of Texas at Austin, Austin, TX 78712-1076

51-52. Office of Assistant Manager of Energy \& Development, P.O. Box 2001, Oak Ridge, TN 37831-6269 